Supporting Information

\title{
Bimetallic Bis-anion Cascade Complexes of Magnesium in Nonaqueous Solution
}

David Van Craen ${ }^{\dagger}$ Ian G. Flynn ${ }^{\dagger}$, Veronica Carta ${ }^{\dagger}$, Amar H. Flood ${ }^{*}, \dagger$

${ }^{\dagger}$ Department of Chemistry, Indiana University, Bloomington, IN 47405-7102, United States

*E-mail: aflood@indiana.edu 


\section{$\underline{\text { Table of Contents }}$}

1. Materials and Methods 3

2. Synthetic Procedures 3

3. Magnesium Binding Studies

3.1 Magnesium binding with $\mathbf{L}^{\mathbf{D P A}}-\mathrm{H}$

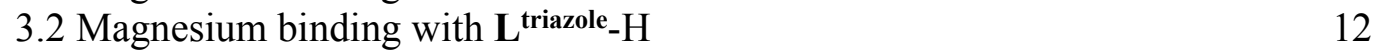

$\begin{array}{ll}\text { 3.3 Magnesium binding with } \mathbf{L}^{\text {furan }}-\mathrm{H} & 14\end{array}$

$\begin{array}{ll}\text { 3.4 Magnesium binding with } \mathbf{L}^{\text {thiophene }}-\mathrm{H} & 16\end{array}$

$\begin{array}{ll}\text { 3.5 Magnesium binding with } \mathbf{L}^{\mathbf{M e}}-\mathrm{H} & 18\end{array}$

3.6 Magnesium binding with $\mathbf{L}^{\mathbf{E t}}-\mathrm{H} \quad 20$

3.7 Magnesium binding with $\mathbf{L}^{\mathbf{i P r}}-\mathrm{H} \quad 22$

3.8 Magnesium binding with $\mathbf{L}^{\mathbf{B z}}-\mathrm{H} \quad 25$

3.9 Anion exchange for $\left[\mathbf{L}^{\mathbf{D P A}} \mathrm{Mg}_{2}\left(\mu_{2}-\mathrm{NO}_{3}\right)_{2}\right]^{+}$with (TBA)OAc 27

3.10 Anion exchange for $\left[\mathbf{L}^{\text {DPA }} \mathrm{Mg}_{2}\left(\mu_{2}-\mathrm{NO}_{3}\right)_{2}\right]^{+}$with $(\mathrm{TBA}) \mathrm{H}_{2} \mathrm{PO}_{4} \quad 32$

3.11 Anion exchange for $\left[\mathbf{L}^{\mathbf{D P A}} \mathrm{Mg}_{2}\left(\mu_{2}-\mathrm{NO}_{3}\right)_{2}\right]^{+}$with $(\mathrm{TBA})_{3} \mathrm{HP}_{2} \mathrm{O}_{7} \quad 35$

3.12 IR spectra of the magnesium complexes of $\mathrm{L}^{\mathrm{DPA}}$ and $\mathrm{L}^{\mathrm{Et}} 36$

4. ESI Mass Spectrometry for the Bimetallic Magnesium Complexes 37

5. NMR Spectra of Compounds 45

6. Reports for Crystal Structures 59

$\begin{array}{ll}\text { 7. References } & 70\end{array}$ 


\section{Materials and Methods}

Reagent grade bulk solvents used for purification are purchased from Macron Fine Chemicals, VWR and Fisher Chemical. Chloroform (stabilized with amylene, HPLC grade) was obtained from Oakwood Chemical and tetrahydrofuran (inhibitor-free) from Sigma-Aldrich. 4-Bromophenol and iminodiacetic acid procured from Oakwood Chemical. Dipicolylamine purchased from AK Scientific and bis(furan-2-ylmethyl)amine as well as bis(thiopen-2-ylmethyl)amine obtained from Enamine. Methanol (anhydrous) and hydrochloric acid obtained from Macron Fine Chemicals. Ethanol (anhydrous) procured from Pharmaco. Isopropanol, triethylamine and glacial acetic acid sourced from MilliporeSigma. Trifluoroacetic acid is obtained from Fisher Chemical. Benzyl alcohol, azidobenzene solution ( $0.5 \mathrm{M}$ in 2-methyltetrahydrofuran), dipropargylamine, $p$-toluenesulfonic acid, thionyl chloride, hydrogen bromide solution (33 wt\% in acetic acid), lithium aluminium hydride, 1,8diazabicyclo[5.4.0] undec-7-ene (DBU), (+)-sodium L-ascorbate, tetrabutylammonium acetate, and tris(tetrabutylammonium) hydrogen pyrophosphate purchased from Sigma-Aldrich. Hexamethylenetetramine, magnesium(II) nitrate hexahydrate and tetrabutylammonium dihydrogen phosphate obtained from Alfa Aesar. Deuterated solvents procured from Cambridge Isotope Laboratories. Silicagel (40 - $63 \mu \mathrm{m}$, ZEOprep 60 ECO) sourced from ZEOCHEM. The reagents and solvents were used without further purification.

Automated column chromatography performed at a Biotage Isolera One device. Columns filled with ZEOprep 60 ECO silicagel were prepared and repacked with new silicagel for each compound. NMR spectroscopy was measured using a Varian Inova i400, i500 and i600, and high resolution mass spectrometry was carried out at a Thermo LTQ-Orbitrap XL.

Binding studies were performed in $5 \mathrm{mM}$ acetonitrile- $d_{3}$ solutions at $25{ }^{\circ} \mathrm{C}$ and measured at the $600 \mathrm{MHz}$ Varian Inova i600. The studies were performed dilution corrected. First, $5 \mathrm{mM}$ solutions of the corresponding ligands in acetonitrile- $d_{3}$ were prepared. An aliquot of these solutions was used to dissolve an excess of magnesium(II) nitrate hexahydrate. These ligand / salt solutions were then added stepwise to the solutions consisting of only ligands so that the concentration of the ligands is exactly $5 \mathrm{mM}$ at any time in the titration while the amount of magnesium salt increases.

\section{Synthetic Procedures}

5-Bromo-2-hydroxyisophthalaldehyde (2): The compound was synthesized according to the literature procedures. ${ }^{1-2}$ Yellow needles $(37 \%, 91.4 \mathrm{mmol}, 20.9 \mathrm{~g})$. ${ }^{1} \mathbf{H}$ NMR $\left(500 \mathrm{MHz}, 25^{\circ} \mathrm{C}, \mathrm{CDCl}_{3}\right): \delta=11.53\left(\mathrm{~s}, 1 \mathrm{H}, \mathrm{H}_{\mathrm{c}}\right), 10.19(\mathrm{~s}, 2 \mathrm{H}, \mathrm{Hb}), 8.05(\mathrm{~s}$, $\left.2 \mathrm{H}, \mathrm{H}_{\mathrm{a}}\right) \mathrm{ppm}$. The NMR spectrum matches reported values and the compound was used after one recrystallization.

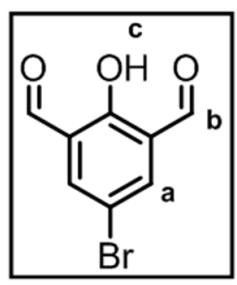

(5-Bromo-2-hydroxy-1,3-phenylene)dimethanol (3): The compound was synthesized according to literature procedures. ${ }^{1}$ Pale yellow solid $(87 \%, 22.8 \mathrm{mmol}$, $5.31 \mathrm{~g}) .{ }^{1} \mathrm{H}$ NMR $\left(500 \mathrm{MHz}, 25^{\circ} \mathrm{C}, \mathrm{DMSO}-d_{6}\right): \delta=8.74\left(\mathrm{~s}, 1 \mathrm{H}, \mathrm{H}_{\mathrm{d}}\right), 7.29\left(\mathrm{~s}, 2 \mathrm{H}, \mathrm{H}_{\mathrm{a}}\right)$, $5.30\left(\mathrm{~m}, 2 \mathrm{H}, \mathrm{H}_{\mathrm{c}}\right), 4.51(\mathrm{~d}, J=3.6 \mathrm{~Hz}, 4 \mathrm{H}, \mathrm{Hb}) \mathrm{ppm}$. The NMR spectrum matches the reported values and the compound was used without further purification.

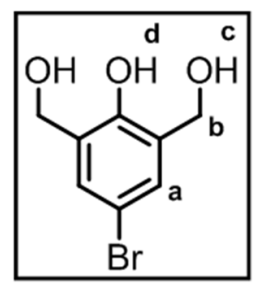


4-Bromo-2,6-bis(bromomethyl)phenol (4): The compound was synthesized according to literature procedure. ${ }^{3}$ Colorless solid $(83 \%, 8.30 \mathrm{mmol}, 2.98 \mathrm{~g})$. ${ }^{1} \mathbf{H}$ NMR $\left(500 \mathrm{MHz}, 25^{\circ} \mathrm{C}, \mathrm{CDCl}_{3}\right): \delta=7.40\left(\mathrm{~s}, 2 \mathrm{H}, \mathrm{H}_{\mathrm{a}}\right), 5.59\left(\mathrm{~s}, 1 \mathrm{H}, \mathrm{H}_{\mathrm{c}}\right), 4.49(\mathrm{~s}, 4 \mathrm{H}$, $\left.\mathrm{H}_{\mathrm{b}}\right) \mathrm{ppm}$. The NMR spectrum matches reported values and the compound was used without further purification.

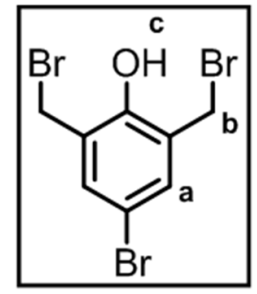

Bis((1-phenyl-1H-1,2,3-triazol-4-yl)methyl)amine (5): The compound was synthesized by a copper-catalyzed click-reaction. Tetrahydrofuran $(7 \mathrm{~mL})$ was added to a Schlenk tube and degassed. Copper(I) iodide ( 1 equiv., $1.15 \mathrm{mmol}, 219 \mathrm{mg}$ ) and DBU (5 equiv., $5.75 \mathrm{mmol}, 0.860 \mathrm{~mL}$ ) was added. The resulting green / blue color indicated an oxidation of at least some of the added copper. Sodium ascorbate (2 equiv., $2.30 \mathrm{mmol}, 456 \mathrm{mg}$ ) was added as a solid to the mixture. Deionized water was added until all sodium ascorbate was dissolved resulting in a color change back to yellow indicating reduction of copper(II) and the presence of copper(I). Afterwards,

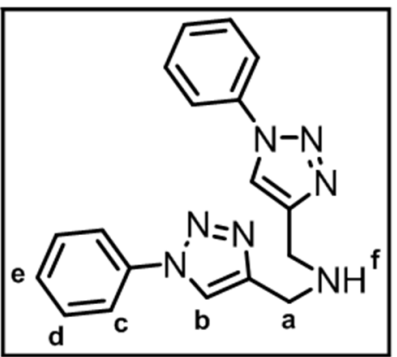
azidobenzene solution (3 equiv., $3.45 \mathrm{mmol}, 6.90 \mathrm{~mL}, 0.5 \mathrm{M}$ in 2-methyltetrahydrofurane) was added and the reaction mixture degassed again. Subsequent addition of dipropargylamine (1 equiv., $1.15 \mathrm{mmol}$, $107 \mathrm{mg}$ ) resulted in formation of a precipitate. The reaction mixture was heated at $70{ }^{\circ} \mathrm{C}$ for one day in the closed Schlenk tube under argon. The color of the precipitate changed from yellow to brown during this process and the reaction mixture was filtered after cooling. The filtrate was concentrated under reduced pressure and the residue dissolved in dichloromethane. The solution was washed two times with saturated sodium chloride and three times with a basic EDTA solution. Drying over magnesium sulfate, removal of the solvent under reduced pressure and purification using automated column chromatography (dichloromethane / methanol 0 - $5 \%$ gradient) resulted in the desired triazole product 5 as a colorless solid (57 \%, $0.65 \mathrm{mmol}, 216 \mathrm{mg}) .{ }^{1} \mathbf{H}$ NMR $\left(500 \mathrm{MHz}, 25^{\circ} \mathrm{C}, \mathrm{CDCl}_{3}\right): \delta=7.97\left(\mathrm{~s}, 2 \mathrm{H}, \mathrm{H}_{\mathrm{b}}\right), 7.72(\mathrm{~d}, J=$ $\left.7.6 \mathrm{~Hz}, 4 \mathrm{H}, \mathrm{H}_{\mathrm{c}}\right), 7.52\left(\mathrm{t}, J=7.9 \mathrm{~Hz}, 4 \mathrm{H}, \mathrm{H}_{\mathrm{d}}\right), 7.43\left(\mathrm{t}, J=7.4 \mathrm{~Hz}, 2 \mathrm{H}, \mathrm{H}_{\mathrm{e}}\right), 4.08\left(\mathrm{~s}, 4 \mathrm{H}, \mathrm{H}_{\mathrm{a}}\right), 2.00(\mathrm{~s}, 1 \mathrm{H}$, Hf) ppm. ${ }^{13} \mathbf{C}$ NMR $\left(126 \mathrm{MHz}, 25{ }^{\circ} \mathrm{C}, \mathrm{CDCl}_{3}\right): \delta=147.2,137.3,129.9,128.8,120.6,120.3,43.9 \mathrm{ppm}$. HRMS (positive ESI-FTMS): $\mathrm{m} / \mathrm{z}=332.1620\left(\left[\mathrm{M}+\mathrm{H}^{+}\right], \mathrm{C}_{18} \mathrm{H}_{18} \mathrm{~N}_{7}^{+}\right.$, calcd. 332.1618).

Dimethyl 2,2'-azanediyldiacetate (6): The compound was synthesized according to the literature procedure. ${ }^{4}$ The $\mathrm{HCl}$ salt was dissolved in water, neutralized with sodium carbonate solution and extracted with ethyl acetate three times. The combined organic layers were dried over magnesium sulfate and the solvent was removed under reduced pressure..$^{5-6}$ The product was obtained as a colorless oil

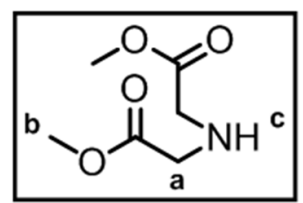
$(88 \%, 21.9 \mathrm{mmol}, 3.53 \mathrm{~g}) .{ }^{1} \mathbf{H}$ NMR $\left(600 \mathrm{MHz}, 25^{\circ} \mathrm{C}, \mathrm{CDCl}_{3}\right): \delta=3.73(\mathrm{~s}, 6 \mathrm{H}, \mathrm{Hb}), 3.47\left(\mathrm{~s}, 4 \mathrm{H}, \mathrm{H}_{\mathrm{a}}\right)$, $2.09\left(\mathrm{~s}, 1 \mathrm{H}, \mathrm{H}_{\mathrm{c}}\right) \mathrm{ppm}$. The NMR spectrum matches reported values and the compound was used without further purification. 
Diethyl 2,2'-azanediyldiacetate (7): The compound was synthesized according to the literature procedure with a small modification. ${ }^{7}$ The reaction mixture was concentrated in vacuo instead of being quenched. The colorless $\mathrm{HCl}$ salt was dissolved in water, neutralized with sodium carbonate solution and extracted with ethyl acetate three times. The combined organic layers were dried over

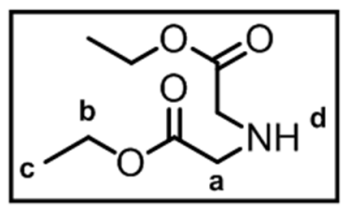
magnesium sulfate and the solvent removed under reduced pressure. ${ }^{8}$ The product is obtained as a yellow oil $(53 \%, 13.27 \mathrm{mmol}, 2.51 \mathrm{~g}) .{ }^{1} \mathbf{H}$ NMR $\left(600 \mathrm{MHz}, 25^{\circ} \mathrm{C}, \mathrm{CDCl}_{3}\right): \delta=4.19$ (q, $\left.J=7.1 \mathrm{~Hz}, 4 \mathrm{H}, \mathrm{Hb}\right)$, $3.47\left(\mathrm{~s}, 4 \mathrm{H}, \mathrm{H}_{\mathrm{a}}\right), 2.15\left(\mathrm{~s}, 1 \mathrm{H}, \mathrm{H}_{\mathrm{d}}\right), 1.28\left(\mathrm{t}, J=7.1 \mathrm{~Hz}, 6 \mathrm{H}, \mathrm{H}_{\mathrm{c}}\right) \mathrm{ppm}$. The NMR spectrum matches reported values and the compound was used without further purification.

Diisopropyl 2,2'-azanediyldiacetate (8): The compound was synthesized according to the synthetic procedure of compound $\mathbf{6}$ and isolated as a yellow oil $(53 \%, 26.3 \mathrm{mmol}, 5.71 \mathrm{~g}) .{ }^{1} \mathbf{H}$ NMR $\left(500 \mathrm{MHz}, 25{ }^{\circ} \mathrm{C}, \mathrm{CDCl}_{3}\right): \delta=5.06$ (hept, $J=6.3 \mathrm{~Hz}, 2 \mathrm{H}, \mathrm{Hb}), 3.41\left(\mathrm{~s}, 4 \mathrm{H}, \mathrm{H}_{\mathrm{a}}\right), 1.99(\mathrm{~s}, 1 \mathrm{H}, \mathrm{Hd}), 1.24(\mathrm{~d}, J=6.3 \mathrm{~Hz}, 12 \mathrm{H}$, $\left.\mathrm{H}_{\mathrm{c}}\right) \mathrm{ppm} .{ }^{13} \mathrm{C}$ NMR $\left(126 \mathrm{MHz}, 25{ }^{\circ} \mathrm{C}, \mathrm{CDCl}_{3}\right): \delta=171.4,68.5,50.6,22.0 \mathrm{ppm}$.

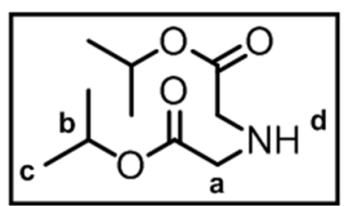
HRMS (positive APCI-FTMS): $\mathrm{m} / \mathrm{z}=218.1388\left(\left[\mathrm{M}+\mathrm{H}^{+}\right], \mathrm{C}_{10} \mathrm{H}_{20} \mathrm{NO}_{4}{ }^{+}\right.$, calcd. 218.1387).

Dibenzyl 2,2'-azanediyldiacetate (9): The compound was synthesized according to the literature procedure. ${ }^{5}$ Sodium carbonate solution was used for the neutralization instead of the described triethylamine to obviate washing with diluted $\mathrm{HCl}$. The chloroform layer was separated and the aqueous layer extracted two times with dichloromethane. The combined organic layers were dried over magnesium sulfate and concentrated in vacuo. The product was obtained as yellow oil $(95 \%, 21.5 \mathrm{mmol}, 6.74 \mathrm{~g})$.

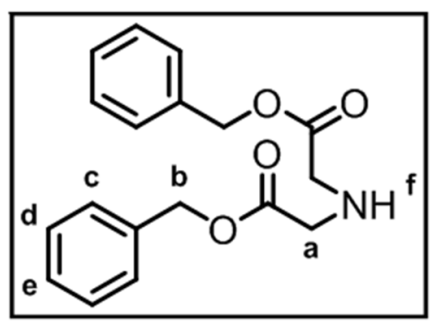
${ }^{1} \mathbf{H}$ NMR $\left(400 \mathrm{MHz}, 25^{\circ} \mathrm{C}, \mathrm{CDCl}_{3}\right): \delta=7.40-7.30\left(\mathrm{~m}, 10 \mathrm{H}, \mathrm{H}_{\mathrm{c}}, \mathrm{H}_{\mathrm{d}}\right.$ and $\left.\mathrm{H}_{\mathrm{e}}\right), 5.15\left(\mathrm{~s}, 4 \mathrm{H}, \mathrm{H}_{\mathrm{b}}\right), 3.50\left(\mathrm{~s}, 4 \mathrm{H}, \mathrm{H}_{\mathrm{a}}\right), 2.01\left(\mathrm{~s}, 1 \mathrm{H}, \mathrm{H}_{\mathrm{f}}\right) \mathrm{ppm}$. The NMR spectrum matches reported values and the compound was used without further purification.

General preparation of ligands: The ligand precursor 4-bromo-2,6-bis(bromomethyl)phenol (4) ( 1 equiv.) was added to a reaction tube and dissolved in chloroform $(0.1 \mathrm{M})$. The corresponding amine (2.2 equiv.) was added to the dissolved precursor followed by the base and the reaction mixture heated

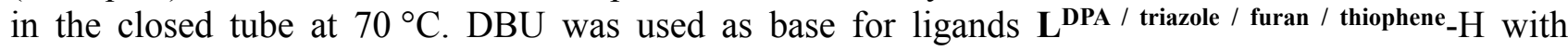
heteroaromatic binding pockets with a reaction time of three days. Triethylamine and a reaction time of two days were chosen for ester-containing ligands. The solvent was removed under reduced pressure and the ligands purified by automated column chromatography (Biotage Isolera One; self-packed recycled columns filled with ZEOprep 60 ECO / 40-63 $\mu \mathrm{m}$ Silicagel). 
2,6-Bis((bis(pyridin-2-ylmethyl)amino)methyl)-4-bromophenol (L $\left.{ }^{\text {DPA }}-\mathbf{H}\right)$ : The compound was synthesized according to the general procedure and obtained as a brown oil $(57 \%, 0.57 \mathrm{mmol}, 339 \mathrm{mg})$ after purification (dichloromethane / methanol $5-10 \%$ gradient). ${ }^{1} \mathbf{H}$ NMR $\left(500 \mathrm{MHz}, 25^{\circ} \mathrm{C}, \mathrm{CD}_{2} \mathrm{Cl}_{2}\right): \delta=8.51(\mathrm{dd}, J=4.8 \mathrm{~Hz}, 4 \mathrm{H}$, $\left.\mathrm{H}_{\mathrm{g}}\right), 7.62\left(\mathrm{td}, J=7.7,1.8 \mathrm{~Hz}, 4 \mathrm{H}, \mathrm{H}_{\mathrm{e}}\right), 7.44\left(\mathrm{~d}, J=7.8 \mathrm{~Hz}, 4 \mathrm{H}, \mathrm{H}_{\mathrm{d}}\right)$, $7.33\left(\mathrm{~s}, 2 \mathrm{H}, \mathrm{H}_{\mathrm{a}}\right), 7.14\left(\mathrm{dd}, J=6.5,5.0 \mathrm{~Hz}, 4 \mathrm{H}, \mathrm{H}_{\mathrm{f}}\right), 3.84\left(\mathrm{~s}, 8 \mathrm{H}, \mathrm{H}_{\mathrm{c}}\right)$, $3.76\left(\mathrm{~s}, 4 \mathrm{H}, \mathrm{H}_{\mathrm{b}}\right)$ ppm. The NMR spectrum matches reported values. ${ }^{9}$

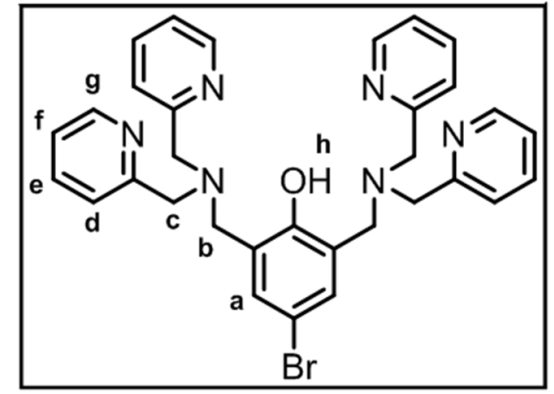

\section{2,6-Bis((bis((1-phenyl-1H-1,2,3-triazol-4-yl) methyl)amino)methyl)-4-bromophenol}

$\left(\mathbf{L}^{\text {triazole }}-\mathbf{H}\right)$ : The compound was synthesized according to the general procedure and obtained as a colorless solid $(56 \%, 0.113 \mathrm{mmol}, 97 \mathrm{mg})$ after purification (dichloromethane / methanol $0-5 \%$ gradient). ${ }^{1} \mathbf{H}$ NMR $\left(500 \mathrm{MHz}, 25^{\circ} \mathrm{C}, \mathrm{CDCl}_{3}\right): \delta=$ $11.06\left(\mathrm{~s}, 1 \mathrm{H}, \mathrm{H}_{\mathrm{h}}\right), 8.20\left(\mathrm{~s}, 4 \mathrm{H}, \mathrm{H}_{\mathrm{d}}\right), 7.77-7.72(\mathrm{~m}$, $8 \mathrm{H}, \mathrm{He}), 7.49(\mathrm{t}, J=7.8 \mathrm{~Hz}, 8 \mathrm{H}, \mathrm{Hf}), 7.41(\mathrm{t}, J=$ $\left.7.4 \mathrm{~Hz}, 4 \mathrm{H}, \mathrm{H}_{\mathrm{g}}\right), 7.34\left(\mathrm{~s}, 2 \mathrm{H}, \mathrm{H}_{\mathrm{a}}\right), 3.97\left(\mathrm{~s}, 8 \mathrm{H}, \mathrm{H}_{\mathrm{c}}\right)$, $3.91(\mathrm{~s}, 4 \mathrm{H}, \mathrm{Hb}) \mathrm{ppm} .{ }^{13} \mathbf{C} \mathbf{~ N M R}\left(126 \mathrm{MHz}, 25^{\circ} \mathrm{C}\right.$,

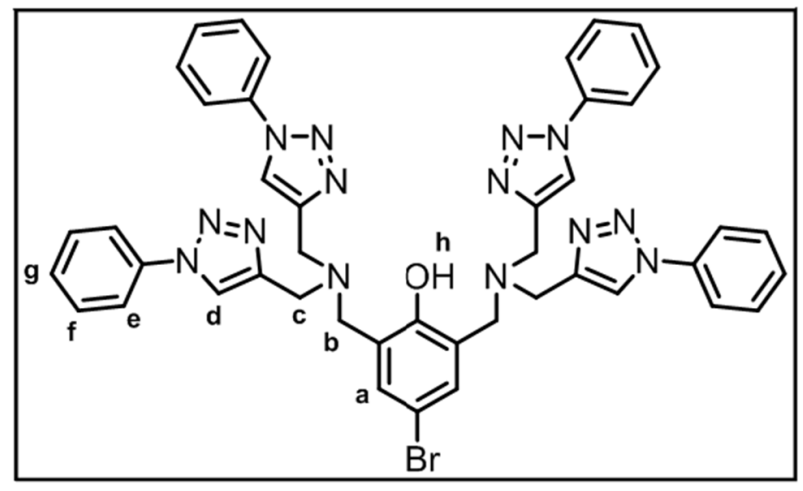
$\left.\mathrm{CDCl}_{3}\right): \delta=155.5,144.4,137.2,131.8,129.9,128.8,125.8,121.9,120.6,111.2,54.2,47.4$ ppm. HRMS (positive APCI-FTMS): $\mathrm{m} / \mathrm{z}=859.2695\left(\left[\mathrm{M}\left({ }^{79} \mathrm{Br}\right)+\mathrm{H}^{+}\right], \mathrm{C}_{44} \mathrm{H}_{40} \mathrm{BrN}_{14} \mathrm{O}^{+}\right.$, calcd. 859.2687), 861.2674 $\left(\left[\mathrm{M}\left({ }^{81} \mathrm{Br}\right)+\mathrm{H}^{+}\right], \mathrm{C}_{44} \mathrm{H}_{40} \mathrm{BrN}_{14} \mathrm{O}^{+}\right.$, calcd. 861.2677).

\section{2,6-Bis((bis(furan-2-ylmethyl)amino)methyl)-4-bromophenol} ( $\left.\mathbf{L}^{\text {furane}}-\mathbf{H}\right)$ : The compound was synthesized according to the general procedure and obtained as a colorless oil $(80 \%, 0.80 \mathrm{mmol}, 440 \mathrm{mg})$ after purification (hexanes / ethyl acetate $0-10 \%$ gradient). ${ }^{1} \mathbf{H}$ NMR $\left(500 \mathrm{MHz}, 25{ }^{\circ} \mathrm{C}, \mathrm{CDCl}_{3}\right): \delta=7.43-7.38\left(\mathrm{~m}, 4 \mathrm{H}, \mathrm{H}_{\mathrm{f}}\right), 7.28$ $\left(\mathrm{s}, 2 \mathrm{H}, \mathrm{H}_{\mathrm{a}}\right), 6.35-6.32\left(\mathrm{~m}, 4 \mathrm{H}, \mathrm{H}_{\mathrm{e}}\right), 6.27\left(\mathrm{~d}, J=2.8 \mathrm{~Hz}, 4 \mathrm{H}, \mathrm{H}_{\mathrm{d}}\right), 3.71-$ $3.70\left(2 \mathrm{x} \mathrm{s}\right.$, overlapping, $12 \mathrm{H}, \mathrm{H}_{\mathrm{b}}$ and $\left.\mathrm{H}_{\mathrm{c}}\right)$ ppm. ${ }^{13} \mathrm{C}$ NMR $(126 \mathrm{MHz}$, $\left.25^{\circ} \mathrm{C}, \mathrm{CDCl}_{3}\right): \delta=155.4,151.4,142.5,131.1,125.8,111.1,110.3$, 109.6, 53.2, 49.2 ppm. HRMS (positive ESI-FTMS): $\mathrm{m} / \mathrm{z}=$

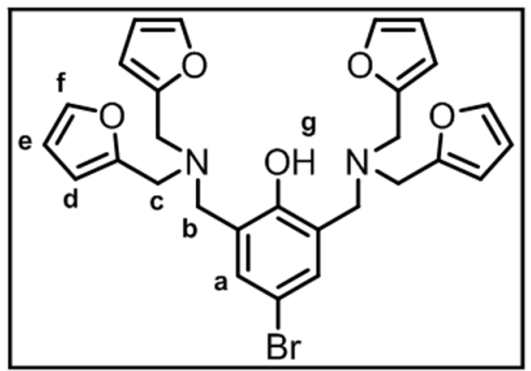
$573.0994\left(\left[\mathrm{M}\left({ }^{79} \mathrm{Br}\right)+\mathrm{Na}^{+}\right], \quad \mathrm{C}_{28} \mathrm{H}_{27} \mathrm{BrN}_{2} \mathrm{O}_{5} \mathrm{Na}^{+}, \quad\right.$ calcd. 573.0996$), \quad 575.0973 \quad\left(\left[\mathrm{M}\left({ }^{81} \mathrm{Br}\right)+\mathrm{Na}^{+}\right]\right.$, $\mathrm{C}_{28} \mathrm{H}_{27} \mathrm{BrN}_{2} \mathrm{O}_{5} \mathrm{Na}^{+}$, calcd. 575.0980). 
2,6-Bis((bis(thiophen-2-ylmethyl)amino)methyl)-4-bromophenol ( $\left.\mathbf{L}^{\text {thiophen }}-\mathbf{H}\right)$ : The compound was synthesized according to the general procedure and obtained as a colorless sticky oil $(60 \%$, $0.298 \mathrm{mmol}, 184 \mathrm{mg}$ ) after purification (hexanes / ethyl acetate $5 \%$ ). ${ }^{1} \mathrm{H}$ NMR $\left(500 \mathrm{MHz}, 25^{\circ} \mathrm{C}, \mathrm{CD}_{2} \mathrm{Cl}_{2}\right): \delta=10.42\left(\mathrm{~s}, 1 \mathrm{H}, \mathrm{H}_{\mathrm{g}}\right), 7.38(\mathrm{~s}$, $\left.2 \mathrm{H}, \mathrm{H}_{\mathrm{a}}\right), 7.29\left(\mathrm{dd}, J=4.1,2.2 \mathrm{~Hz}, 4 \mathrm{H}, \mathrm{H}_{\mathrm{f}}\right), 6.99-6.96\left(\mathrm{~m}, 8 \mathrm{H}, \mathrm{H}_{\mathrm{d}}\right.$ and $\left.\mathrm{He}_{\mathrm{e}}\right), 3.86\left(\mathrm{~s}, 8 \mathrm{H}, \mathrm{H}_{\mathrm{c}}\right), 3.73(\mathrm{~s}, 4 \mathrm{H}, \mathrm{Hb}) \mathrm{ppm} .{ }^{13} \mathrm{C}$ NMR $(126 \mathrm{MHz}$, $\left.25^{\circ} \mathrm{C}, \mathrm{CD}_{2} \mathrm{Cl}_{2}\right): \delta=155.6,141.4,131.3,127.4,127.2,126.3,125.9$, 111.7, 53.3, 52.0 ppm. HRMS (positive APCI-FTMS): $\mathrm{m} / \mathrm{z}=$

$615.0263\left(\left[\mathrm{M}\left({ }^{79} \mathrm{Br}\right)+\mathrm{H}^{+}\right], \quad \mathrm{C}_{28} \mathrm{H}_{28} \mathrm{BrN}_{2} \mathrm{OS}_{4}{ }^{+}, \quad\right.$ calcd. 615.0262$), \quad 617.0239 \quad\left(\left[\mathrm{M}\left({ }^{81} \mathrm{Br}\right)+\mathrm{H}^{+}\right]\right.$, $\mathrm{C}_{28} \mathrm{H}_{28} \mathrm{BrN}_{2} \mathrm{OS}_{4}{ }^{+}$, calcd. 617.0243).

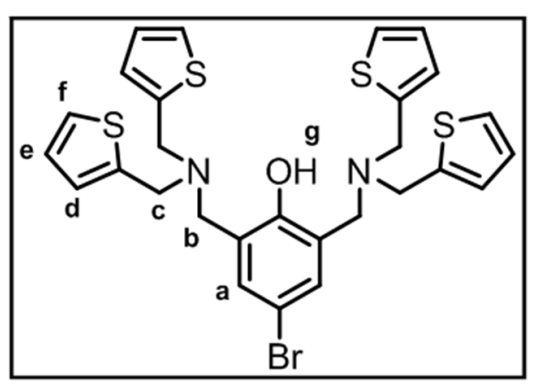

Tetramethyl 2,2',2",2"'-(((5-bromo-2-hydroxy-1,3-phenylene) bis (methylene))bis(azanetriyl))tetraacetate $\left(\mathrm{L}^{\mathrm{Me}}-\mathrm{H}\right):{ }^{10}$ The compound was synthesized according to the general procedure and obtained as a colorless oil $(80 \%, 0.752 \mathrm{mmol}, 391 \mathrm{mg})$ after purification (hexanes / ethyl acetate $50 \%)$. ${ }^{1} \mathbf{H}$ NMR $(500 \mathrm{MHz}$, $\left.25{ }^{\circ} \mathrm{C}, \mathrm{CD}_{2} \mathrm{Cl}_{2}\right): \delta=7.26\left(\mathrm{~s}, 2 \mathrm{H}, \mathrm{H}_{\mathrm{a}}\right), 3.89(\mathrm{~s}, 4 \mathrm{H}, \mathrm{Hb}), 3.70(\mathrm{~s}, 12 \mathrm{H}$, $\left.\mathrm{H}_{\mathrm{d}}\right), 3.53\left(\mathrm{~s}, 8 \mathrm{H}, \mathrm{H}_{\mathrm{c}}\right) \mathrm{ppm} .{ }^{13} \mathbf{C} \mathbf{N M R}\left(126 \mathrm{MHz}, 25^{\circ} \mathrm{C}, \mathrm{CD}_{2} \mathrm{Cl}_{2}\right): \delta=$ $171.9,155.5,132.5,126.1,111.2,54.6,54.2,52.2$ ppm. HRMS

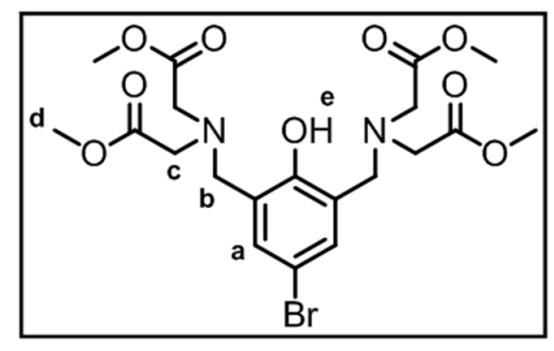
(positive ESI-FTMS): $\mathrm{m} / \mathrm{z}=541.0793\left(\left[\mathrm{M}\left({ }^{79} \mathrm{Br}\right)+\mathrm{Na}^{+}\right], \mathrm{C}_{20} \mathrm{H}_{27} \mathrm{BrN}_{2} \mathrm{O}_{9} \mathrm{Na}^{+}\right.$, calcd. 541.0792), 543.0772 $\left(\left[\mathrm{M}\left({ }^{81} \mathrm{Br}\right)+\mathrm{Na}^{+}\right], \mathrm{C}_{20} \mathrm{H}_{27} \mathrm{BrN}_{2} \mathrm{O}_{9} \mathrm{Na}^{+}\right.$, calcd. 543.0775).

Tetraethyl 2,2',2",2"'-(((5-bromo-2-hydroxy-1,3-phenylene) bis(methylene))bis(azanetriyl))tetraacetate $\left(\mathrm{L}^{\mathrm{Et}}-\mathrm{H}\right)$ : The compound was synthesized according to the general procedure and obtained as a colorless oil $(59 \%, 0.426 \mathrm{mmol}$, $245 \mathrm{mg}$ ) after purification (hexanes / ethyl acetate $30 \%$ ). ${ }^{1}$ H NMR (500 MHz, $\left.25{ }^{\circ} \mathrm{C}, \mathrm{CD}_{2} \mathrm{Cl}_{2}\right): \delta=7.27$ (s, 2H, $\left.\mathrm{H}_{\mathrm{a}}\right), 4.16$ (q, $\left.J=7.1 \mathrm{~Hz}, 8 \mathrm{H}, \mathrm{H}_{\mathrm{d}}\right), 3.89(\mathrm{~s}, 4 \mathrm{H}, \mathrm{Hb}), 3.51\left(\mathrm{~s}, 8 \mathrm{H}, \mathrm{H}_{\mathrm{c}}\right), 1.26$ $\left(\mathrm{t}, J=7.1 \mathrm{~Hz}, 12 \mathrm{H}, \mathrm{H}_{\mathrm{e}}\right) \mathrm{ppm} .{ }^{13} \mathbf{C}$ NMR $\left(126 \mathrm{MHz}, 25^{\circ} \mathrm{C}\right.$,

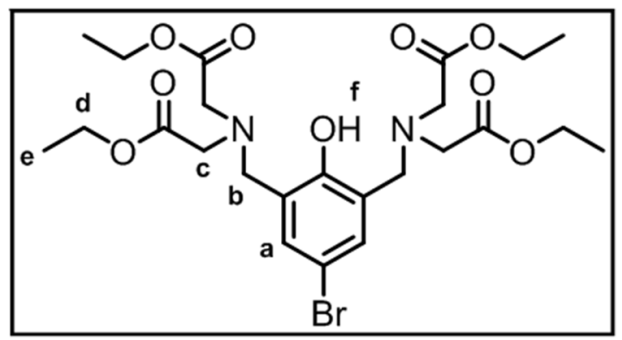
$\mathrm{CD}_{2} \mathrm{Cl}_{2}$ ): $\delta=171.5,155.5,132.4,126.2,111.2,61.3,54.9,54.1,14.6$ ppm. HRMS (positive ESI-FTMS): $\mathrm{m} / \mathrm{z}=597.1420\left(\left[\mathrm{M}\left({ }^{79} \mathrm{Br}\right)+\mathrm{Na}^{+}\right], \mathrm{C}_{24} \mathrm{H}_{35} \mathrm{BrN}_{2} \mathrm{O}_{9} \mathrm{Na}^{+}\right.$, calcd. 597.1418), $599.1398\left(\left[\mathrm{M}\left({ }^{81} \mathrm{Br}\right)+\mathrm{Na}^{+}\right]\right.$, $\mathrm{C}_{24} \mathrm{H}_{35} \mathrm{BrN}_{2} \mathrm{O}_{9} \mathrm{Na}^{+}$, calcd. 599.1402). 

general procedure and obtained as a yellowish oil $(71 \%$, $0.705 \mathrm{mmol}, 445 \mathrm{mg}$ ) after purification (hexanes / ethyl acetate $0-15 \%$ gradient). ${ }^{1} \mathbf{H}$ NMR $\left(500 \mathrm{MHz}, 25{ }^{\circ} \mathrm{C}, \mathrm{CD}_{2} \mathrm{Cl}_{2}\right): \delta=$ $7.27\left(\mathrm{~s}, 2 \mathrm{H}, \mathrm{H}_{\mathrm{a}}\right), 5.04$ (hept, $\left.J=6.3 \mathrm{~Hz}, 4 \mathrm{H}, \mathrm{Hd}\right), 3.88(\mathrm{~s}, 4 \mathrm{H}$, $\left.\mathrm{H}_{\mathrm{b}}\right), 3.47\left(\mathrm{~s}, 8 \mathrm{H}, \mathrm{H}_{\mathrm{c}}\right), 1.24\left(\mathrm{~d}, J=6.3 \mathrm{~Hz}, 24 \mathrm{H}, \mathrm{H}_{\mathrm{e}}\right)$ ppm.

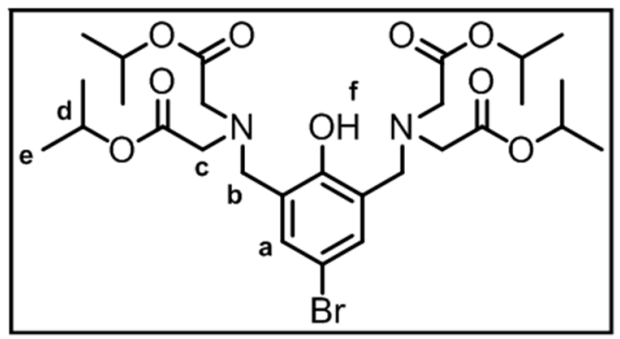

${ }^{13} \mathbf{C}$ NMR $\left(126 \mathrm{MHz}, 25{ }^{\circ} \mathrm{C}, \mathrm{CD}_{2} \mathrm{Cl}_{2}\right): \delta=171.0,155.5,132.3,126.3,111.2,68.9,55.2,22.2 \mathrm{ppm}$. HRMS (positive ESI-FTMS): $\mathrm{m} / \mathrm{z}=653.2046\left(\left[\mathrm{M}\left({ }^{79} \mathrm{Br}\right)+\mathrm{Na}^{+}\right], \mathrm{C}_{28} \mathrm{H}_{43} \mathrm{BrN}_{2} \mathrm{O}_{9} \mathrm{Na}^{+}\right.$, calcd. 653.2044), 655.2027 $\left(\left[\mathrm{M}\left({ }^{81} \mathrm{Br}\right)+\mathrm{Na}^{+}\right], \mathrm{C}_{28} \mathrm{H}_{43} \mathrm{BrN}_{2} \mathrm{O}_{9} \mathrm{Na}^{+}\right.$, calcd. 655.2029).

Tetrabenzyl 2,2',2",2'"'-(((5-bromo-2-hydroxy-1,3 -phenylene)bis(methylene))bis(azanetriyl))tetraacetate $\left(\mathbf{L}^{\mathbf{B z}}-\mathbf{H}\right)$ : The compound was synthesized according to the general procedure and obtained as a yellowish oil (79\%, $0.794 \mathrm{mmol}, 654 \mathrm{mg})$ after purification (hexanes / ethyl acetate 0 - $40 \%$ gradient). ${ }^{1} \mathbf{H}$ NMR $\left(500 \mathrm{MHz}, 25^{\circ} \mathrm{C}, \mathrm{CD}_{2} \mathrm{Cl}_{2}\right): \delta=$ $9.57\left(\mathrm{~s}, 1 \mathrm{H}, \mathrm{H}_{\mathrm{h}}\right), 7.39-7.30\left(\mathrm{~m}, 20 \mathrm{H}, \mathrm{H}_{\mathrm{e}}, \mathrm{H}_{\mathrm{f}}\right.$ and $\left.\mathrm{H}_{\mathrm{g}}\right)$, $7.24\left(\mathrm{~s}, 2 \mathrm{H}, \mathrm{H}_{\mathrm{a}}\right), 5.14\left(\mathrm{~s}, 8 \mathrm{H}, \mathrm{H}_{\mathrm{d}}\right), 3.91(\mathrm{~s}, 4 \mathrm{H}, \mathrm{Hb})$,<smiles>O=C(CN(CC(=O)OCc1ccccc1)Cc1cc(Br)cc(CN(CC(=O)OCc2ccccc2)CC(=O)OCc2ccccc2)c1O)OCc1ccccc1</smiles>
$3.58\left(\mathrm{~s}, 8 \mathrm{H}, \mathrm{H}_{\mathrm{c}}\right) \mathrm{ppm} .{ }^{13} \mathrm{C}$ NMR $\left(126 \mathrm{MHz}, 25{ }^{\circ} \mathrm{C}, \mathrm{CD}_{2} \mathrm{Cl}_{2}\right): \delta=171.4,155.5,136.4,132.5,129.1,128.8$, 128.8, 126.1, 111.3, 67.0, 54.9, 54.0 ppm. HRMS (positive APCI-FTMS): $\mathrm{m} / \mathrm{z}=823.2230$ $\left(\left[\mathrm{M}\left({ }^{79} \mathrm{Br}\right)+\mathrm{H}^{+}\right], \mathrm{C}_{44} \mathrm{H}_{44} \mathrm{BrN}_{2} \mathrm{O}_{9}{ }^{+}\right.$, calcd. 823.2225), $825.2215\left(\left[\mathrm{M}\left({ }^{81} \mathrm{Br}\right)+\mathrm{H}^{+}\right], \mathrm{C}_{44} \mathrm{H}_{44} \mathrm{BrN}_{2} \mathrm{O}_{9}{ }^{+}\right.$, calcd. $825.2214)$. 


\section{Magnesium Binding Studies}

\subsection{Magnesium binding with $\mathrm{L}^{\mathrm{DPA}}-\mathrm{H}$ :}
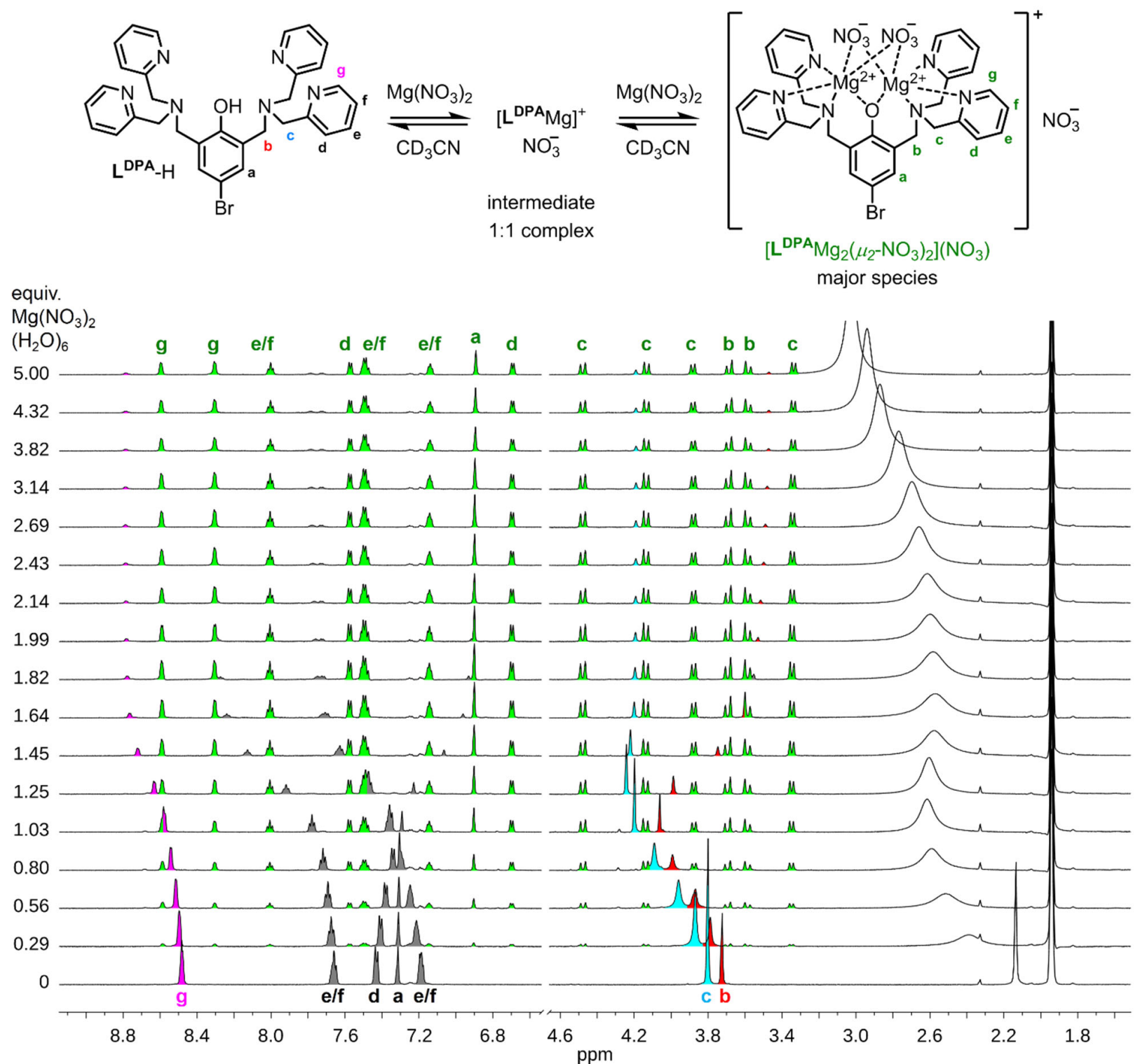

Figure S1: NMR titration (600 MHz) for the binding behavior of bisdipicolylamine ligand $\mathbf{L}^{\mathbf{D P A}}-\mathrm{H}$ upon addition of magnesium(II) nitrate hexahydrate in acetonitrile- $d_{3}$ at $25^{\circ} \mathrm{C}$. The ligand concentration is $5 \mathrm{mM}$ and the titration is performed with dilution correction. 


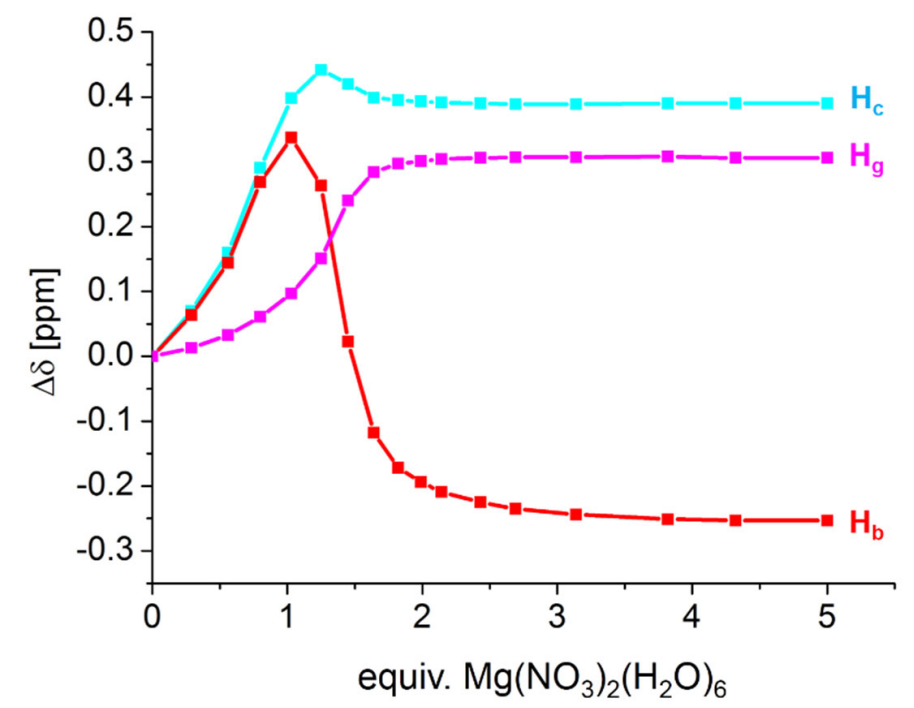

Figure S2: Titration data showing NMR shifts upon addition of magnesium(II) nitrate hexahydrate to bisdipicolylamine ligand $\mathbf{L}^{\text {DPA}}-\mathbf{H}$ for the titration in Figure $\mathrm{S} 1$.

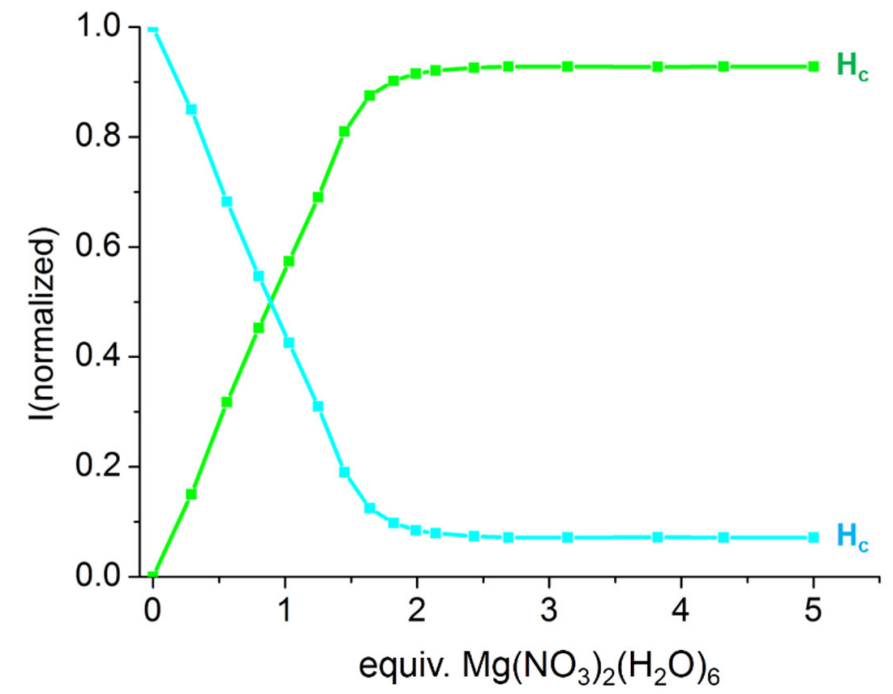

Figure S3: Normalized intensity changes observed upon addition of magnesium(II) nitrate hexahydrate to bisdipicolylamine ligand $\mathbf{L}^{\text {DPA }}-\mathrm{H}$ for the titration in Figure S1. 

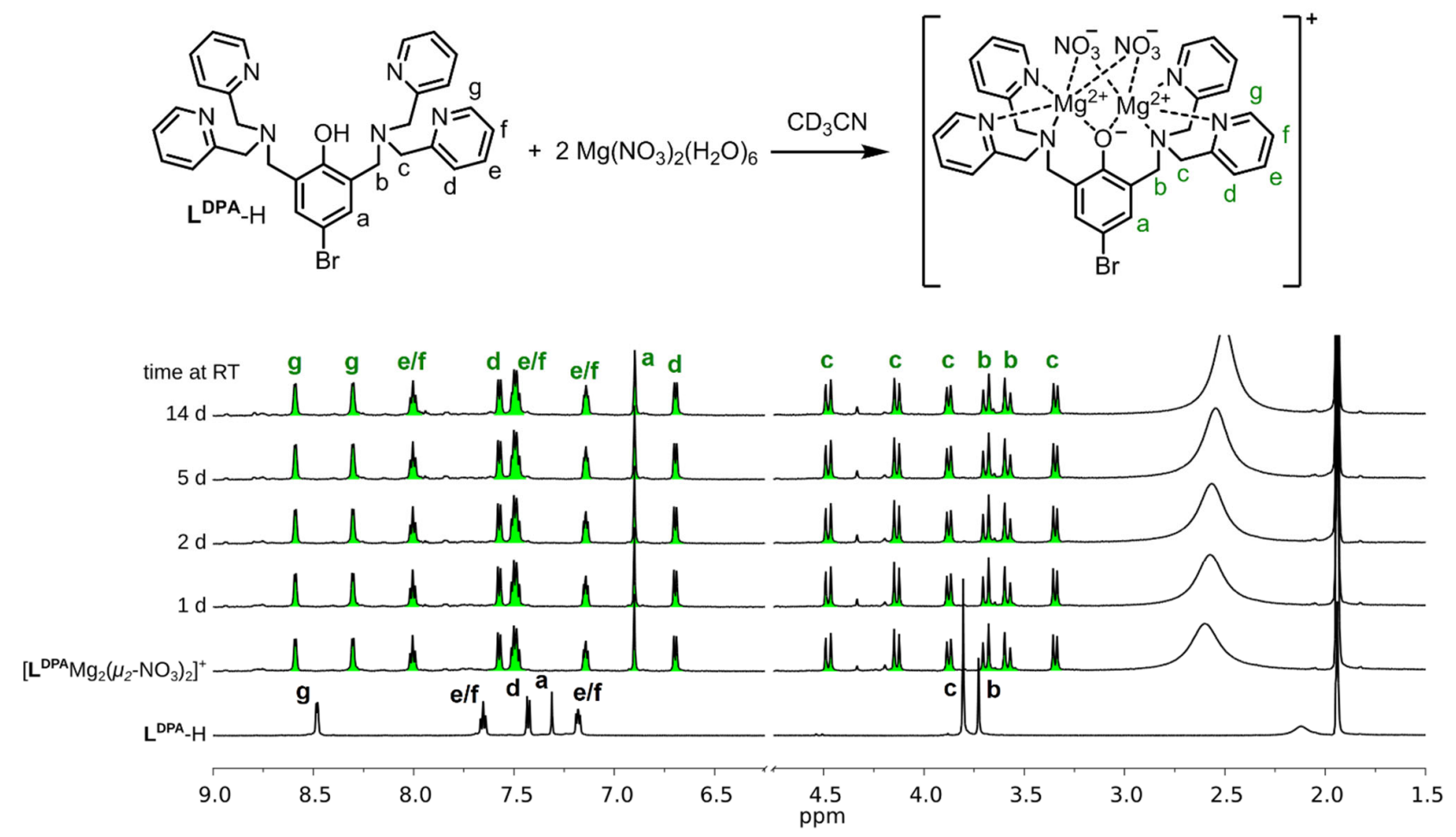

Figure S4: Proof of the complex stability $\left(5 \mathrm{mM}, 600 \mathrm{MHz}, \mathrm{CD}_{3} \mathrm{CN}, 25^{\circ} \mathrm{C}\right)$. The bimetallic magnesium complex was prepared in situ in a NMR tube and checked for decomposition over time. No decomposition was observed which shows that the complex is maintained in solution.

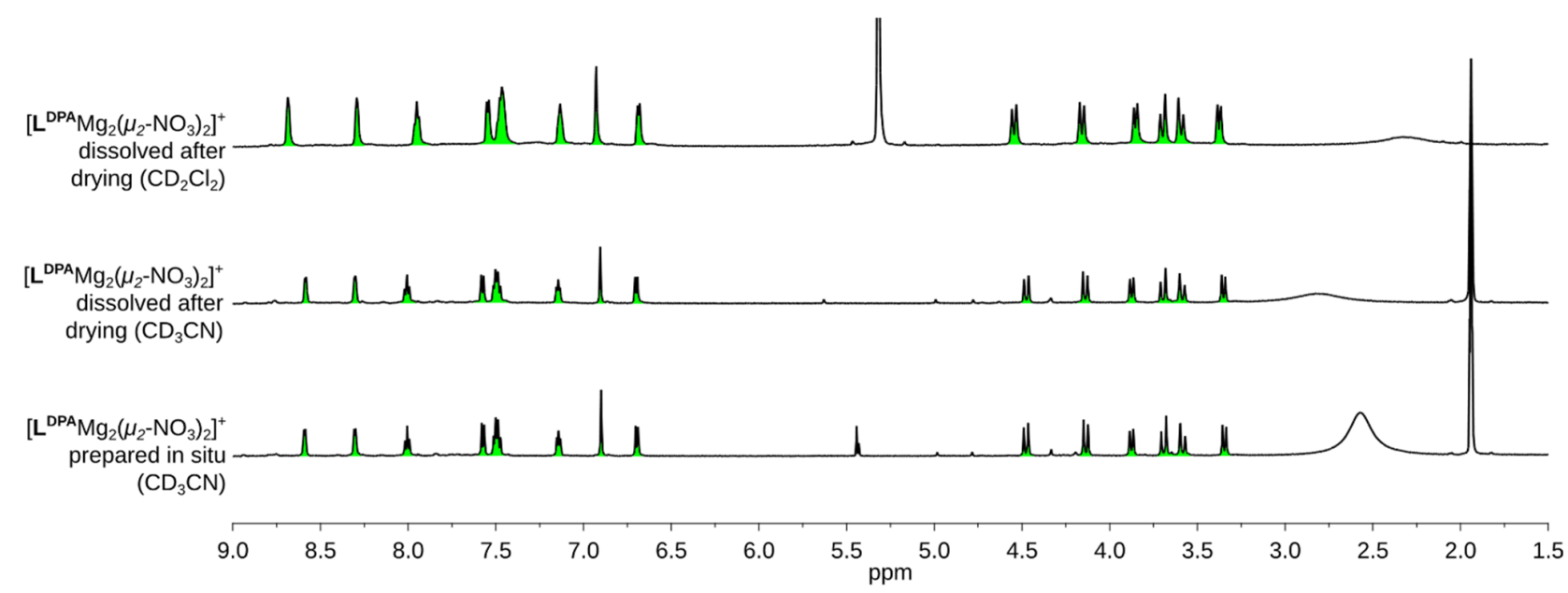

Figure S5: The bimetallic magnesium complex of $\mathbf{L}^{\mathbf{D P A}}$ was prepared in situ $\left(5 \mathrm{mM}, \mathrm{CD}_{3} \mathrm{CN}, 25^{\circ} \mathrm{C}\right)$ and the solvent was removed under reduced pressure. The dried complex (green solid) was redissolved in $\mathrm{CD}_{3} \mathrm{CN}$ and $\mathrm{CD}_{2} \mathrm{Cl}_{2}$ to show that isolation and further use is possible. 


\subsection{Magnesium binding with $\mathrm{L}^{\text {triazole }}-\mathrm{H}$ :}
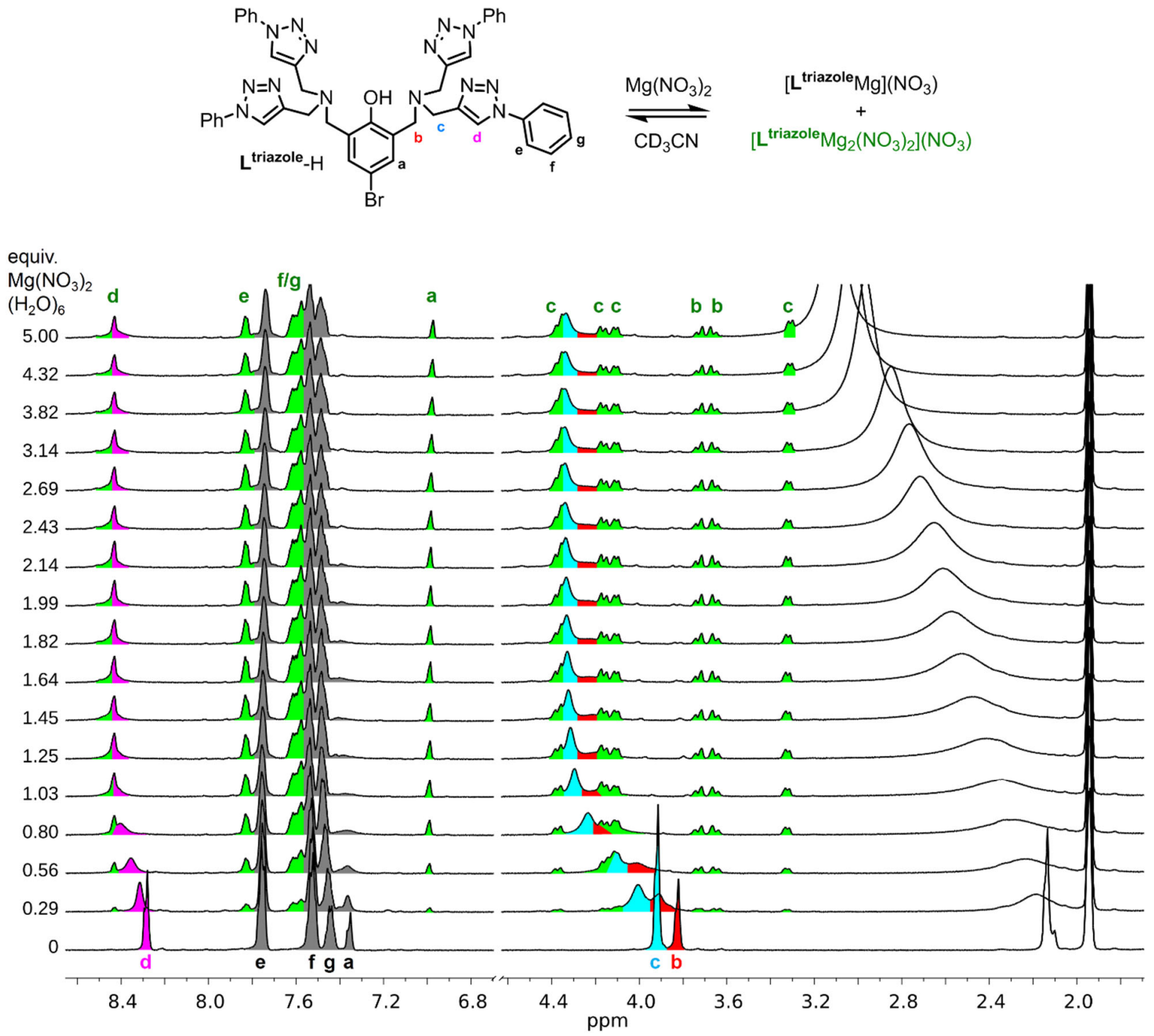

Figure S6: NMR titration $(600 \mathrm{MHz})$ for the binding behavior of the triazole ligand $\mathbf{L}^{\text {triazole }}-\mathrm{H}$ upon addition of magnesium(II) nitrate hexahydrate in acetonitrile- $d_{3}$ at $25{ }^{\circ} \mathrm{C}$. The ligand concentration is $5 \mathrm{mM}$ and the titration is performed with dilution correction. 


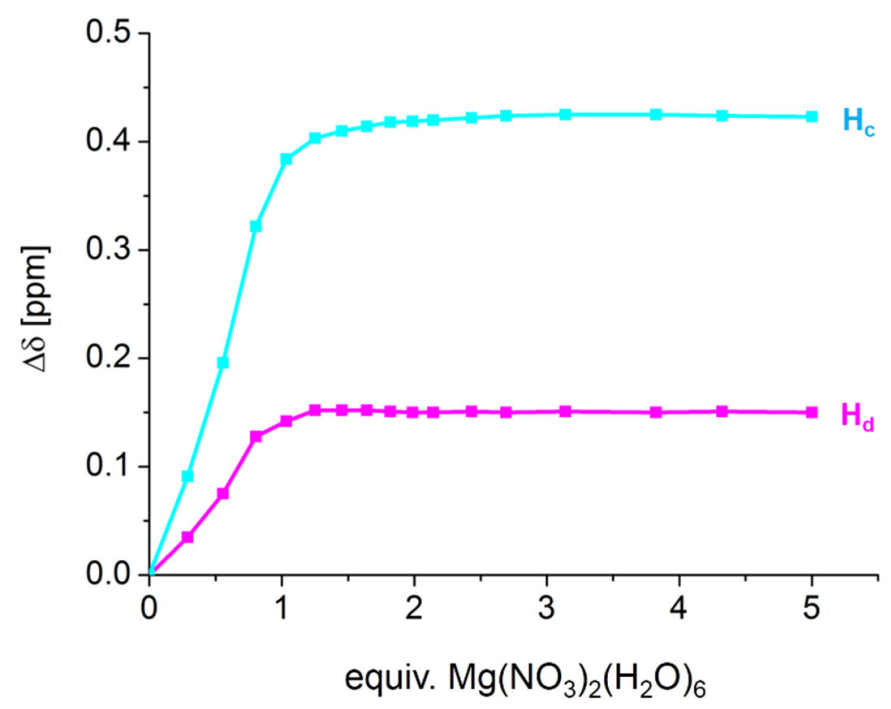

Figure S7: Titration data showing NMR shifts upon addition of magnesium(II) nitrate hexahydrate to triazole ligand $\mathbf{L}^{\text {triazole }}-\mathbf{H}$ for the titration in Figure $\mathbf{S} 6$.

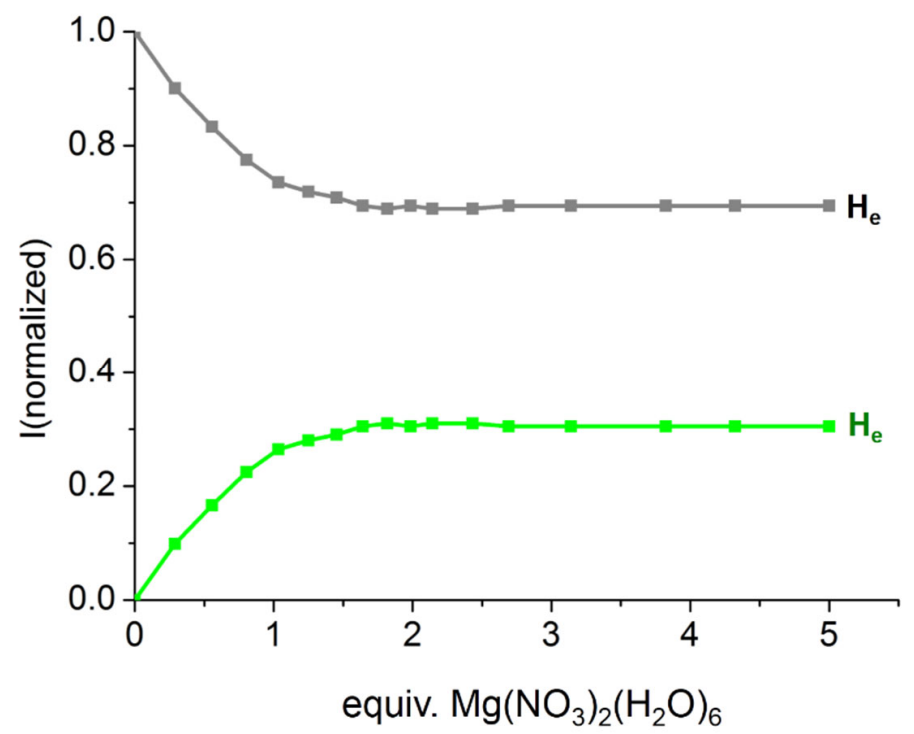

Figure S8: Normalized intensity changes observed upon addition of magnesium(II) nitrate hexahydrate to triazole ligand $\mathbf{L}^{\text {triazole }}-\mathrm{H}$ for the titration in Figure S6. 


\subsection{Magnesium binding with $\mathrm{L}^{\text {furan }}-\mathrm{H}$ :}
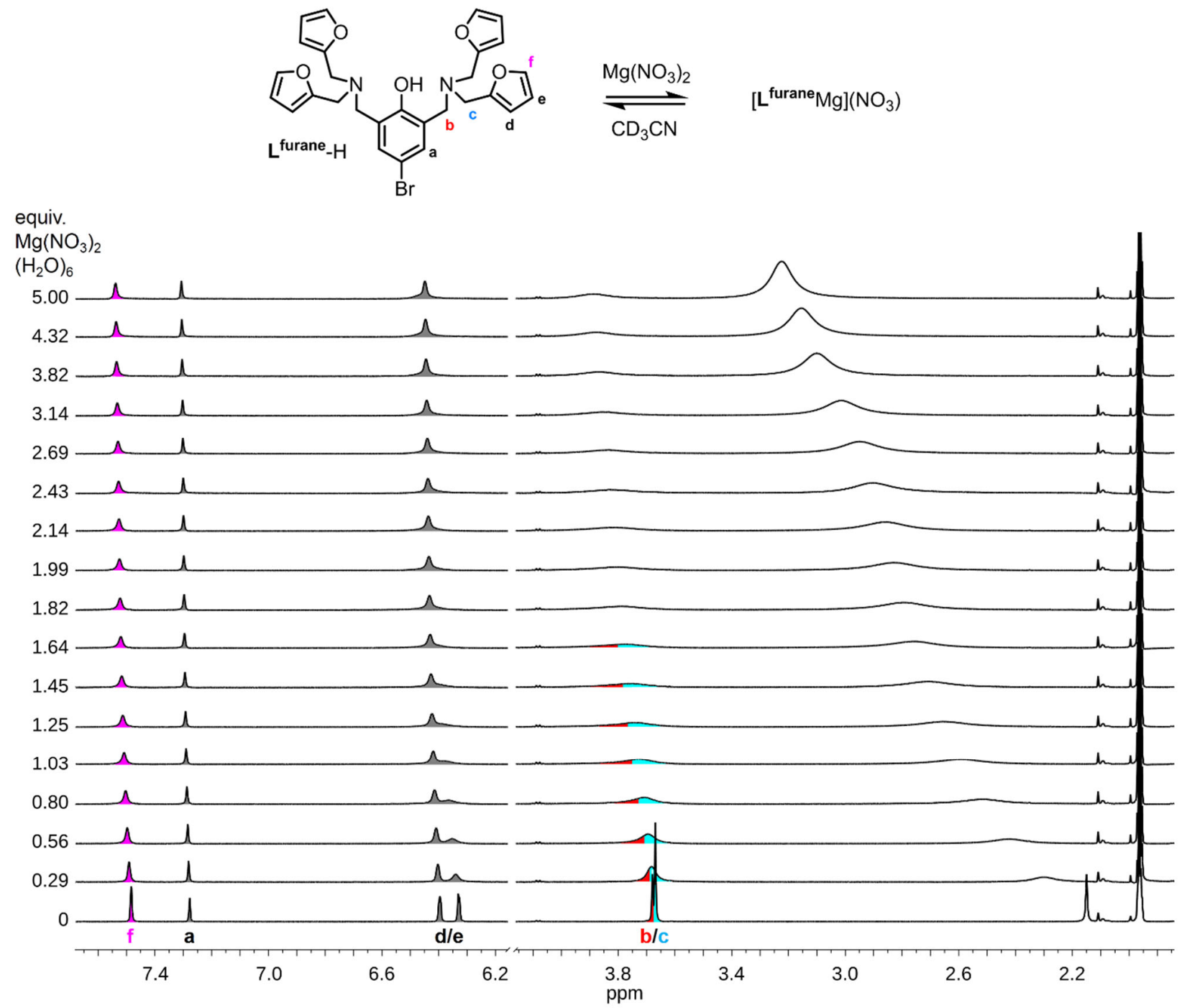

Figure S9: NMR titration $(600 \mathrm{MHz})$ for the binding behavior of the furan ligand $\mathbf{L}^{\text {furan }}$-H upon addition of magnesium(II) nitrate hexahydrate in acetonitrile- $d_{3}$ at $25^{\circ} \mathrm{C}$. The ligand concentration is $5 \mathrm{mM}$ and the titration is performed with dilution correction. 


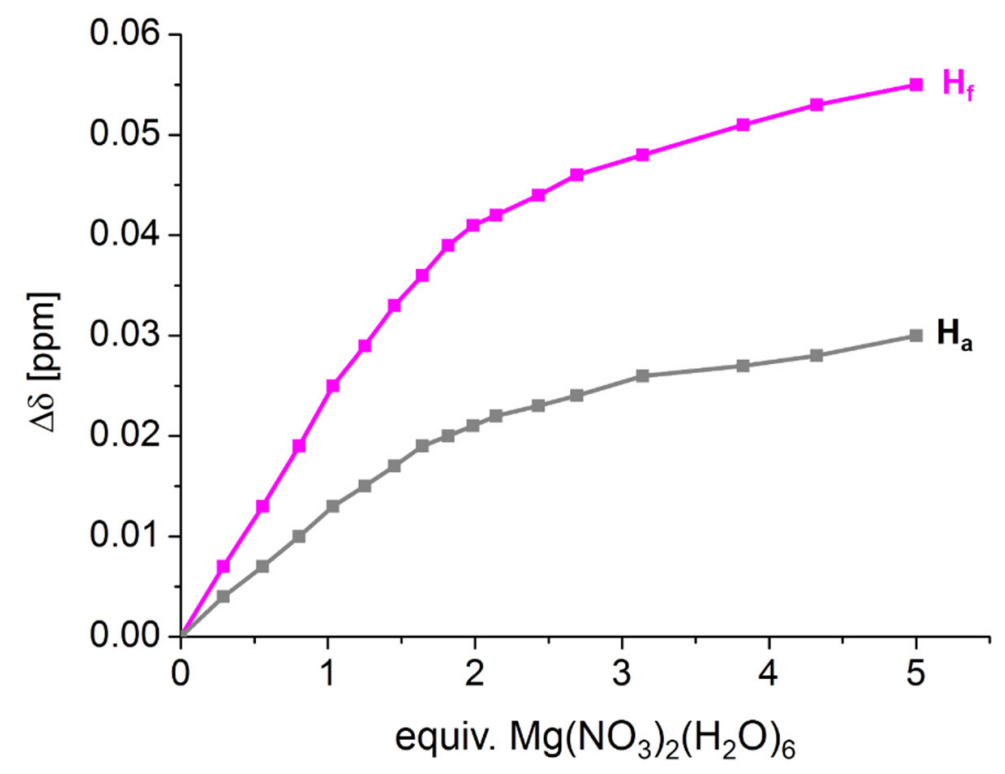

Figure S10: Titration data showing NMR shifts upon addition of magnesium(II) nitrate hexahydrate to furan ligand $\mathbf{L}^{\text {furan }}-\mathrm{H}$ for the titration in Figure S9. 
3.4 Magnesium binding with $L^{\text {thiophene-H: }}$

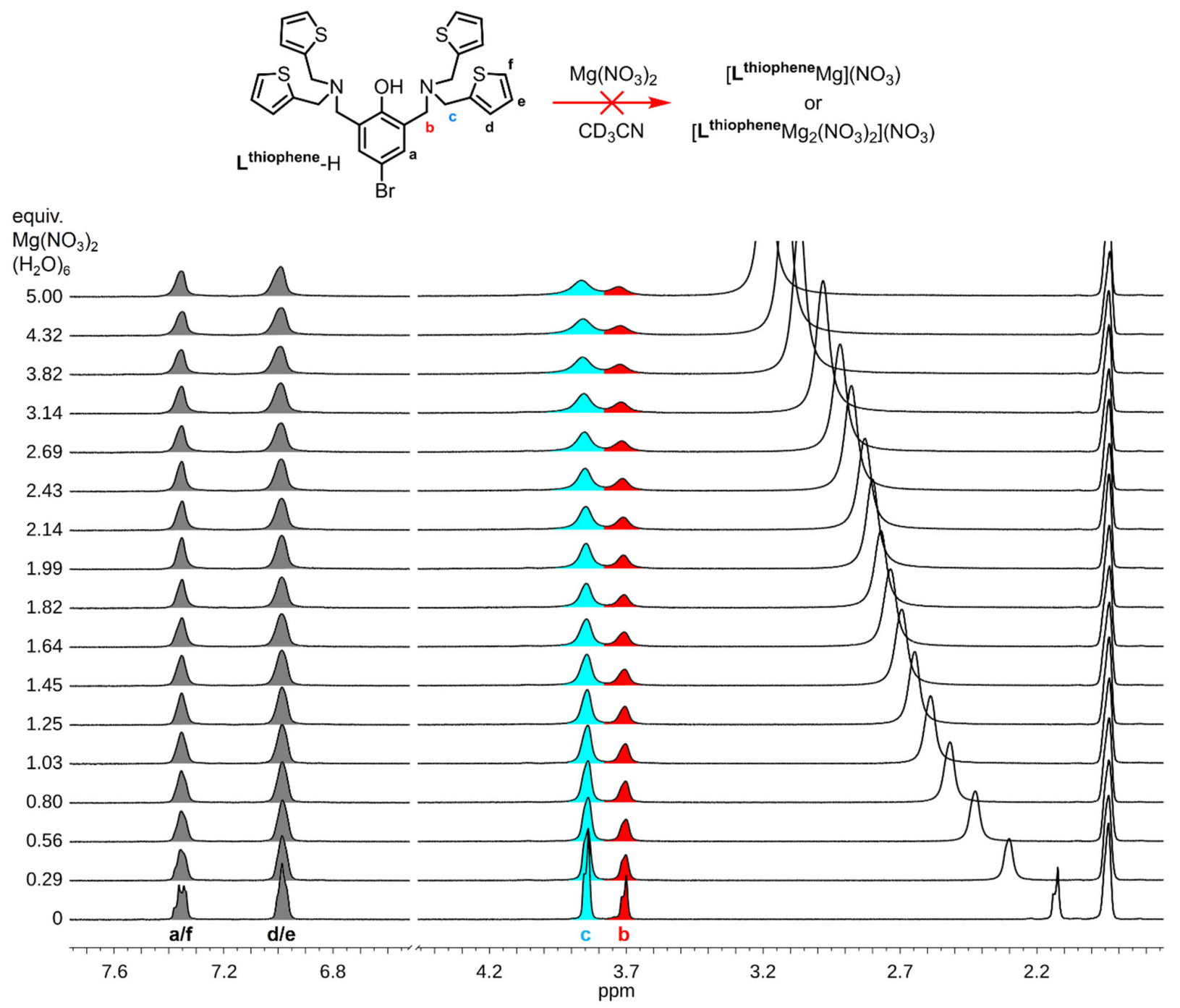

Figure S11: NMR titration (600 MHz) for the binding behavior of the thiophene ligand $\mathbf{L}^{\text {thiophene }}$-H upon addition of magnesium(II) nitrate hexahydrate in acetonitrile- $d_{3}$ at $25{ }^{\circ} \mathrm{C}$. The ligand concentration is $5 \mathrm{mM}$ and the titration is performed with dilution correction. 


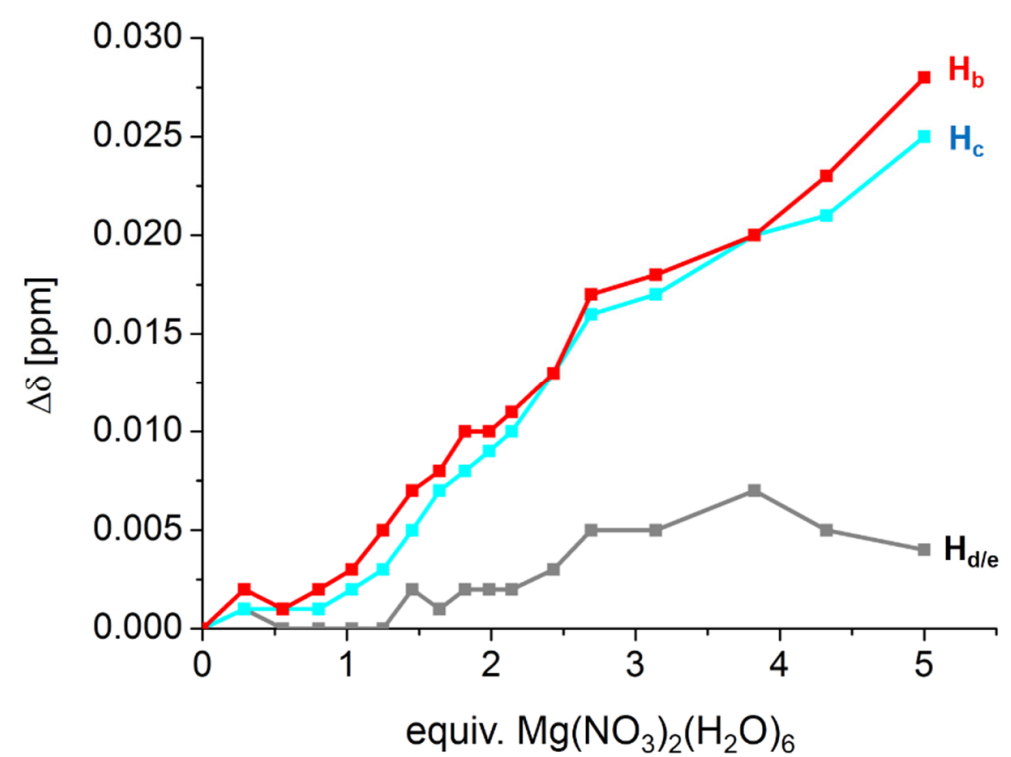

Figure S12: Titration data showing NMR shifts upon addition of magnesium(II) nitrate hexahydrate to thiophene ligand $\mathbf{L}^{\text {thiophene}}-\mathrm{H}$ for the titration in Figure S11. 


\subsection{Magnesium binding with $\mathrm{L}^{\mathrm{Me}}-\mathrm{H}$ :}
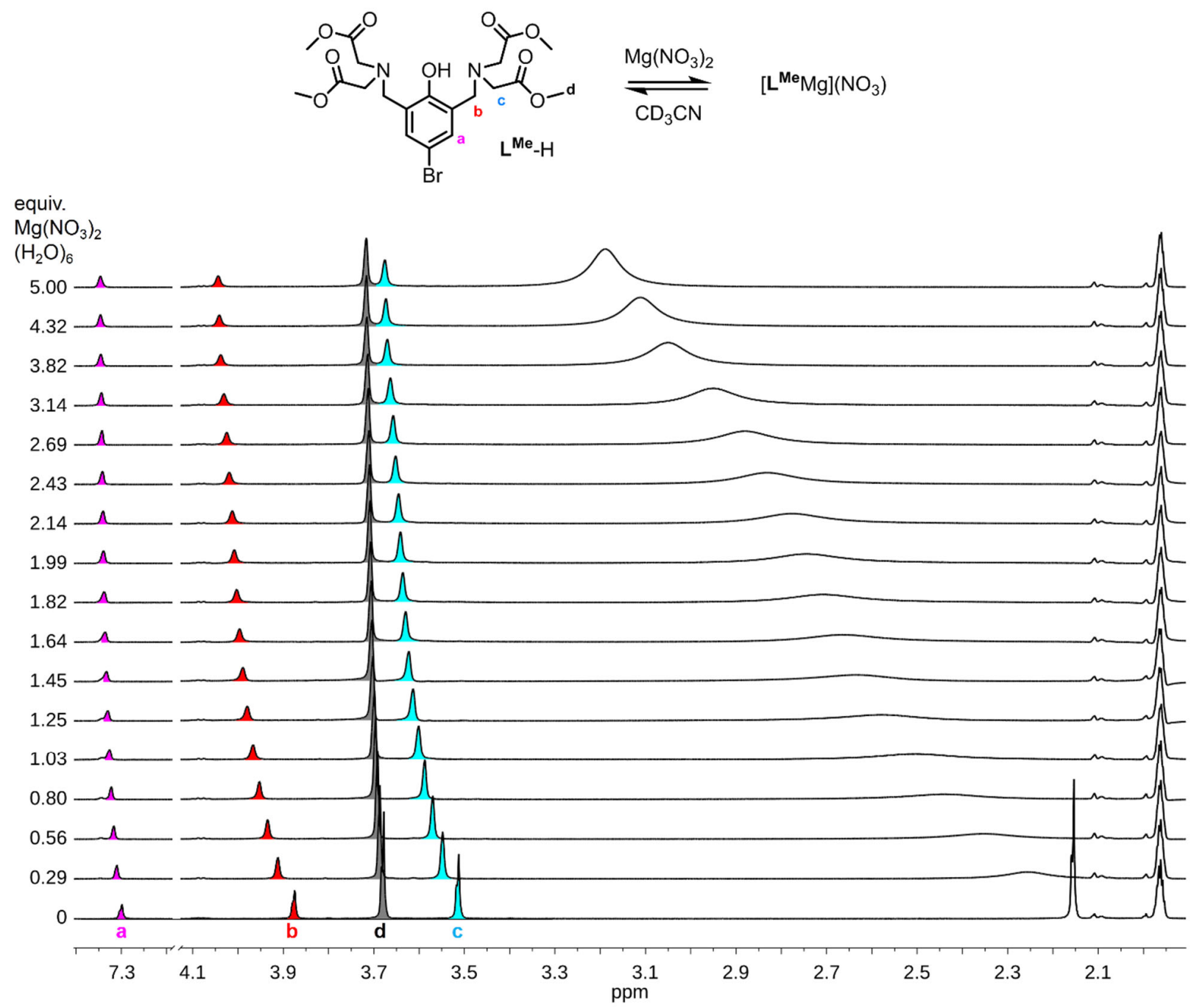

Figure S13: NMR titration ( $600 \mathrm{MHz})$ for the binding behavior of the methyl ester ligand $\mathbf{L}^{\mathrm{Me}}-\mathrm{H}$ upon addition of magnesium(II) nitrate hexahydrate in acetonitrile- $d_{3}$ at $25{ }^{\circ} \mathrm{C}$. The ligand concentration is $5 \mathrm{mM}$ and the titration is performed with dilution correction. 


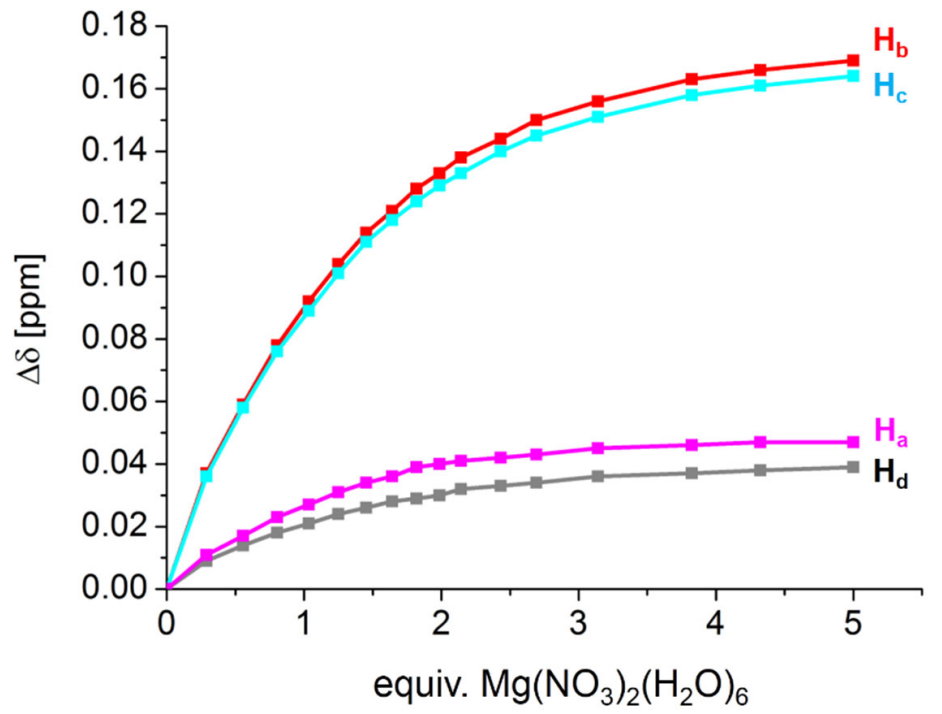

Figure S14: Titration data showing NMR shifts upon addition of magnesium(II) nitrate hexahydrate to the methyl ester ligand $\mathbf{L}^{\mathbf{M e}}$-H for the titration in Figure S13. 
3.6 Magnesium binding with $\mathrm{L}^{\mathrm{Et}}-\mathrm{H}$ :

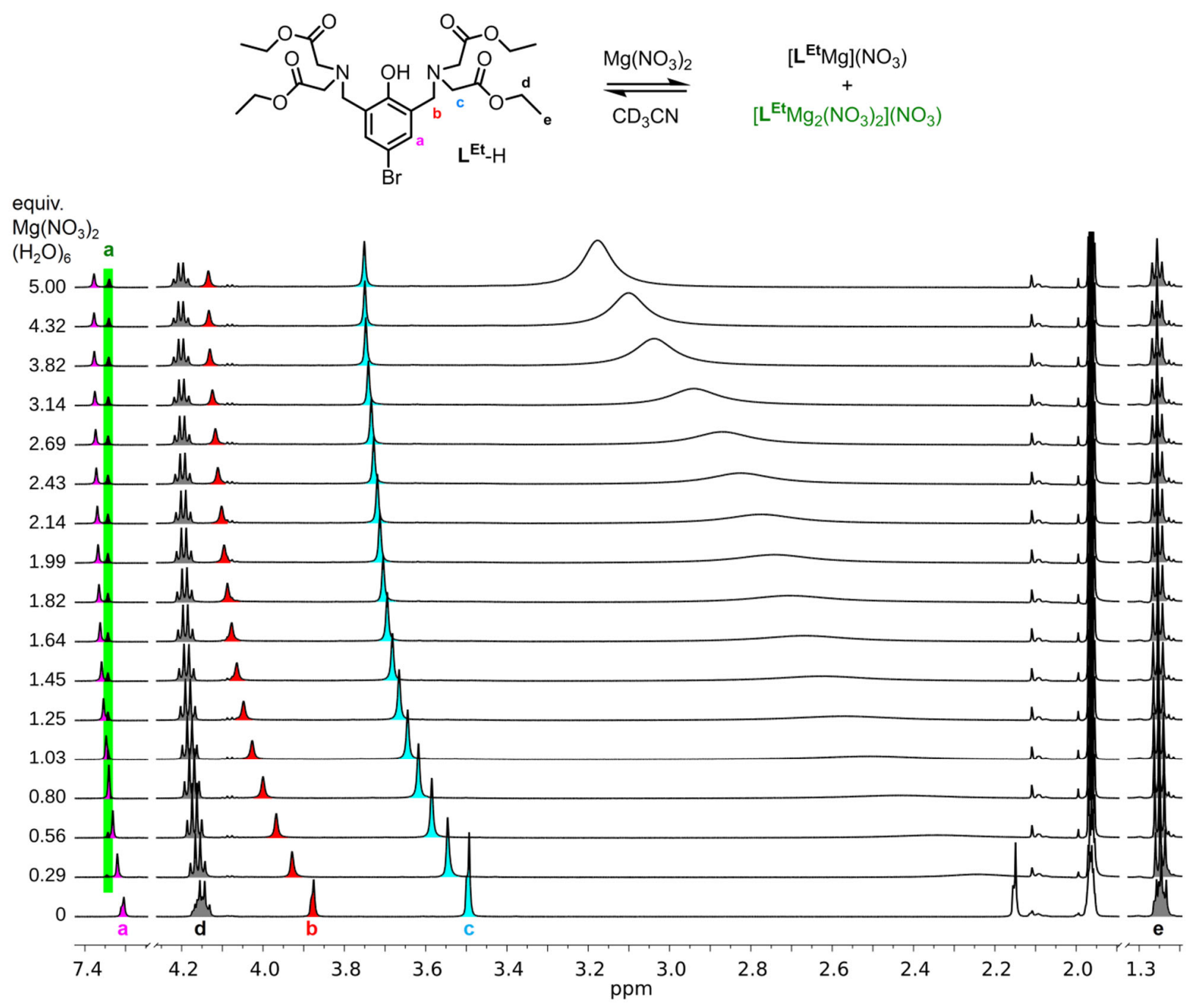

Figure S15: NMR titration ( $600 \mathrm{MHz}$ ) for the binding behavior of the ethyl ester ligand $\mathbf{L}^{\mathbf{E t}}$-H upon addition of magnesium(II) nitrate hexahydrate in acetonitrile- $d_{3}$ at $25{ }^{\circ} \mathrm{C}$. The ligand concentration is $5 \mathrm{mM}$ and the titration is performed with dilution correction. 


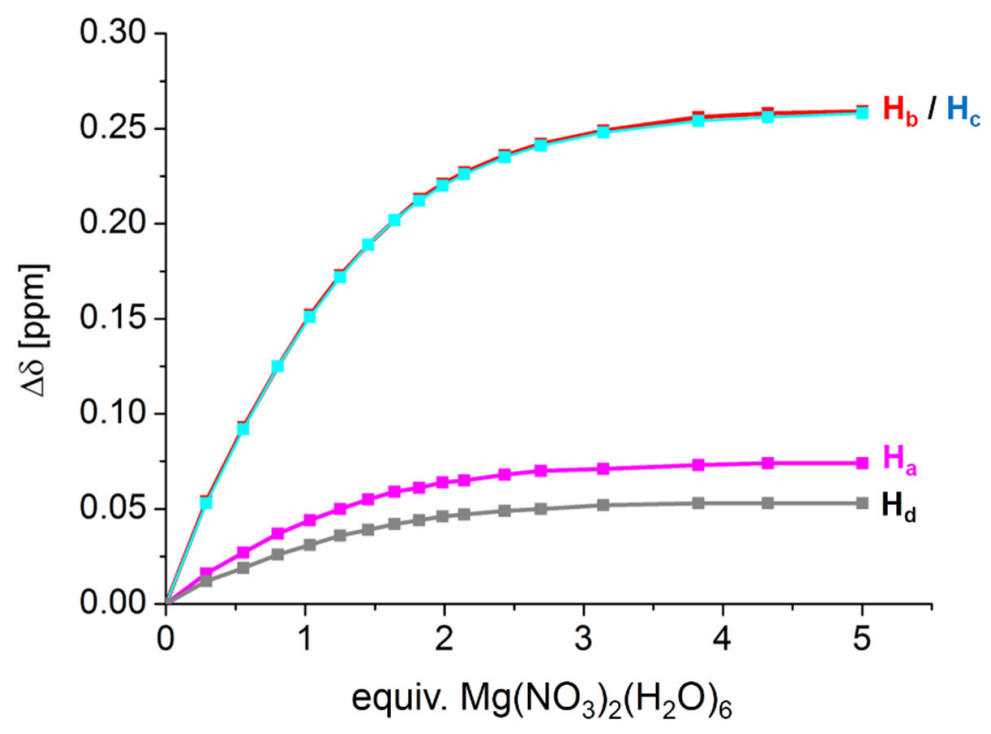

Figure S16: Titration data showing NMR shifts upon addition of magnesium(II) nitrate hexahydrate to the ethyl ester ligand $\mathbf{L}^{\mathrm{Et}}$-H for the titration in Figure S15.

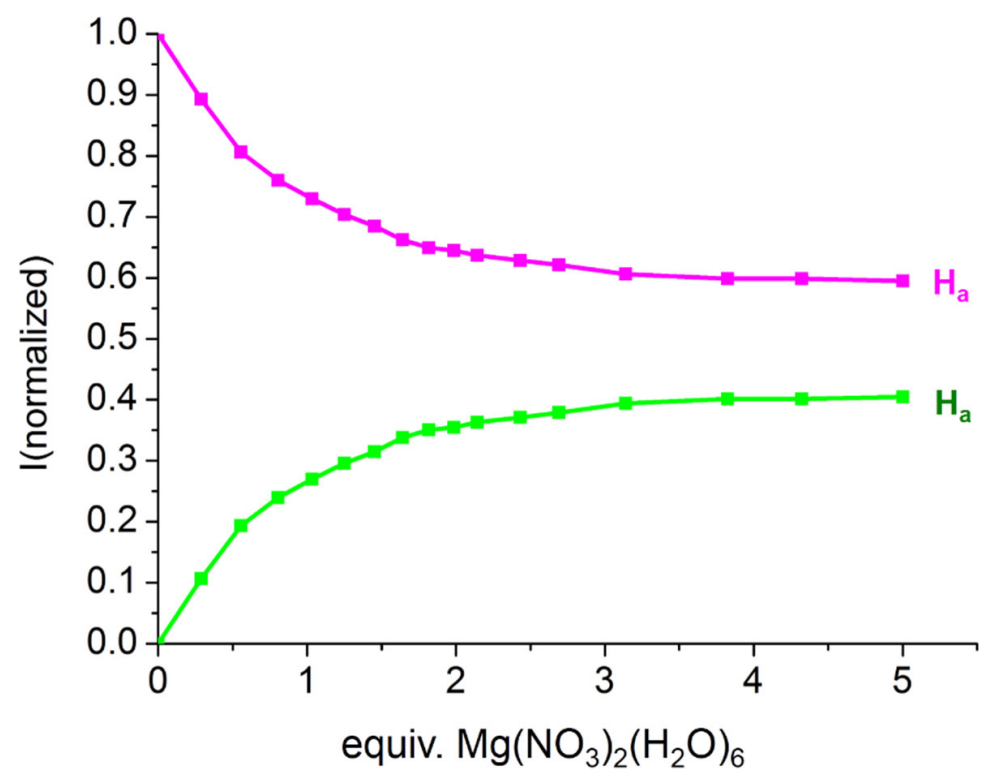

Figure S17: Normalized intensity changes observed upon addition of magnesium(II) nitrate hexahydrate to the ethyl ester ligand $\mathbf{L}^{\mathbf{E t}}$-H for the titration in Figure S15. 
3.7 Magnesium binding with $\mathrm{L}^{\mathrm{iPr}}-\mathrm{H}$ :

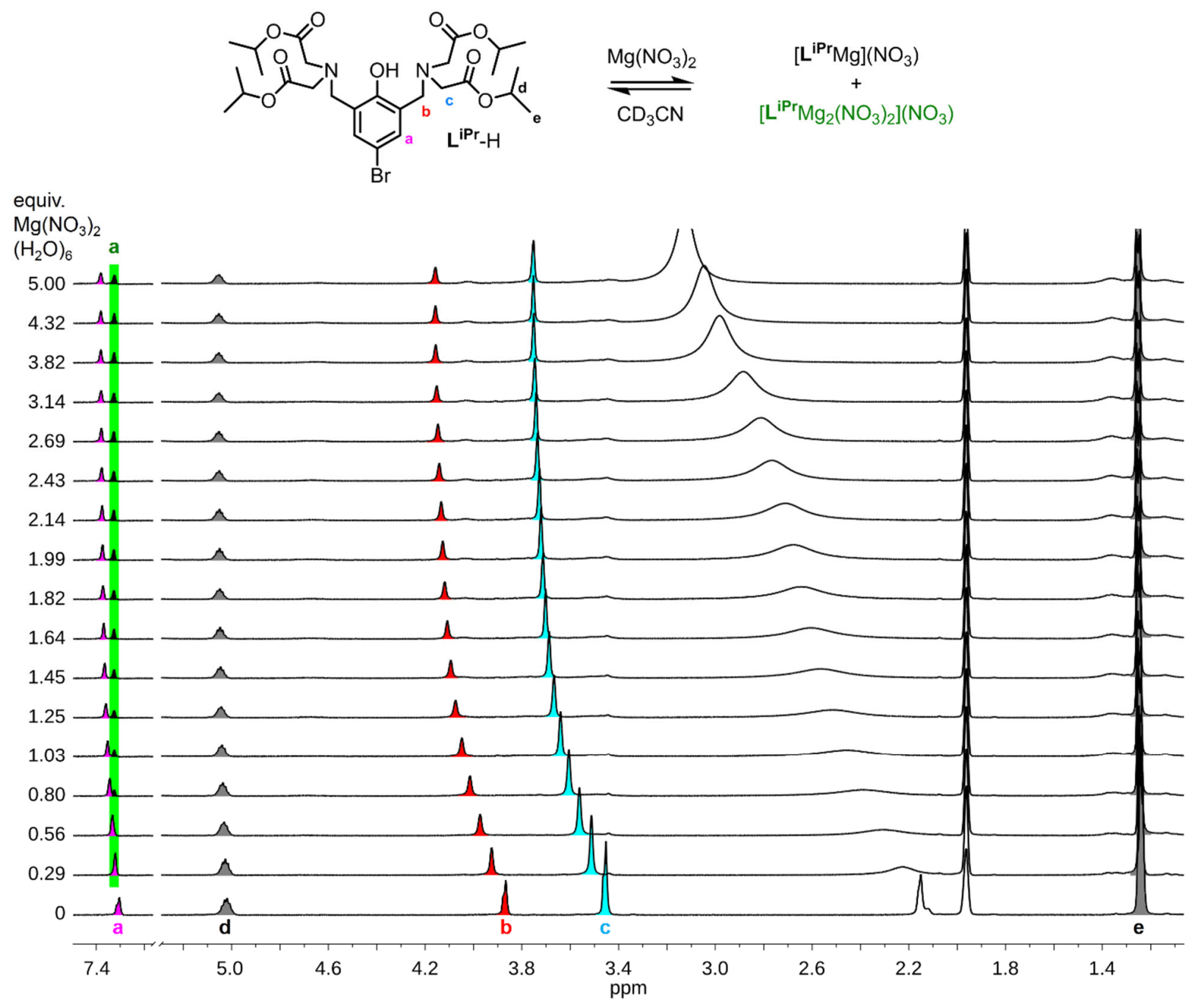

Figure S18: NMR titration (600 MHz) for the binding behavior of the isopropyl ester ligand $\mathbf{L}^{\mathbf{i P r}}$-H upon addition of magnesium(II) nitrate hexahydrate in acetonitrile- $d_{3}$ at $25{ }^{\circ} \mathrm{C}$. The ligand concentration is $5 \mathrm{mM}$ and the titration is performed with dilution correction. 


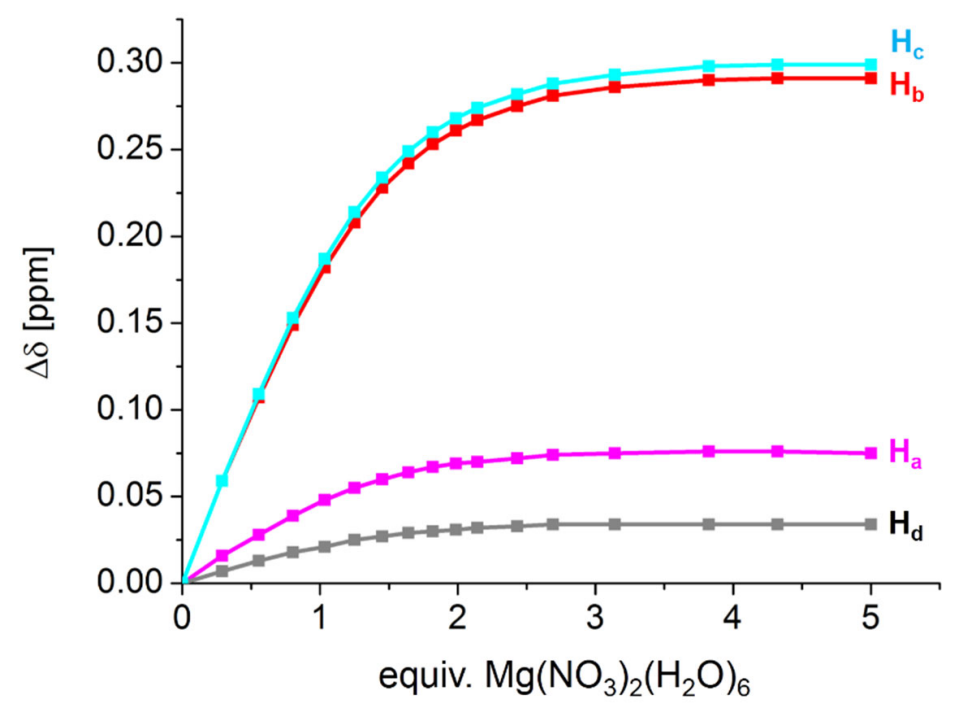

Figure S19: Titration data showing NMR shifts upon addition of magnesium(II) nitrate hexahydrate to the isopropyl ester ligand $\mathbf{L}^{\mathbf{i P r}}-\mathrm{H}$ for the titration in Figure S18.

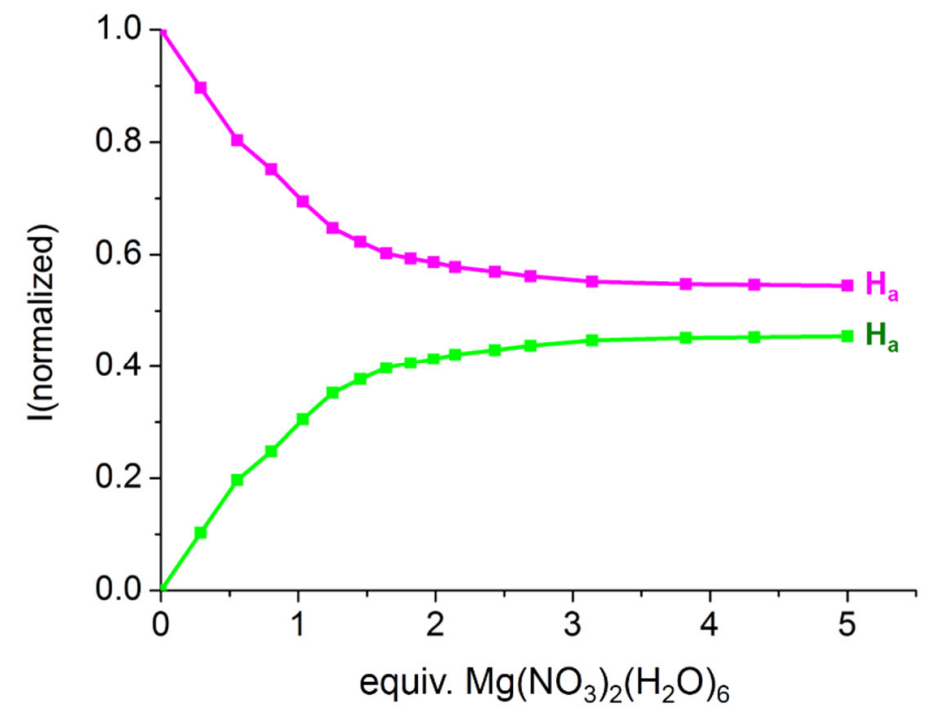

Figure S20: Normalized intensity changes observed upon addition of magnesium(II) nitrate hexahydrate to the isopropyl ester ligand $\mathbf{L}^{\mathbf{i P r}}-\mathrm{H}$ for the titration in Figure S18. 

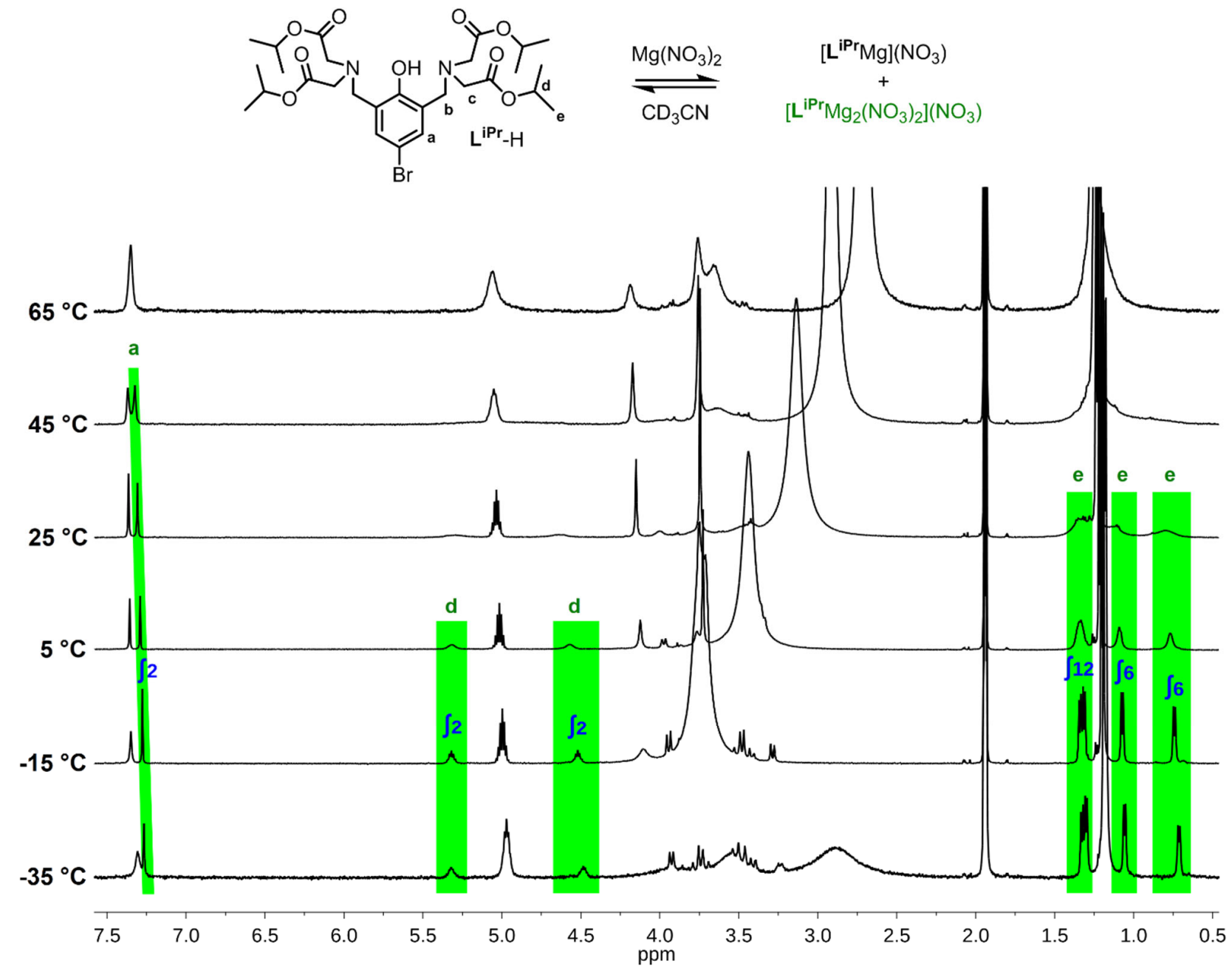

Figure S21: VT NMR spectra $(500 \mathrm{MHz})$ of isopropyl ester ligand $\mathbf{L}^{\mathbf{i P r}}-\mathrm{H}(5 \mathrm{mM})$ with 5 equiv. magnesium(II) nitrate hexahydrate in acetonitrile- $d_{3}$. Very broad regions appear in the aliphatic region in the spectrum at $25^{\circ} \mathrm{C}$. These broad regions sharpen up with decreasing temperature and show splitted NMR signals. Proton $\mathrm{H}_{\mathrm{a}}, \mathrm{H}_{\mathrm{d}}$ and $\mathrm{H}_{\mathrm{e}}$ show matching integrals while proton $\mathrm{Hb}_{\mathrm{b}}$ and $\mathrm{H}_{\mathrm{c}}$ are overlapping with other signals between 4.0 and $2.5 \mathrm{ppm}$. 


\subsection{Magnesium binding with $\mathrm{L}^{\mathrm{Bz}}-\mathrm{H}$ :}

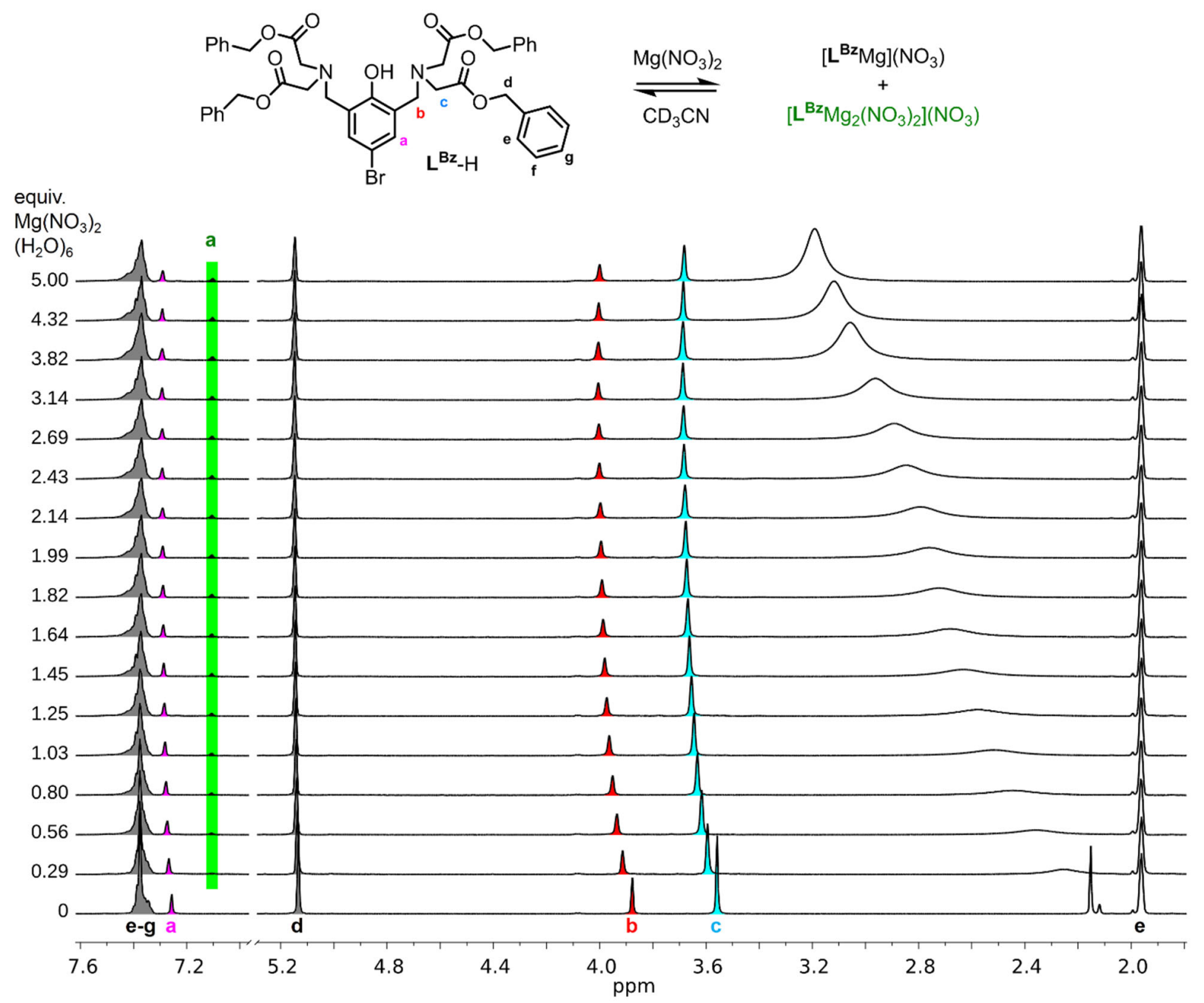

Figure S22: NMR titration ( $600 \mathrm{MHz}$ ) for the binding behavior of the benzyl ester ligand $\mathbf{L}^{\mathbf{B z}}-\mathrm{H}$ upon addition of magnesium(II) nitrate hexahydrate in acetonitrile- $d_{3}$ at $25^{\circ} \mathrm{C}$. The ligand concentration is $5 \mathrm{mM}$ and the titration is performed with dilution correction. 


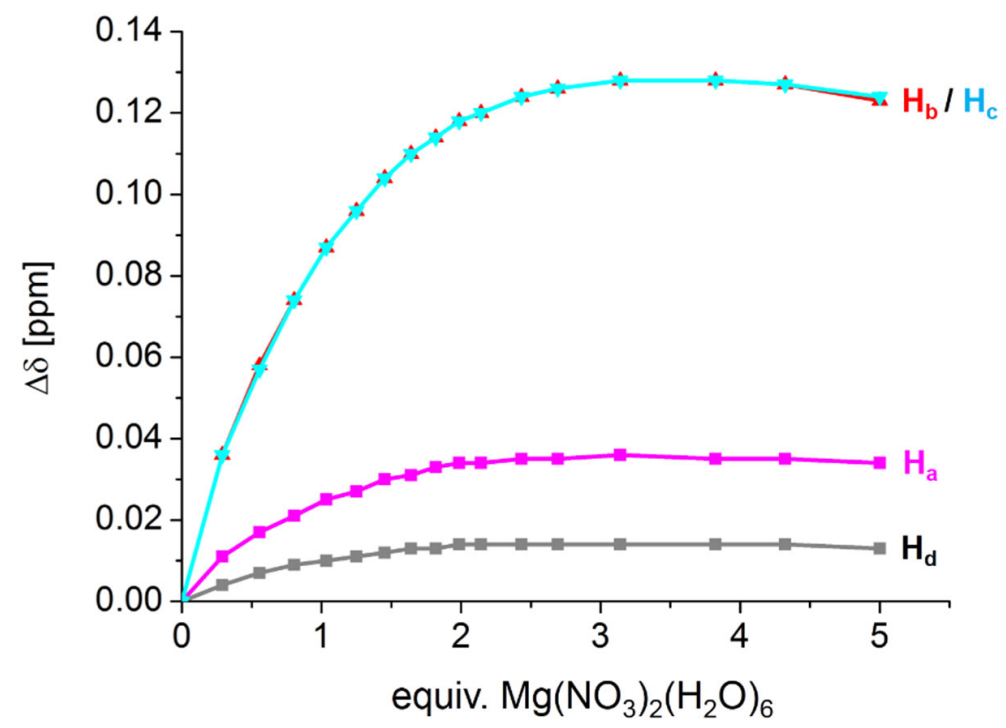

Figure S23: Titration data showing NMR shifts upon addition of magnesium(II) nitrate hexahydrate to the benzyl ester ligand $\mathbf{L}^{\mathbf{B z}}$-H for the titration in Figure S22.

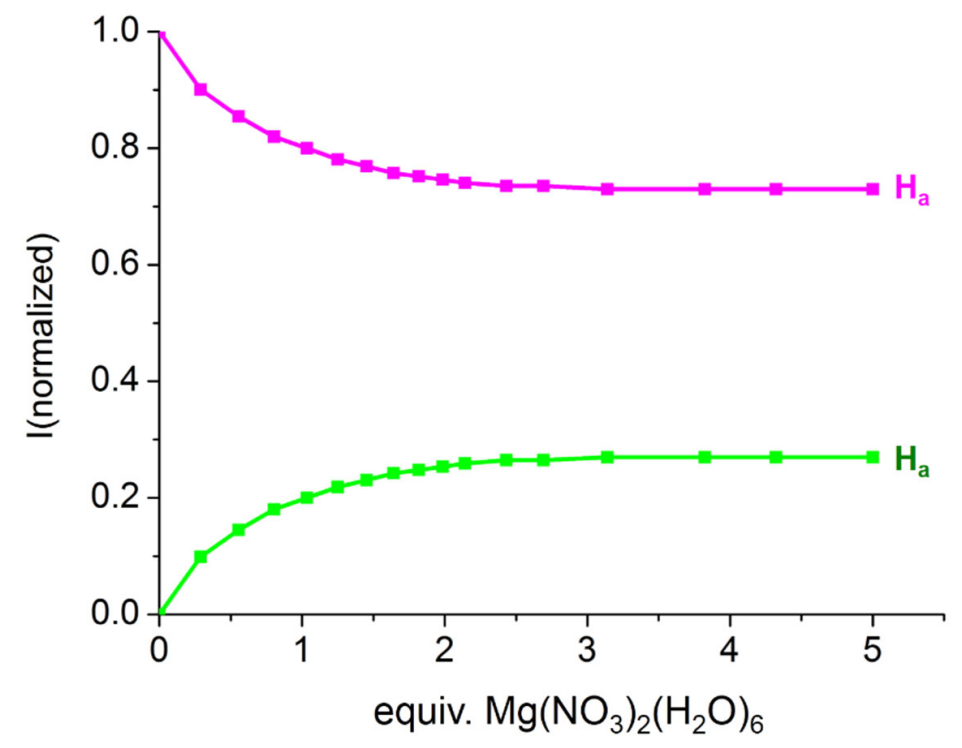

Figure S24: Normalized intensity changes observed upon addition of magnesium(II) nitrate hexahydrate to the benzyl ester ligand $\mathbf{L}^{\mathbf{B z}}$-H for the titration in Figure S22. 


\subsection{Anion exchange for $\left[\mathrm{L}^{\mathrm{DPA}} \mathrm{Mg}_{2}\left(\mu_{2}-\mathrm{NO}_{3}\right)_{2}\right]^{+}$with (TBA)OAc:}
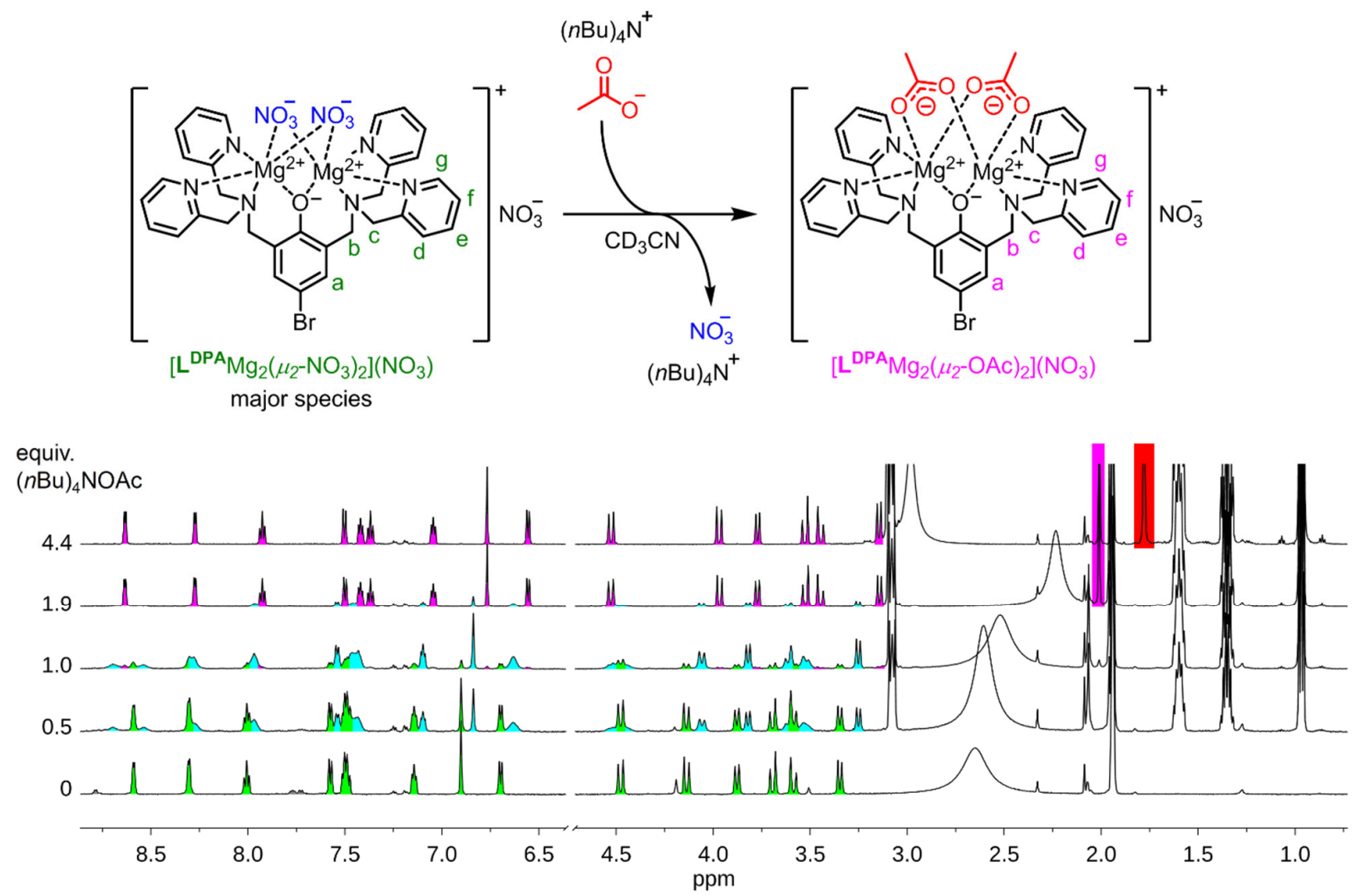

Figure S25: Anion-exchange of the bridging nitrate anions by acetate upon addition of TBA acetate to the magnesium complex $\left[\mathbf{L}^{\mathbf{D P A}} \mathrm{Mg}_{2}\left(\mu_{2}-\mathrm{NO}_{3}\right)_{2}\right]^{+}$(green) in acetonitrile- $d_{3}(5 \mathrm{mM}$ solution, $600 \mathrm{MHz}$, $25^{\circ} \mathrm{C}$ ). Signals for intermediate species are shown in cyan, while the acetate-bridged complex $\left[\mathbf{L}^{\text {DPA }} \mathrm{Mg}_{2}\left(\mu_{2}-\mathrm{OAc}\right)_{2}\right]^{+}$is marked in pink. The signal highlighted with a pink box is the bridging acetate species and the signal shown within the red box the one of the unbound additional acetate. 

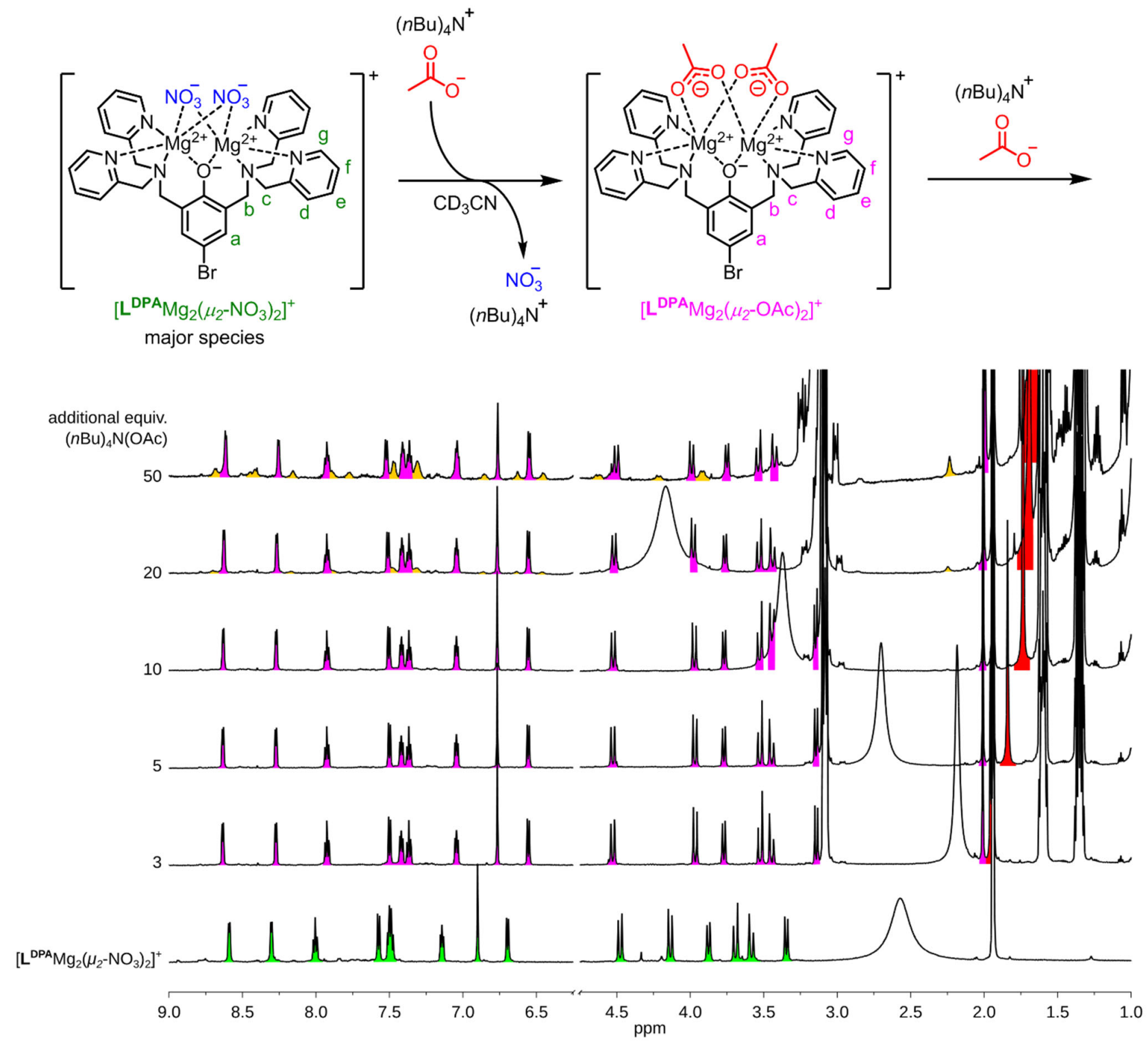

Figure S26: Addition of an excess of TBA acetate to the acetate bridged bimetallic magnesium complex ( $5 \mathrm{mM}$ solution, $600 \mathrm{MHz}, 25^{\circ} \mathrm{C}$ ). After the addition of 20 equivalents of TBA acetate a set of new signals emerge (marked in gold). These signals are an indication for a possible change in the bridging mode of acetate since a new singlet is also found in the aliphatic region. However, the acetate bridged complex (pink) is very stable and the new species is only observed as a minor species. 

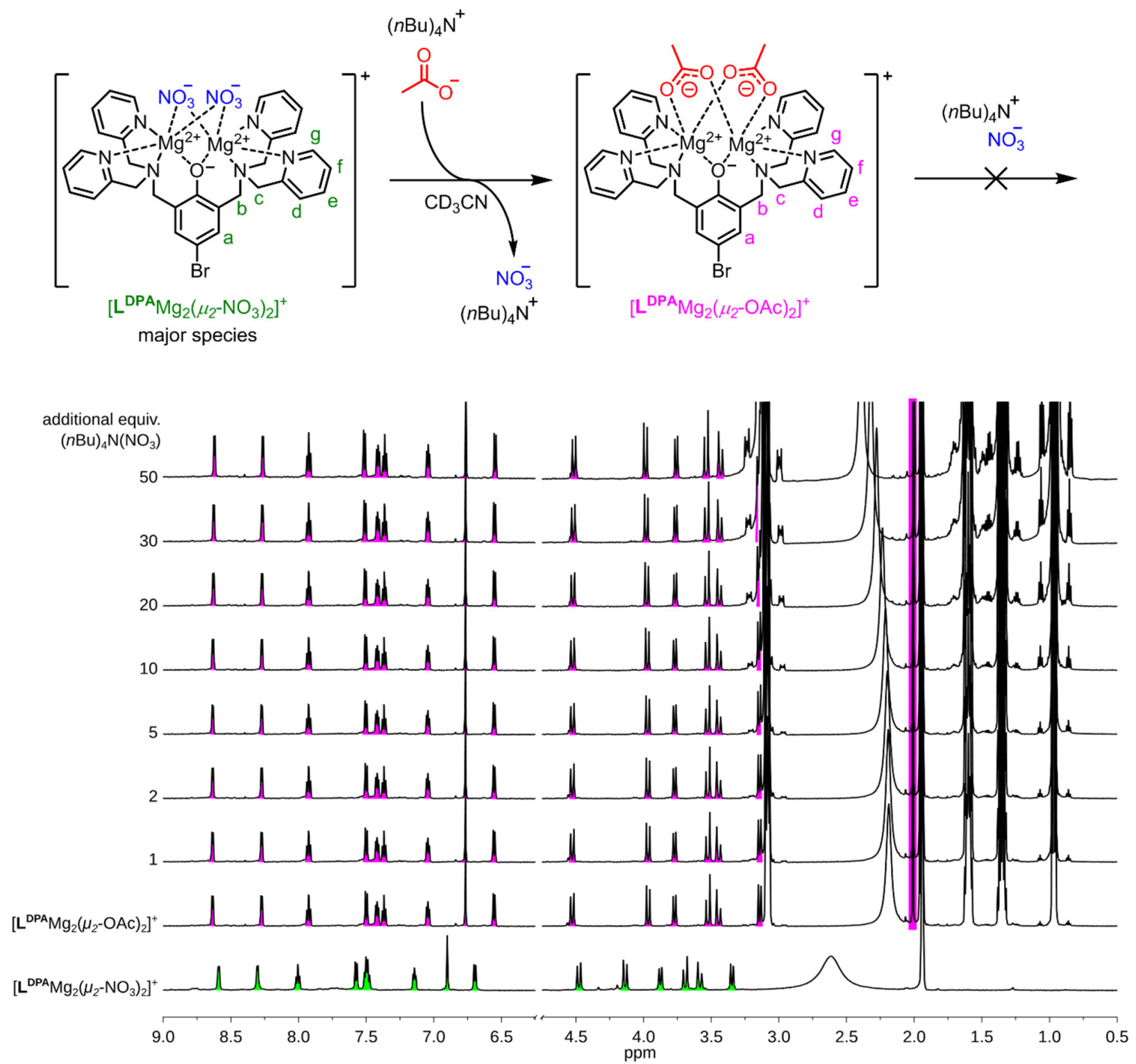

Figure S27: Addition of an excess of TBA nitrate to the acetate bridged bimetallic magnesium complex ( $5 \mathrm{mM}$ solution, $600 \mathrm{MHz}, 25^{\circ} \mathrm{C}$ ). No exchange of the bridging acetate anions is observed even after the addition of 50 equivalents of TBA nitrate. 


$$
\mathrm{L}^{\mathrm{DPA}-\mathrm{H}} \stackrel{\mathrm{Mg}(\mathrm{OAc})_{2}\left(\mathrm{H}_{2} \mathrm{O}\right)_{4}}{\mathrm{CD}_{3} \mathrm{CN}}\left[\mathrm{L}^{\mathrm{DPA}} \mathrm{Mg}_{2}\left(\mu_{2}-\mathrm{OAc}\right)_{2}\right]^{+}
$$
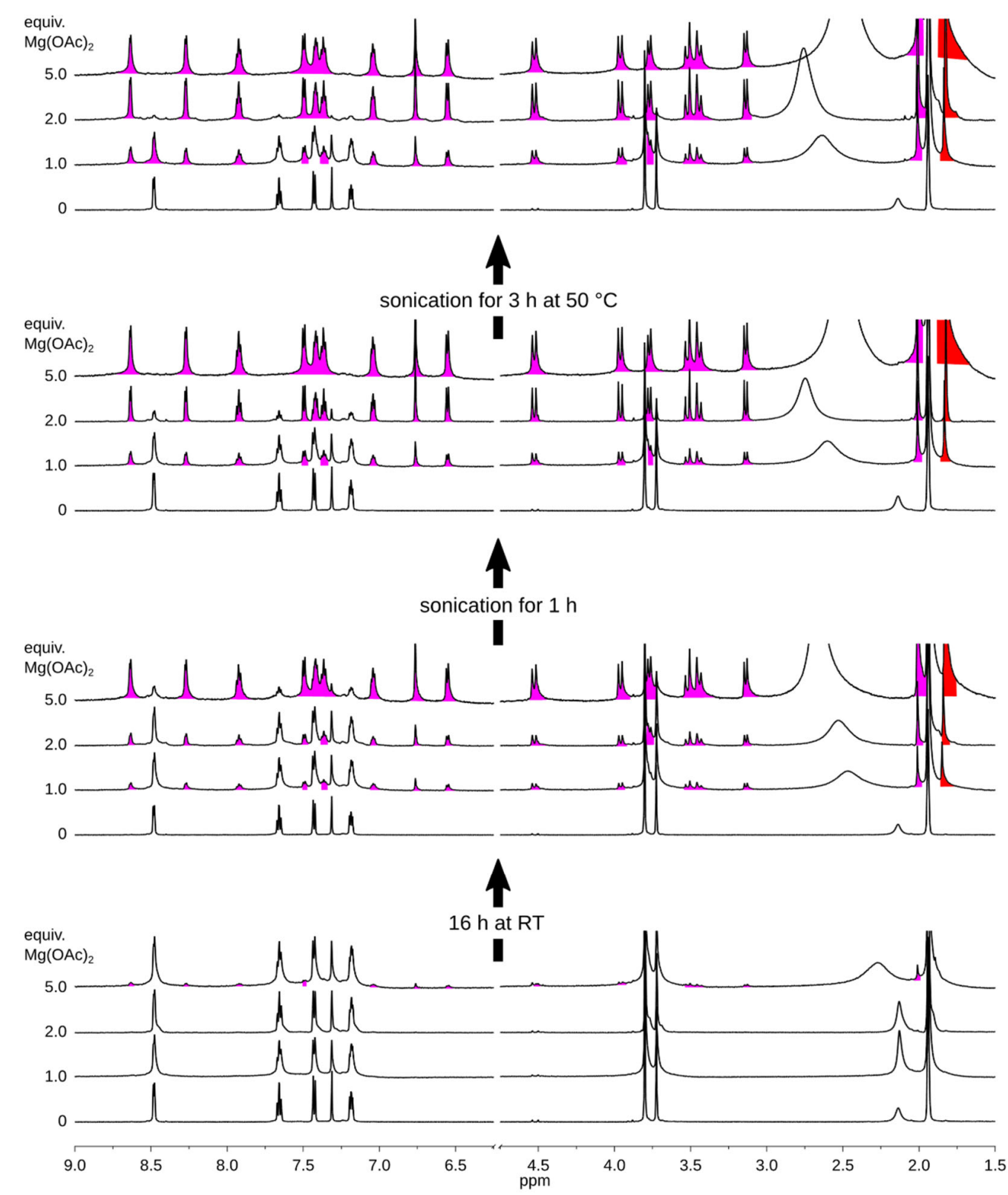

Figure S28: Attempted titration of $\mathbf{L}^{\mathbf{D P A}}-\mathrm{H}$ with magnesium acetate tetrahydrate $(5 \mathrm{mM}, 600 \mathrm{MHz}$, $\mathrm{CD}_{3} \mathrm{CN}, 25^{\circ} \mathrm{C}$ ). The magnesium acetate salt is nearly insoluble in $\mathrm{CD}_{3} \mathrm{CN}$. A normal titration is impossible as a result of this. Magnesium acetate tetrahydrate was balanced into NMR tubes as solid. A solution of $\mathbf{L}^{\mathbf{D P A}}-\mathrm{H}$ ( $5 \mathrm{mM}$ in $\mathrm{CD}_{3} \mathrm{CN}$ ) was added to the NMR tubes to obtain the stoichiometries of the three steps. External force was applied to obtain full complexation in the tubes with two and five equivalents of magnesium acetate salt. The free acetate signal is marked in red in the aliphatic region. 

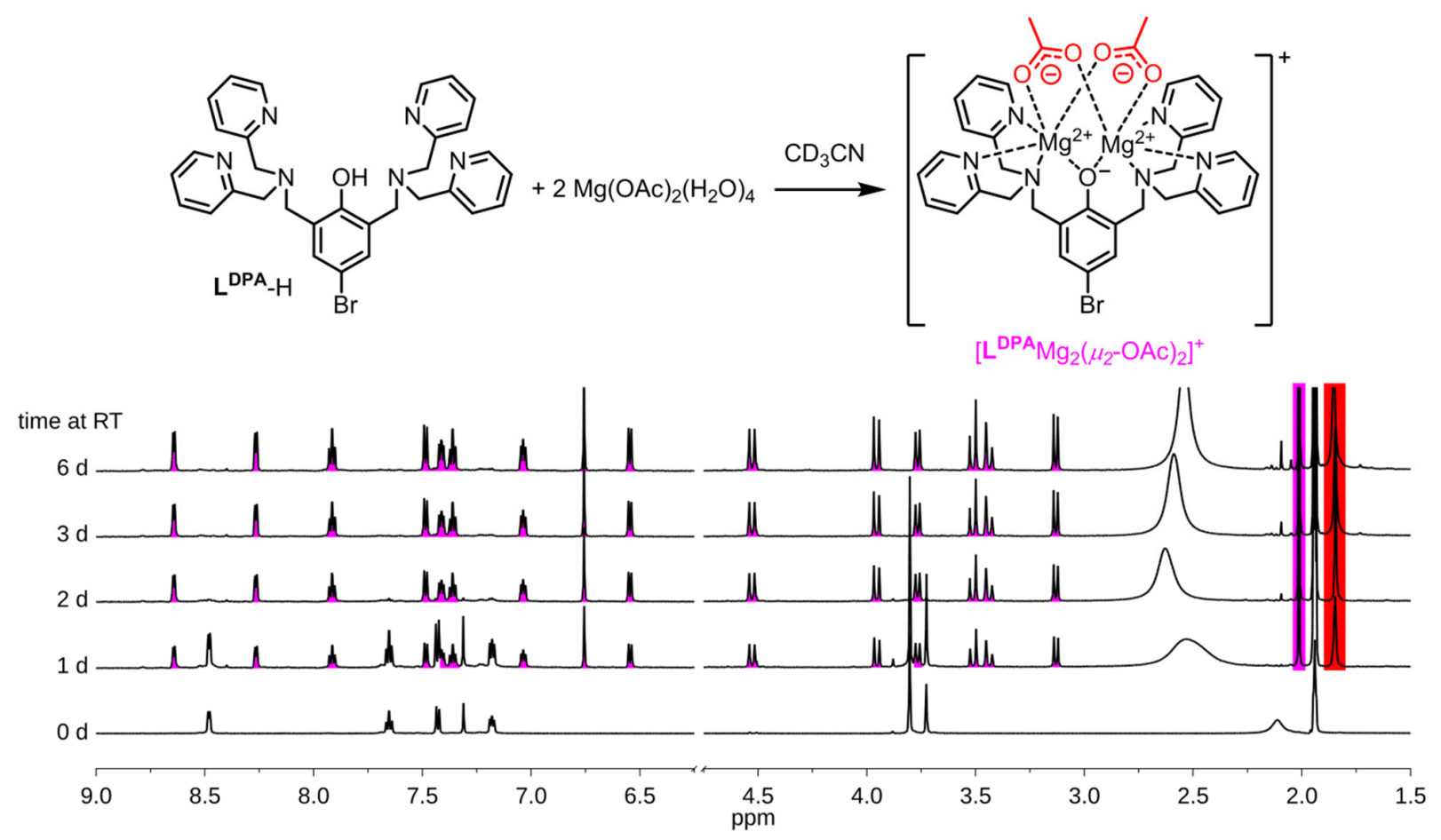

Figure S29: Time dependent complexation of $\mathbf{L}^{\mathbf{D P A}}-\mathrm{H}$ with magnesium acetate tetrahydrate $(5 \mathrm{mM}, 600$ $\mathrm{MHz}, \mathrm{CD}_{3} \mathrm{CN}, 25^{\circ} \mathrm{C}$ ). Two equivalents of magnesium acetate tetrahydrate was added to a NMR tube. $\mathbf{L}^{\text {DPA }}-\mathrm{H}$ in $\mathrm{CD}_{3} \mathrm{CN}$ ( 1 equiv., $5 \mathrm{mM}$ ) was added to the tube and the complexation was monitored over time. Signals of the magnesium acetate complex emerge after one day and the complexation is complete after three days. The signal of free acetate is marked in red. 


\subsection{Anion exchange for $\left[\mathrm{LPA}^{\mathrm{DPA}} \mathrm{Mg}_{2}\left(\mu_{2}-\mathrm{NO}_{3}\right)_{2}\right]^{+}$with $(\mathrm{TBA}) \mathrm{H}_{2} \mathrm{PO}_{4}$ :}
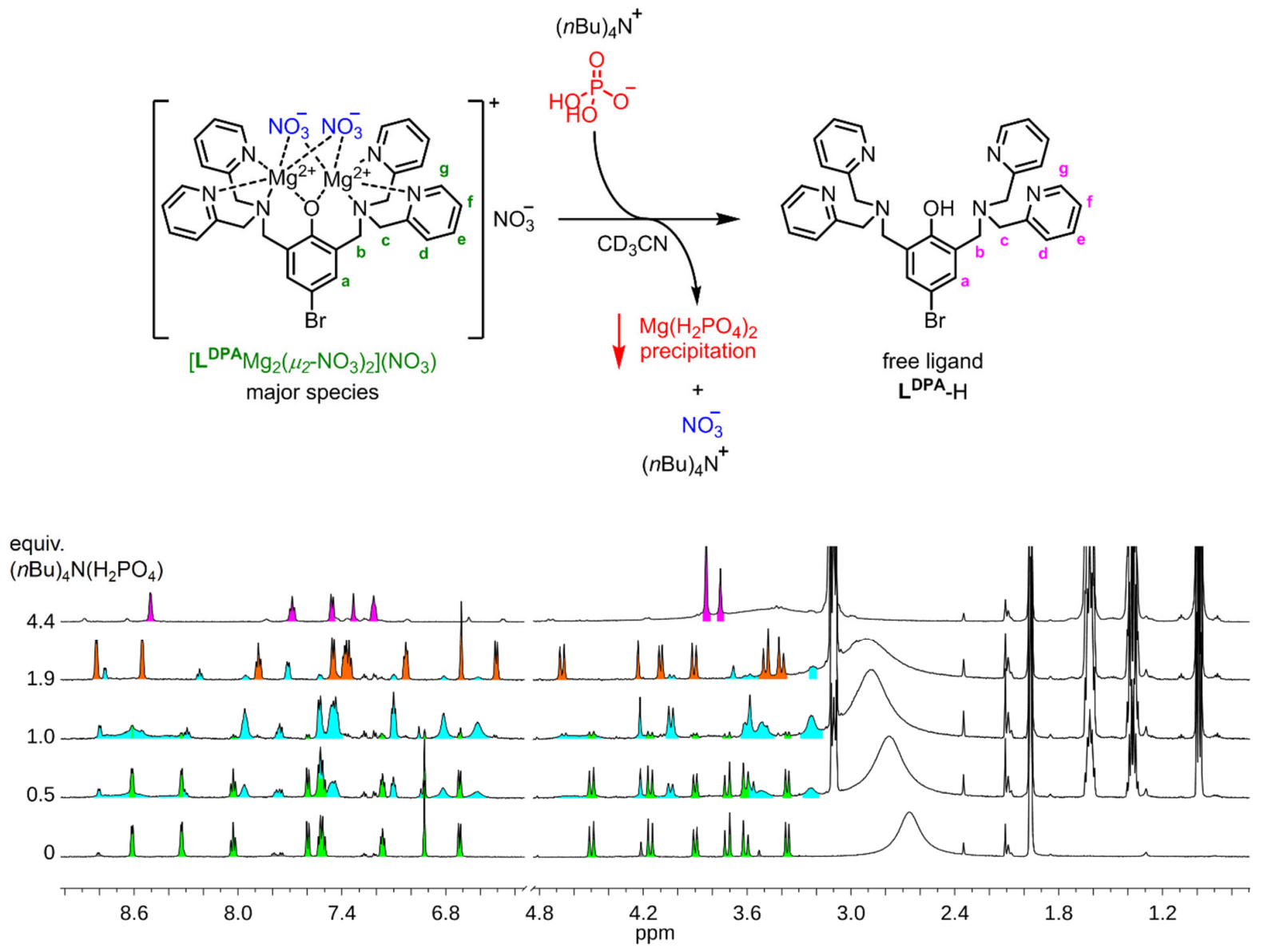

Figure S30: Anion-exchange test of the bridging nitrate anions upon the addition of TBA dihydrogen phosphate to the magnesium complex $\left[\mathbf{L}^{\mathbf{D P A}} \mathrm{Mg}_{2}\left(\mu_{2}-\mathrm{NO}_{3}\right)_{2}\right]^{+}$(green) in acetonitrile- $d_{3}(5 \mathrm{mM}$ solution, $600 \mathrm{MHz}, 25^{\circ} \mathrm{C}$ ). Signals for the intermediate species are shown in cyan. Another intermediate assumed to be a complex with a bridging phosphate is shown in orange. This phosphate-bridged species is not stable upon addition of an excess of the phosphate salt and the formation of an inorganic precipitate is observed. The NMR shows clearly the recovery of the free ligand $\mathbf{L}^{\mathbf{D P A}}-\mathbf{H}$ and thus the precipitate is assumed to be magnesium phosphate. Further addition of TBA dihydrogen phosphate was stopped at this point. 

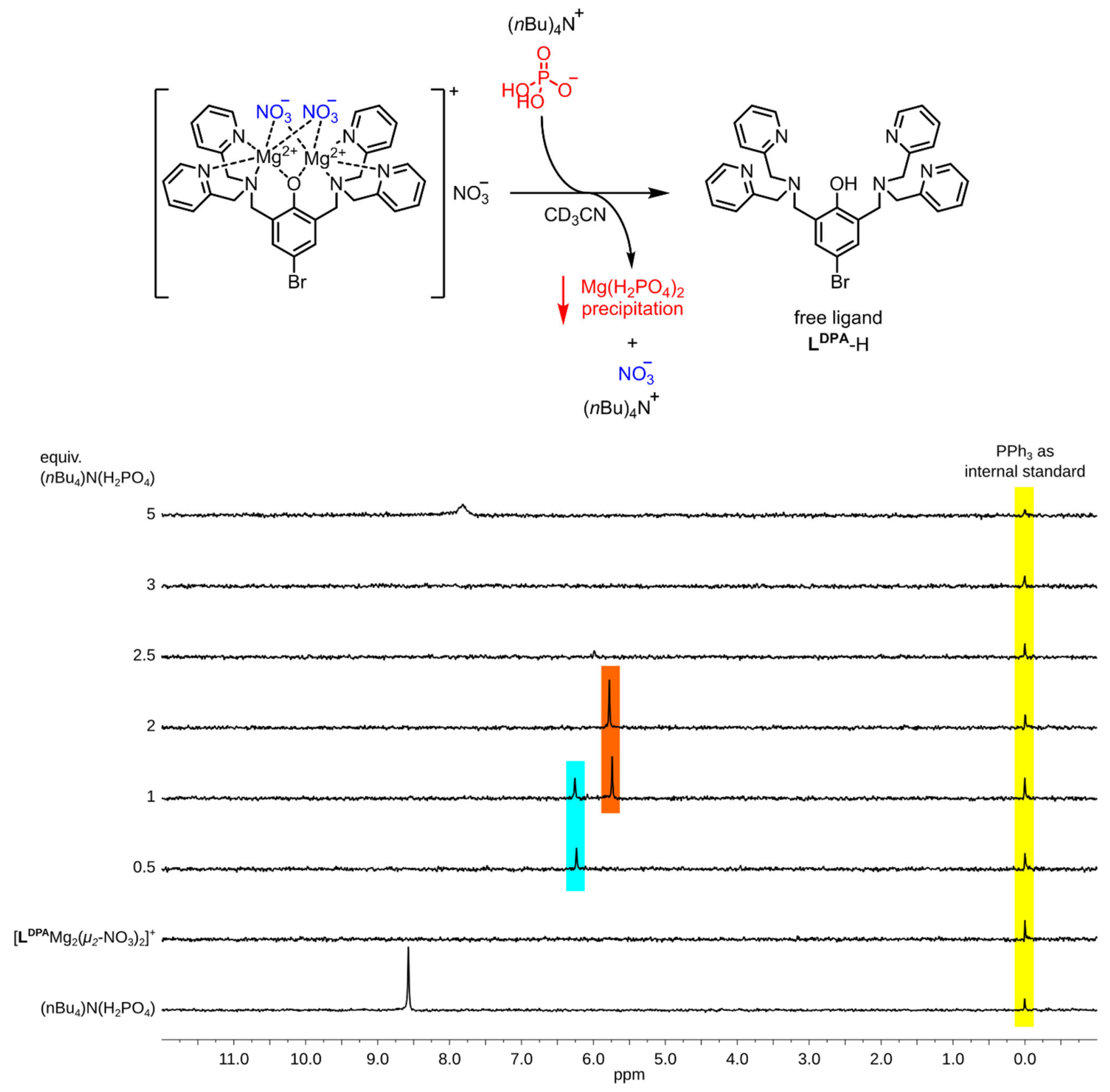

Figure S31: ${ }^{31} \mathrm{P}$ NMR $\left(162 \mathrm{MHz}, \mathrm{CD}_{3} \mathrm{CN}, 5 \mathrm{mM}, 25^{\circ} \mathrm{C}\right)$ showing the different phosphor species upon addition of tetrabutylammonium dihydrogen phosphate. Triphenylphosphine was added as a standard used for referencing the spectra to $0 \mathrm{ppm}$ for $\mathrm{PPh}_{3}$. Two different phosphor species are observed before significant precipitation occurs which is line with the ${ }^{1} \mathrm{H}$ NMR titration. 


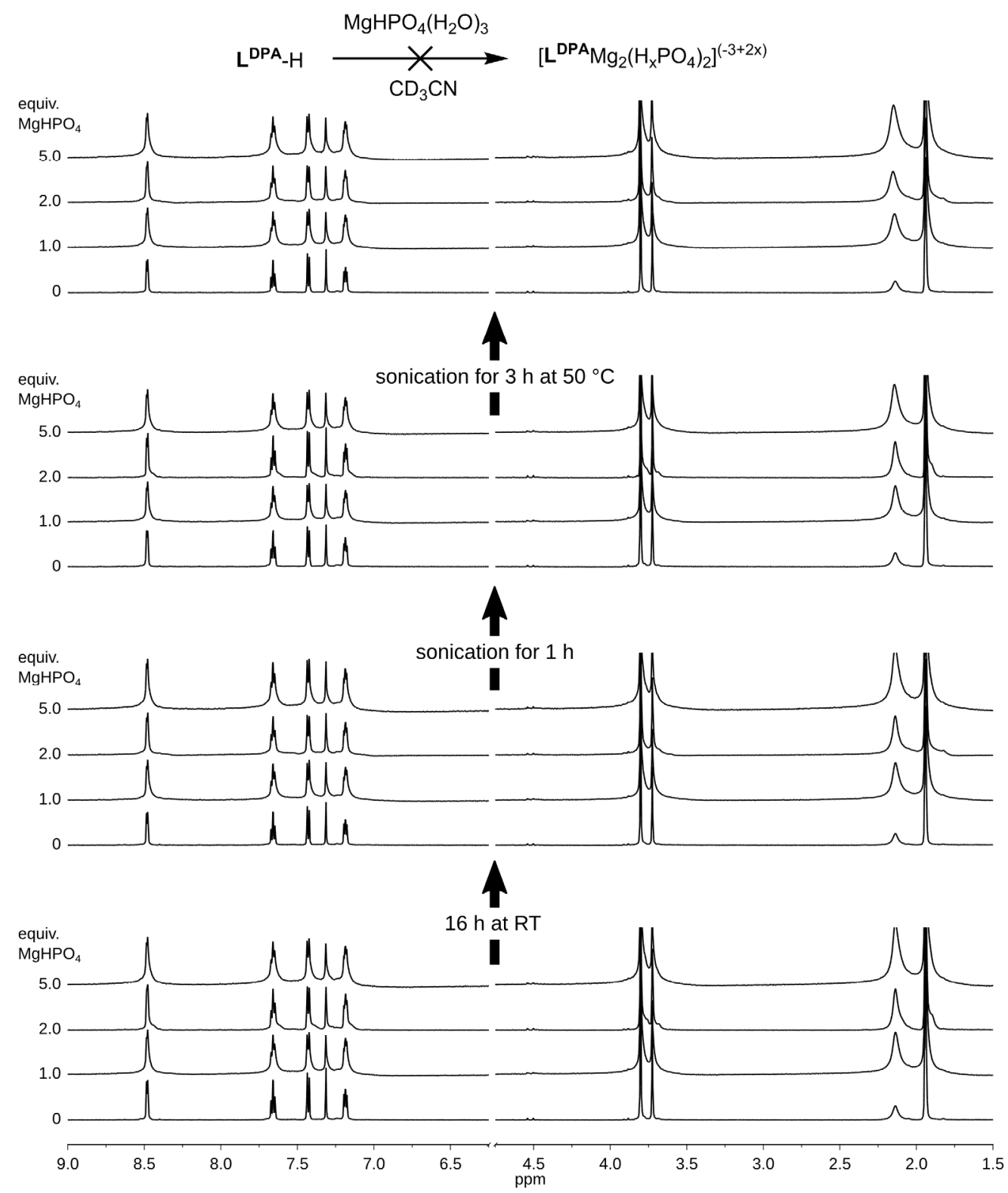

Figure S32: Attempted titration of $\mathbf{L}^{\mathbf{D P A}}-\mathrm{H}$ with magnesium hydrogen phosphate trihydrate $(5 \mathrm{mM}, 600$ $\mathrm{MHz}, \mathrm{CD}_{3} \mathrm{CN}, 25^{\circ} \mathrm{C}$ ). The magnesium hydrogen phosphate salt seems to be insoluble in $\mathrm{CD}_{3} \mathrm{CN}$. A normal titration is impossible as a result of this. Magnesium hydrogen phosphate trihydrate was balanced into NMR tubes as solid. A solution of $\mathbf{L}^{\text {DPA }}-\mathrm{H}\left(5 \mathrm{mM}\right.$ in $\left.\mathrm{CD}_{3} \mathrm{CN}\right)$ was added to the NMR tubes to obtain the stoichiometries of the three steps. No complex formation was observed even after applying external force. 


\subsection{Anion exchange for $\left[\mathrm{L}^{\mathrm{DPA}} \mathrm{Mg}_{2}\left(\mu_{2}-\mathrm{NO}_{3}\right)_{2}\right]^{+}$with $(\mathrm{TBA})_{3} \mathrm{HP}_{2} \mathrm{O}_{7}$ :}
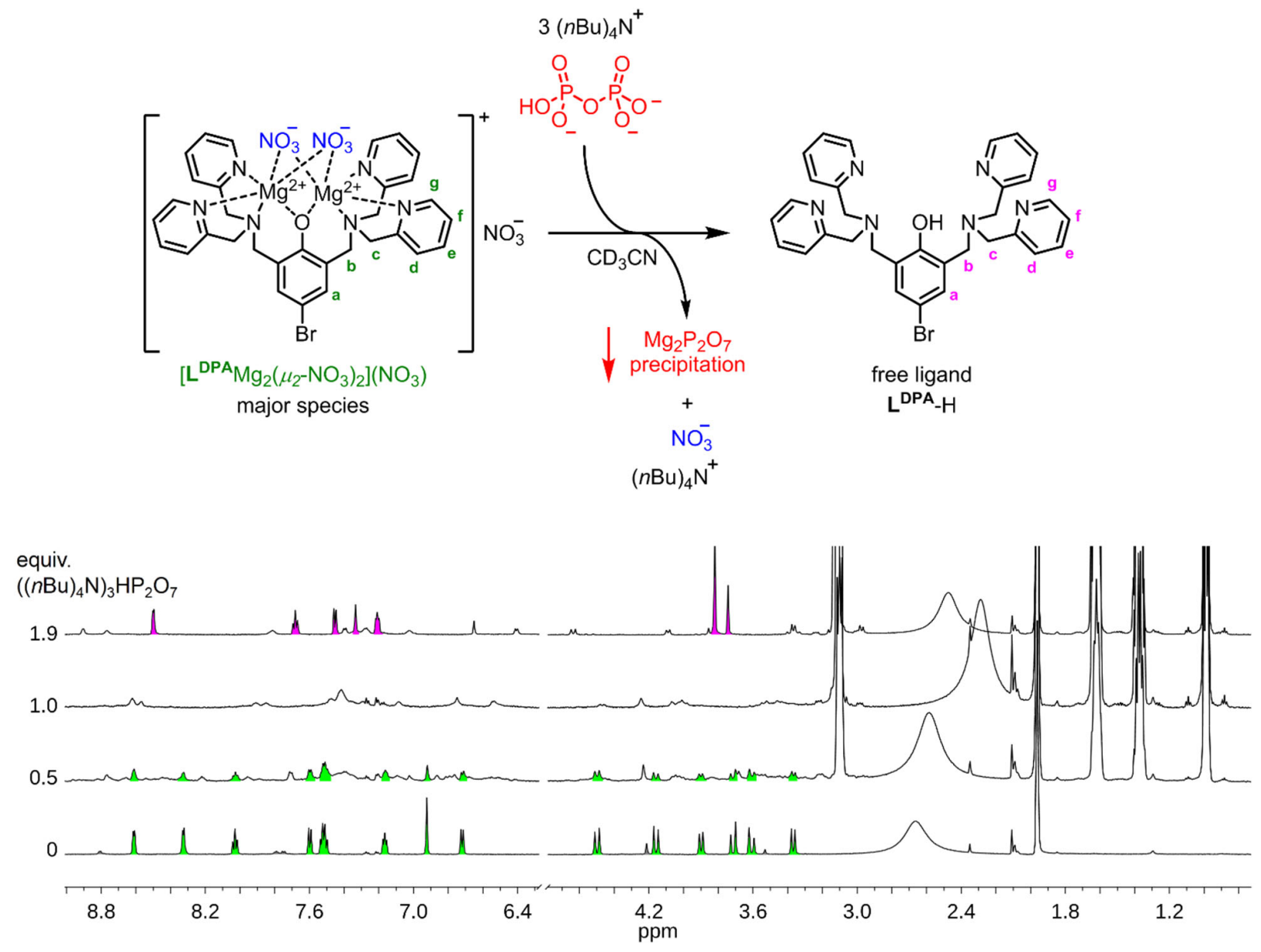

Figure S33: Anion-exchange test of the bridging nitrate anions by pyrophosphate upon addition of TBA hydrogen pyrophosphate to the magnesium complex $\left[\mathbf{L}^{\mathbf{D P A}} \mathrm{Mg}_{2}\left(\mu_{2}-\mathrm{NO}_{3}\right)_{2}\right]^{+}$(green) in acetonitrile- $d_{3}$ $\left(5 \mathrm{mM}\right.$ solution, $600 \mathrm{MHz}, 25^{\circ} \mathrm{C}$ ). Broad intermediate species are observed upon addition of the salt. Signals indicating a pyrophosphate-bridged species cannot be seen at any point and the formation of a precipitate is observed. The NMR shows clearly the recovery of the free ligand $\mathbf{L}^{\mathbf{D P A}}-\mathbf{H}$. Thus the precipitate is assumed to be magnesium pyrophosphate. Addition of TBA hydrogen pyrophosphate was stopped at this point. 
3.12 IR spectra of the magnesium complexes of $L^{D P A}$ and $L^{E t}$ :

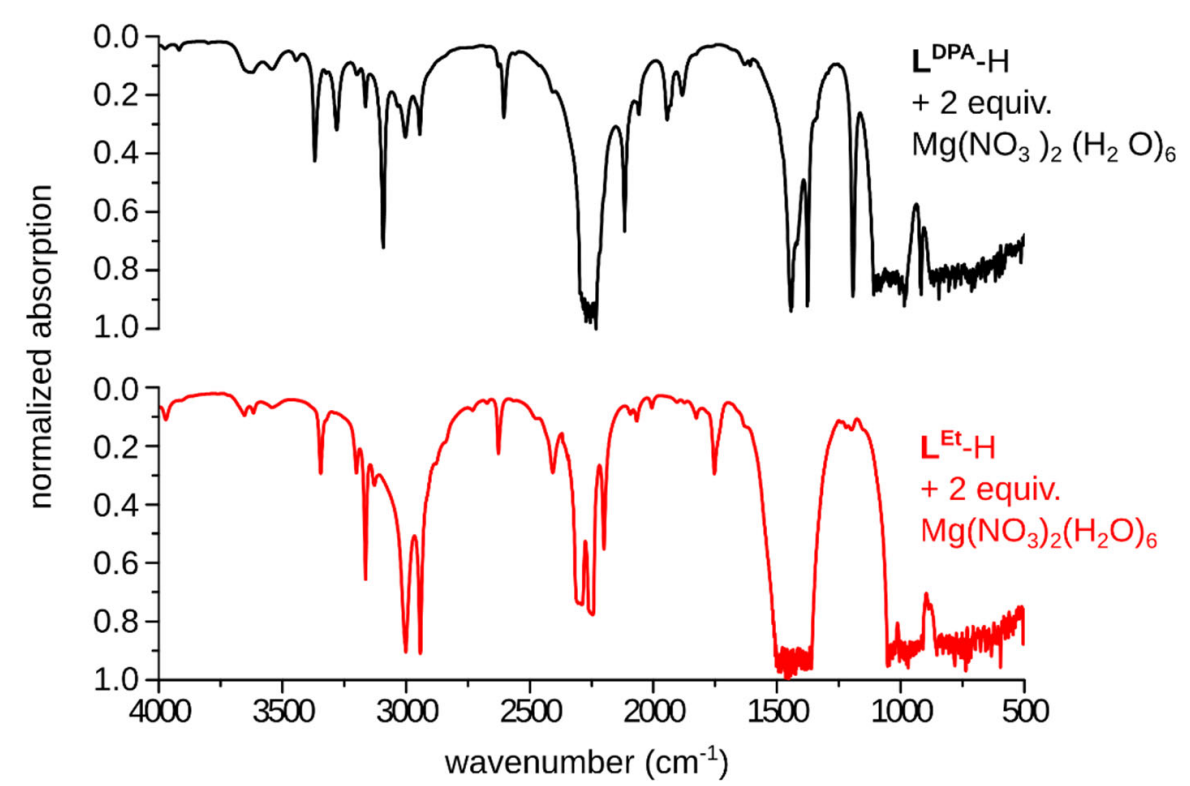

Figure S34: Exemplary solution IR spectra of the magnesium complexes of $\mathbf{L}^{\mathbf{D P A}}$ and $\mathbf{L}^{\mathbf{E t}}$ in $\mathrm{CD}_{3} \mathrm{CN}$. 


\section{Electrospray Ionization Mass Spectrometry for the Bimetallic Magnesium Complexes}

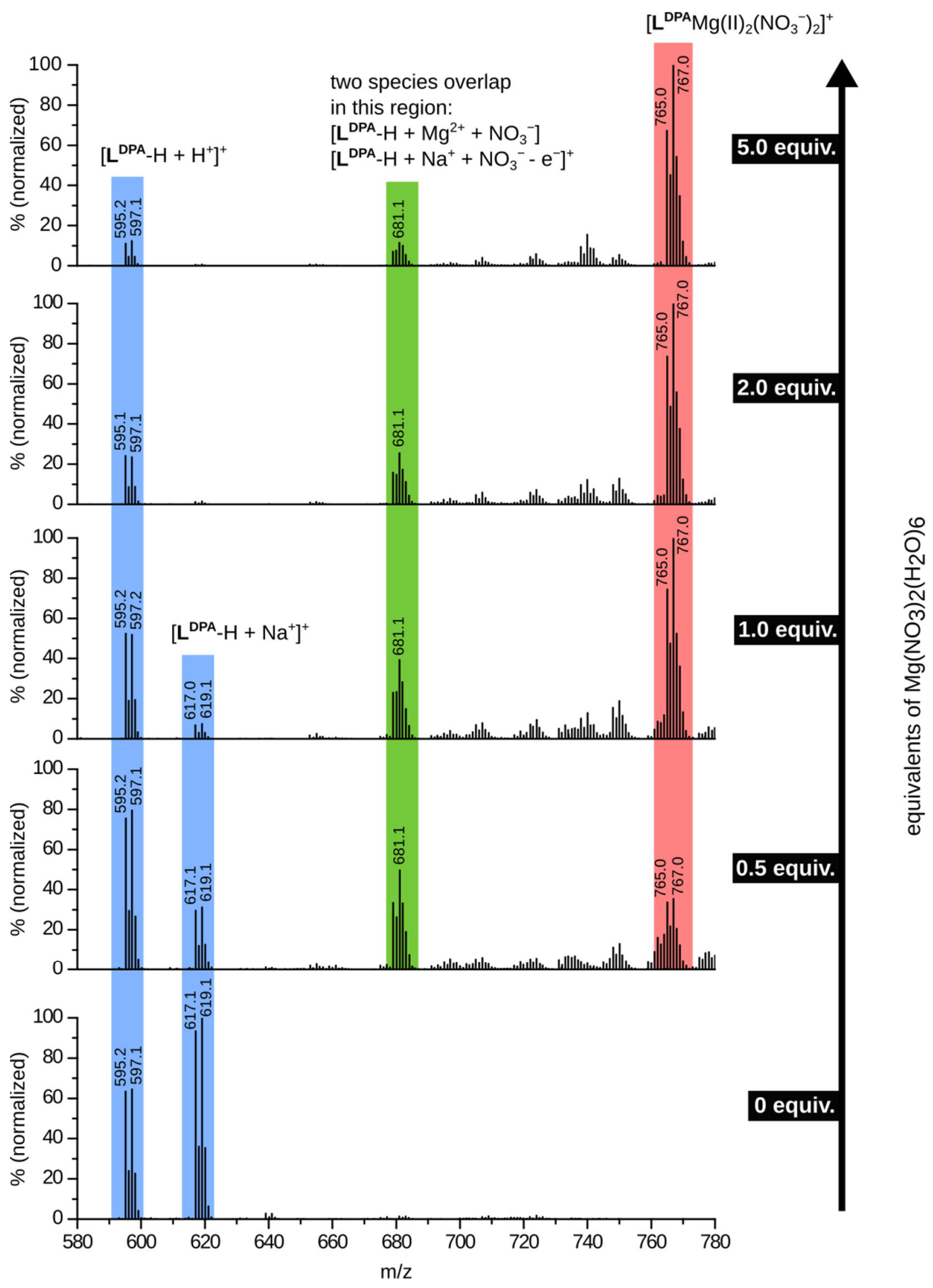

Figure S35: Low resolution ESI-MS of ligand $\mathbf{L}^{\mathbf{D P A}}-\mathrm{H}$ with different equivalents of magnesium salt. The monomeric magnesium complex overlaps with a similar sodium complex as pointed out by the calculated values and the observed isotope pattern. 


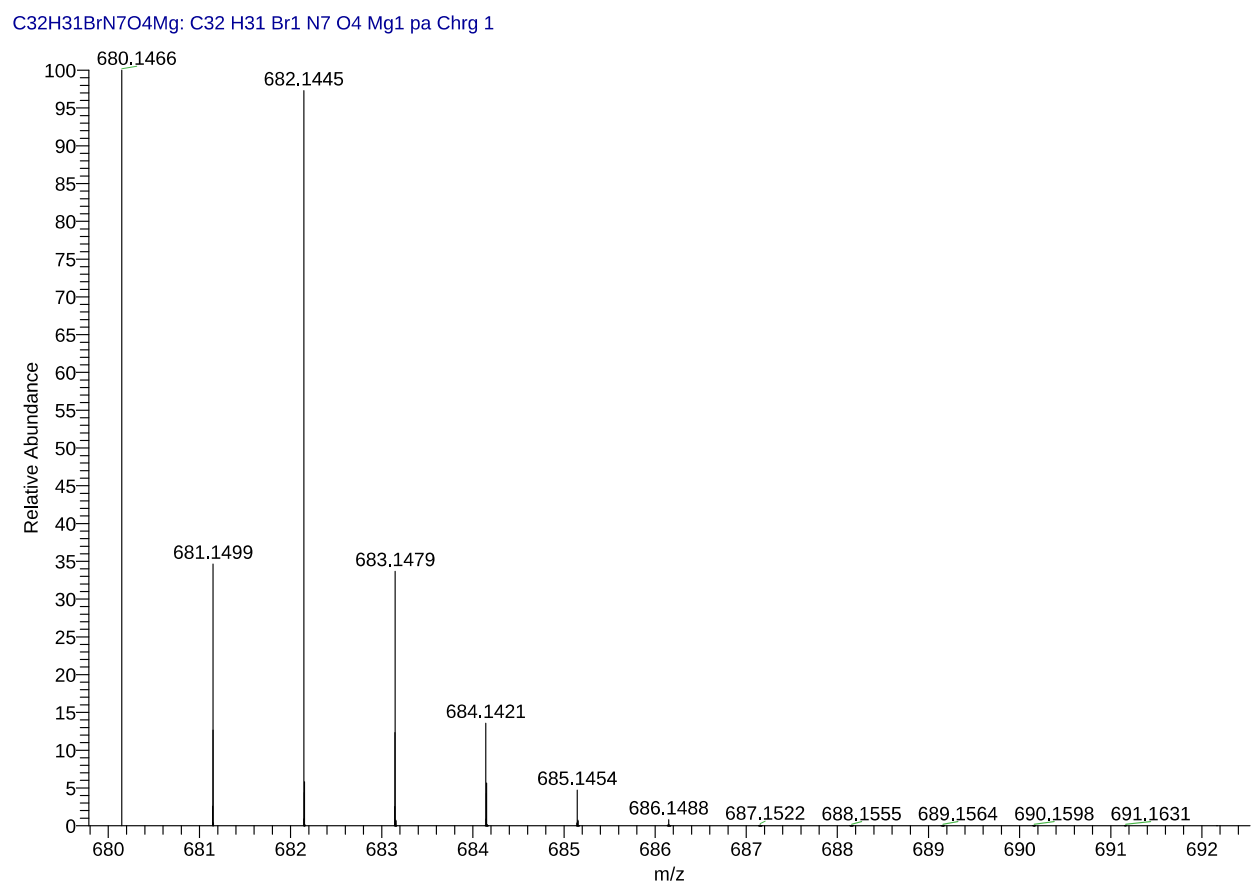

Figure S36: Calculated values for a pure 1:1 magnesium complex $\left[\mathbf{L}^{\mathbf{D P A}}-\mathrm{H}+\mathrm{Mg}^{2+}+\mathrm{NO}^{-}\right]$. Neither the pattern nor the values match the observed spectra. It is assumed that the 1:1 magnesium complex is not the only species in this particular $\mathrm{m} / \mathrm{z}$ region and overlap with another complex.

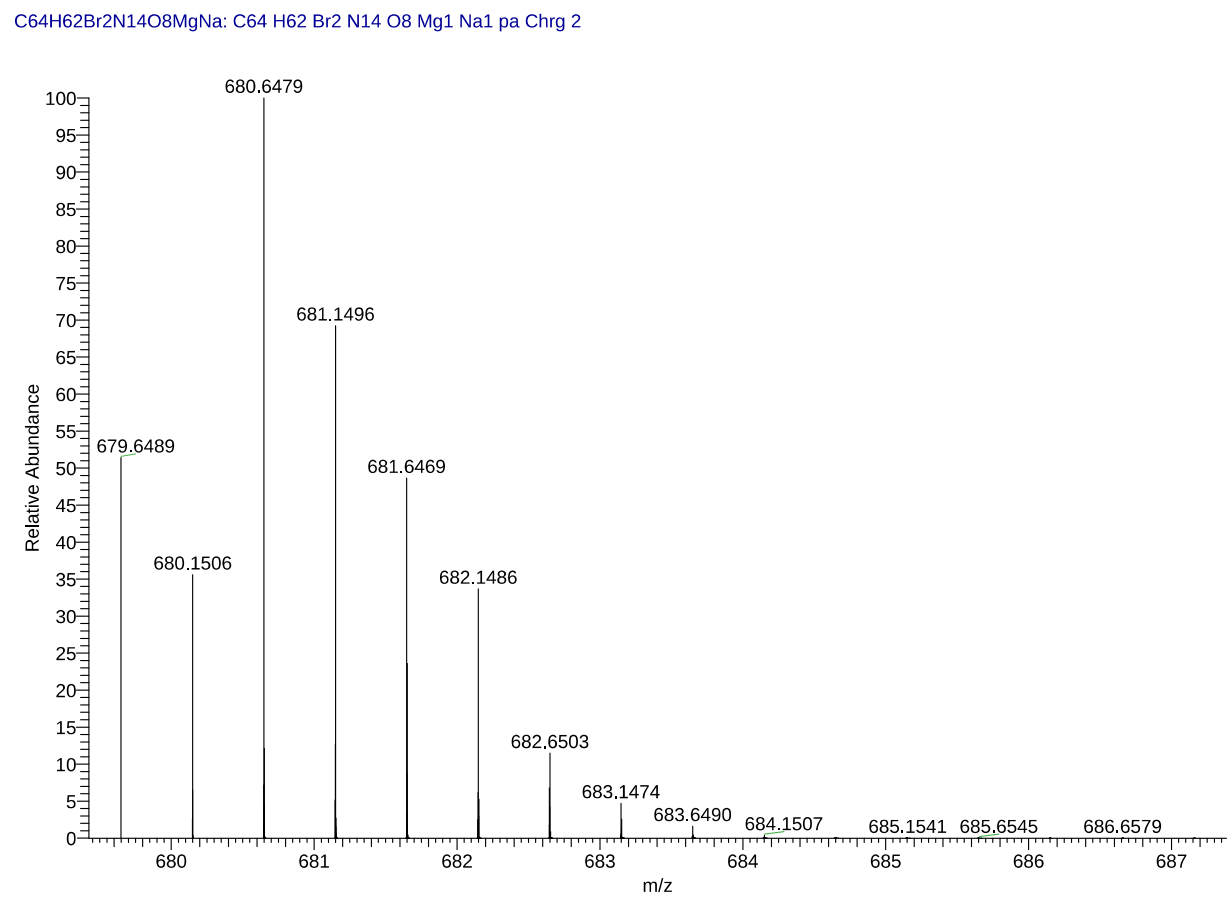

Figure S37: Calculated values for a 1:1 magnesium complex $\left[\mathbf{L}^{\mathbf{D P A}}-\mathrm{H}+\mathrm{Mg}^{2+}+\mathrm{NO}^{-}\right]^{+}$overlapping with a 1:1 sodium species $\left[\mathbf{L}^{\mathbf{D P A}}-\mathrm{H}+\mathrm{Na}^{+}+\mathrm{NO}^{-}-\mathrm{e}^{-}\right]^{+}$. The pattern and values are in accordance with the low resolution ESI-MS spectra. Thus, the formation of the 1:1 complex can be assumed even though it is not the only species in this $\mathrm{m} / \mathrm{z}$ region. 
High resolution ESI-MS spectra:

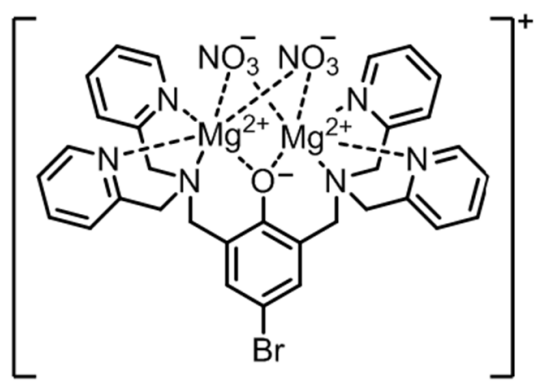

$\left[\mathrm{M}\left({ }^{79} \mathrm{Br}\right)\right]^{+}=765.1116 \mathrm{Da}$

$\left[\mathrm{M}\left({ }^{81} \mathrm{Br}\right)\right]^{+}=767.1104 \mathrm{Da}$

$\mathrm{NL}:$

4.50E6

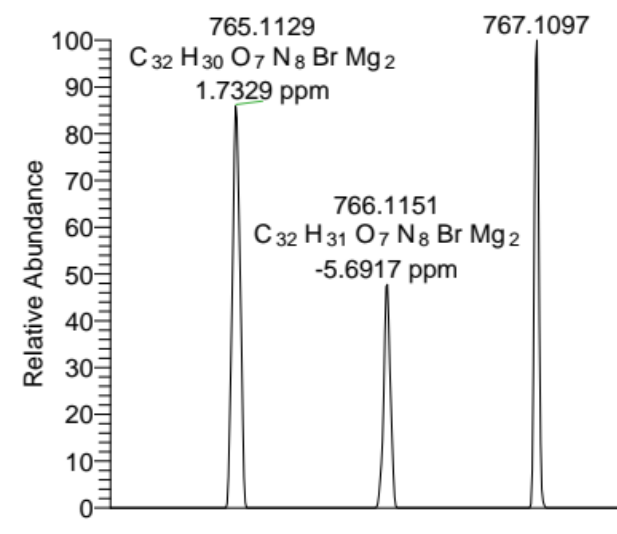

Observed Masses of Target Compound

dvc303A2\#29-45 RT:

0.22-0.37 AV: $17 \mathrm{~T}:$ FTMS +

p ESI Full ms

[100.00-2000.00]

NL:

3.09E5

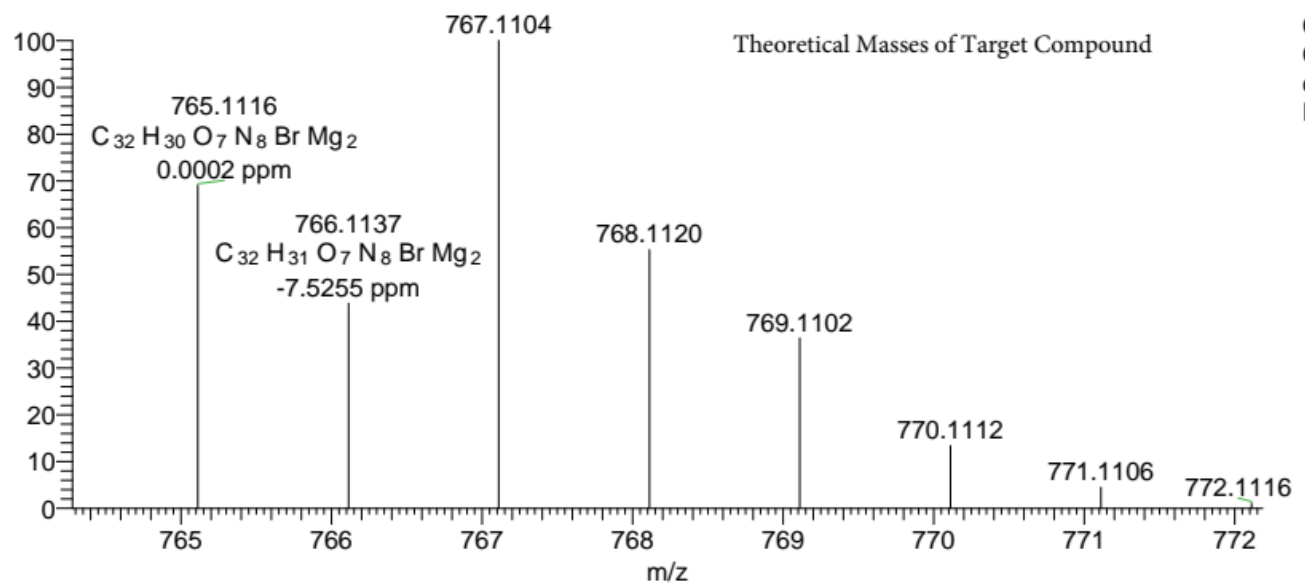

Figure S38: High resolution isotope pattern for the dinuclear magnesium bisdipicolylamine complex $\left[\mathbf{L}^{\mathbf{D P A}} \mathrm{Mg}_{2}\left(\mathrm{NO}_{3}\right)_{2}\right]^{+}$. Top: Measured values; Bottom: Calculated values. 

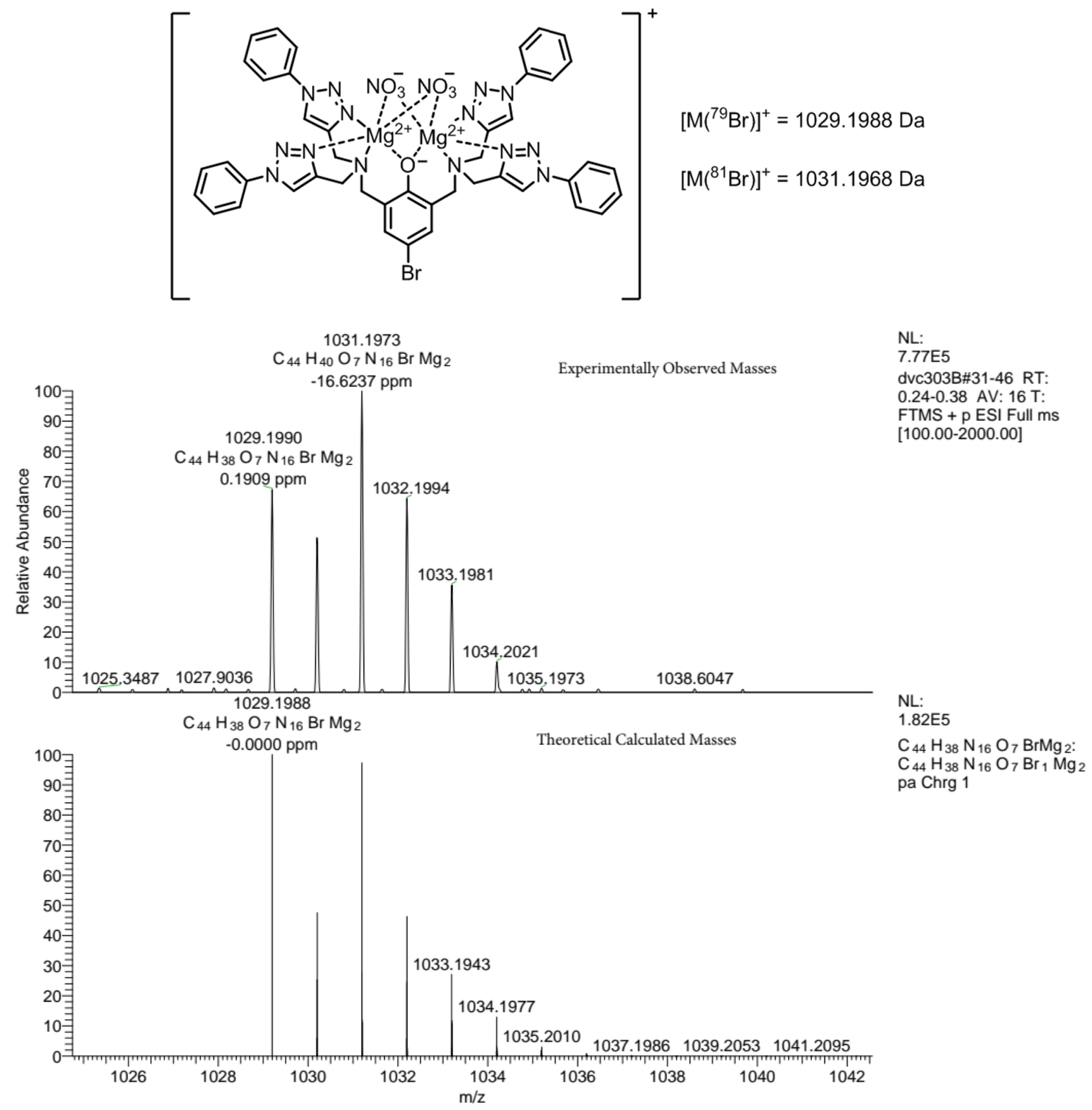

Figure S39: High resolution isotope pattern for the dinuclear magnesium triazole complex $\left[\mathbf{L}^{\text {triazole }} \mathrm{Mg}_{2}\left(\mathrm{NO}_{3}\right)_{2}\right]^{+}$. Top: Measured values; Bottom: Calculated values. 


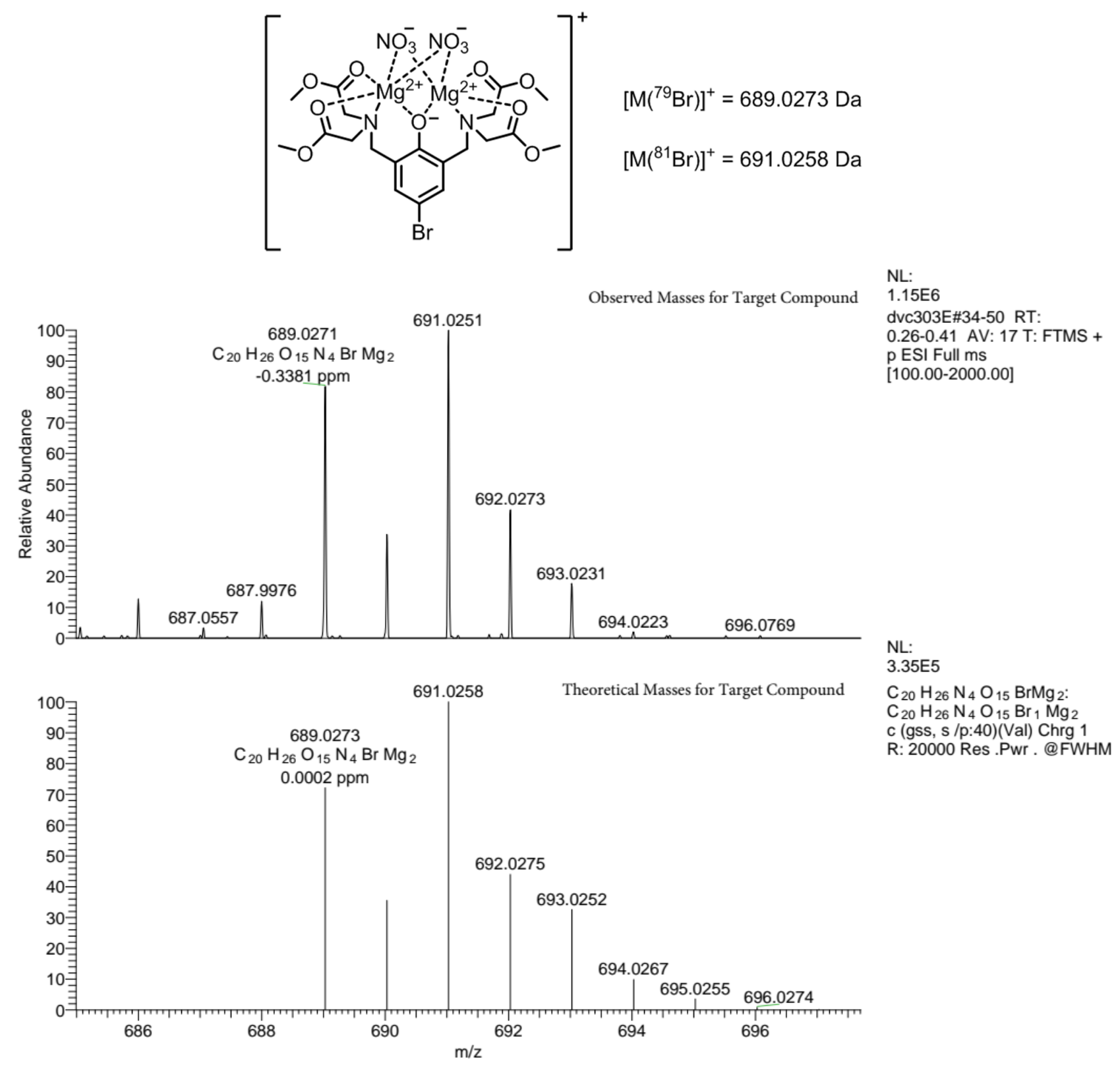

Figure S40: High resolution isotope pattern for the dinuclear magnesium methyl ester complex $\left[\mathbf{L}^{\mathrm{Me}} \mathrm{Mg}_{2}\left(\mathrm{NO}_{3}\right)_{2}\right]^{+}$. Top: Measured values; Bottom: Calculated values. 


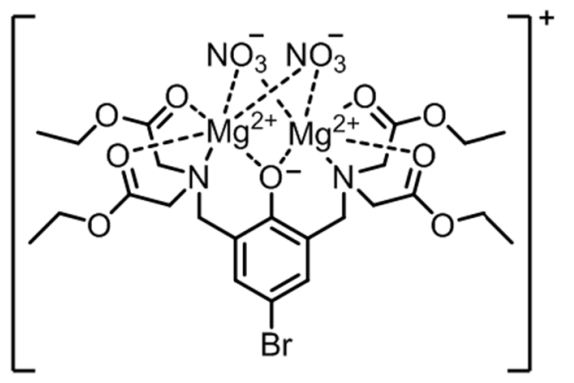

$\left[\mathrm{M}\left({ }^{79} \mathrm{Br}\right)\right]^{+}=745.0899 \mathrm{Da}$

$\left[\mathrm{M}\left({ }^{81} \mathrm{Br}\right)\right]^{+}=747.0885 \mathrm{Da}$

NL:

1.40E6

dvc303F\#32-46 RT:

0.25-0.38 AV: 15 T: FTMS + p ESI Full ms

$[100.00-2000.00]$
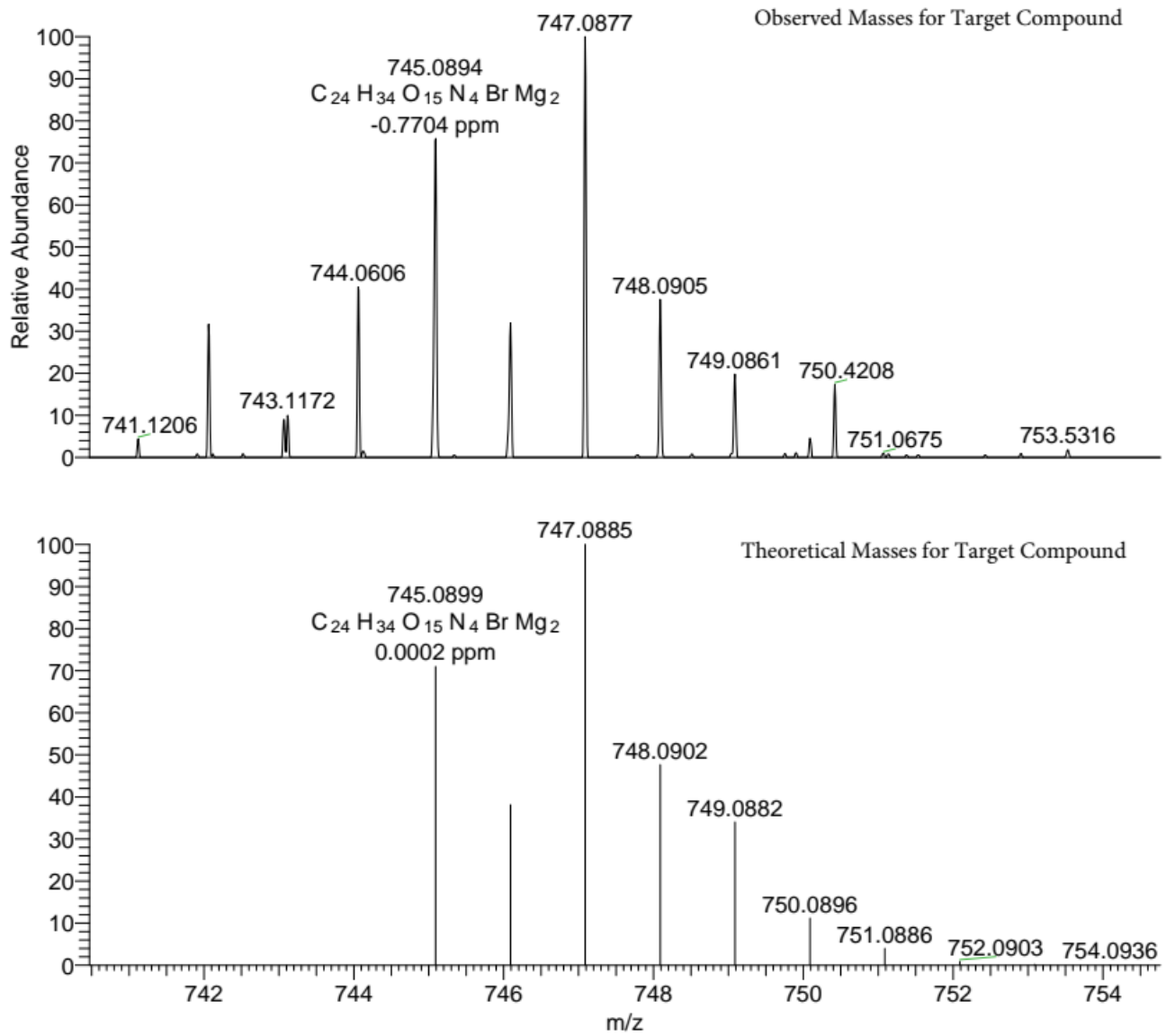

NL:

\subsection{E5}

$\mathrm{C}_{24} \mathrm{H}_{34} \mathrm{~N}_{4} \mathrm{O}_{15} \mathrm{BrMg}_{2}$ :

$\mathrm{C}_{24} \mathrm{H}_{34} \mathrm{~N}_{4} \mathrm{O}_{15} \mathrm{Br}_{1} \mathrm{Mg}_{2}$

c (gss, s /p:40)(Val) Chrg 1

R: 20000 Res.Pwr . @FWHM

Figure S41: High resolution isotope pattern for the dinuclear magnesium ethyl ester complex $\left[\mathbf{L}^{\mathrm{Et}} \mathrm{Mg}_{2}\left(\mathrm{NO}_{3}\right)_{2}\right]^{+}$. Top: Measured values; Bottom: Calculated values. 


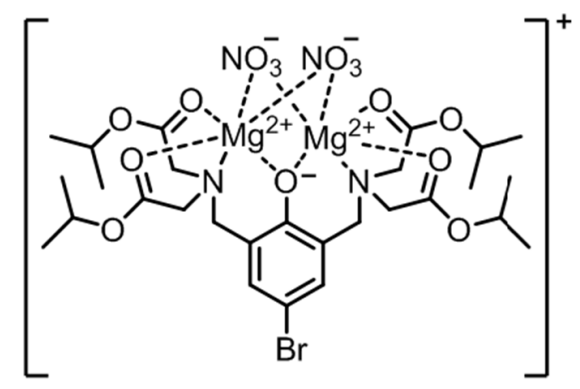

$$
\begin{aligned}
& {\left[\mathrm{M}\left({ }^{79} \mathrm{Br}\right)\right]^{+}=801.1525 \mathrm{Da}} \\
& {\left[\mathrm{M}\left({ }^{81} \mathrm{Br}\right)\right]^{+}=803.1512 \mathrm{Da}}
\end{aligned}
$$

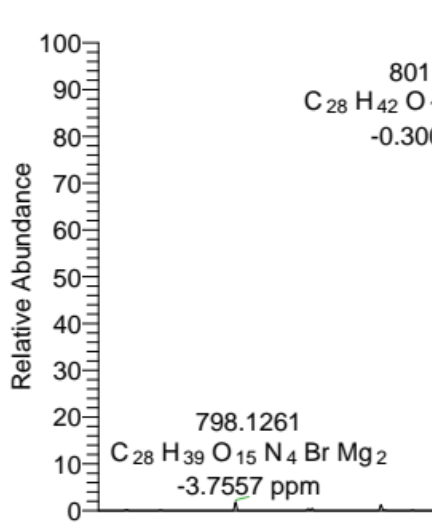

803.1506

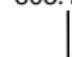
$\mathrm{O}_{15} \mathrm{~N}_{4} \mathrm{Br} \mathrm{Mg}$ $3007 \mathrm{ppm}$

Observed Masses of target compound
$\mathrm{NL}:$

7.31E6

dvc303G\#30-46 RT:

0.23-0.39 AV: 17 T: FTMS + p ESI Full ms

100.00-2000.00]

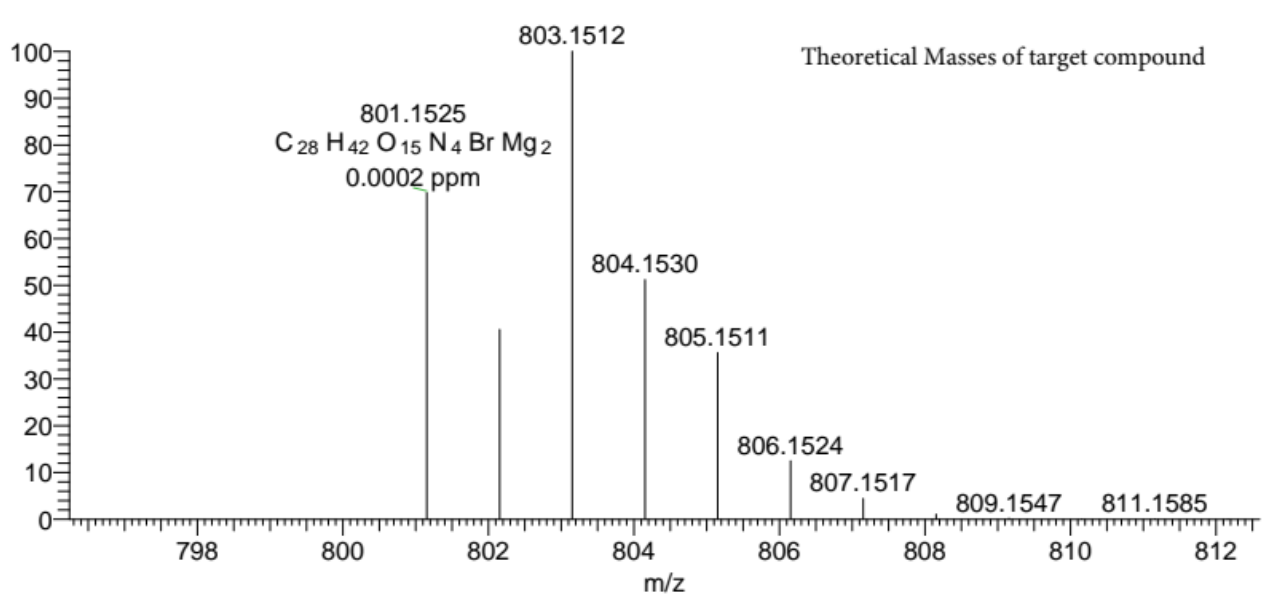

NL:

\subsection{E5}

$\mathrm{C}_{28} \mathrm{H}_{42} \mathrm{~N}_{4} \mathrm{O}_{15} \mathrm{BrMg}_{2}$ :

$\mathrm{C}_{28} \mathrm{H}_{42} \mathrm{~N}_{4} \mathrm{O}_{15} \mathrm{Br}_{1} \mathrm{Mg}_{2}$

c (gss, s /p:40)(Val) Chrg 1

R: 20000 Res.Pwr . @FWHM

Figure S42: High resolution isotope pattern for the dinuclear magnesium isopropyl ester complex $\left[\mathbf{L}^{\text {iPr }} \mathrm{Mg}_{2}\left(\mathrm{NO}_{3}\right)_{2}\right]^{+}$. Top: Measured values; Bottom: Calculated values. 

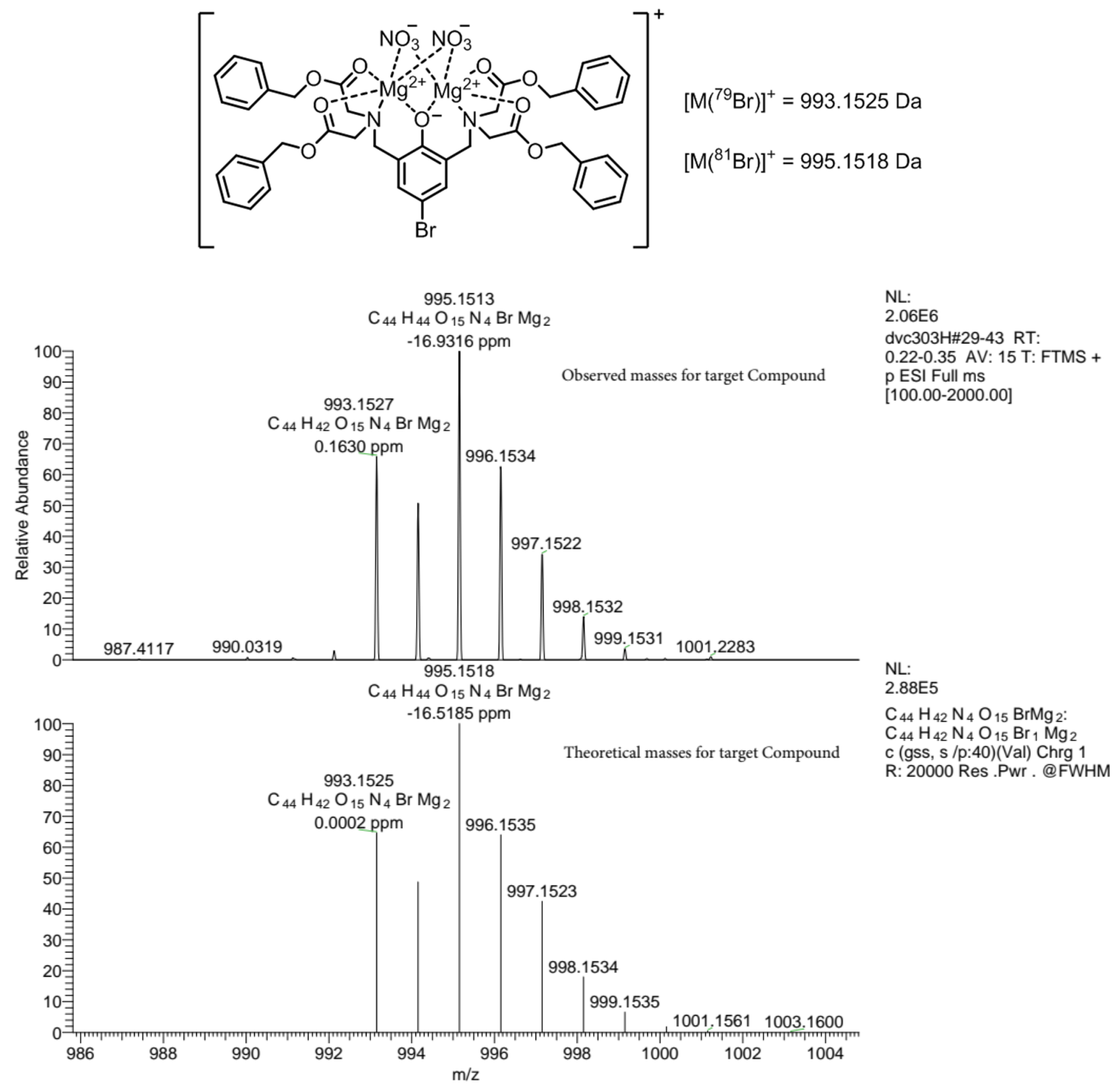

Figure S43: High resolution isotope pattern for the dinuclear magnesium benzyl ester complex $\left[\mathbf{L}^{\mathbf{B z}} \mathrm{Mg}_{2}\left(\mathrm{NO}_{3}\right)_{2}\right]^{+}$. Top: Measured values; Bottom: Calculated values. 
5. NMR Spectra of Compounds 


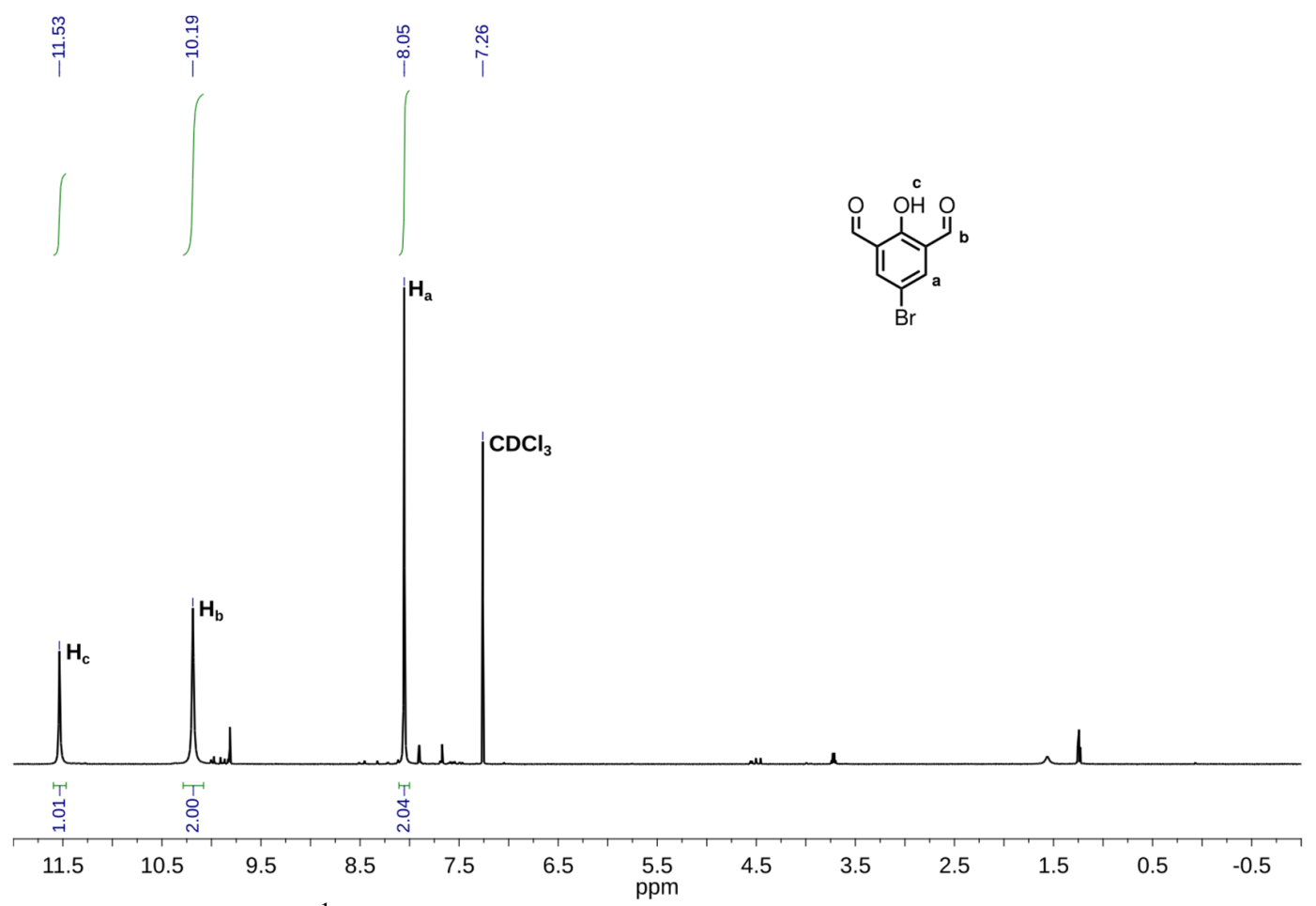

Figure S44: ${ }^{1} \mathrm{H}$ NMR spectrum of dialdehyde 2 after recrystallization.

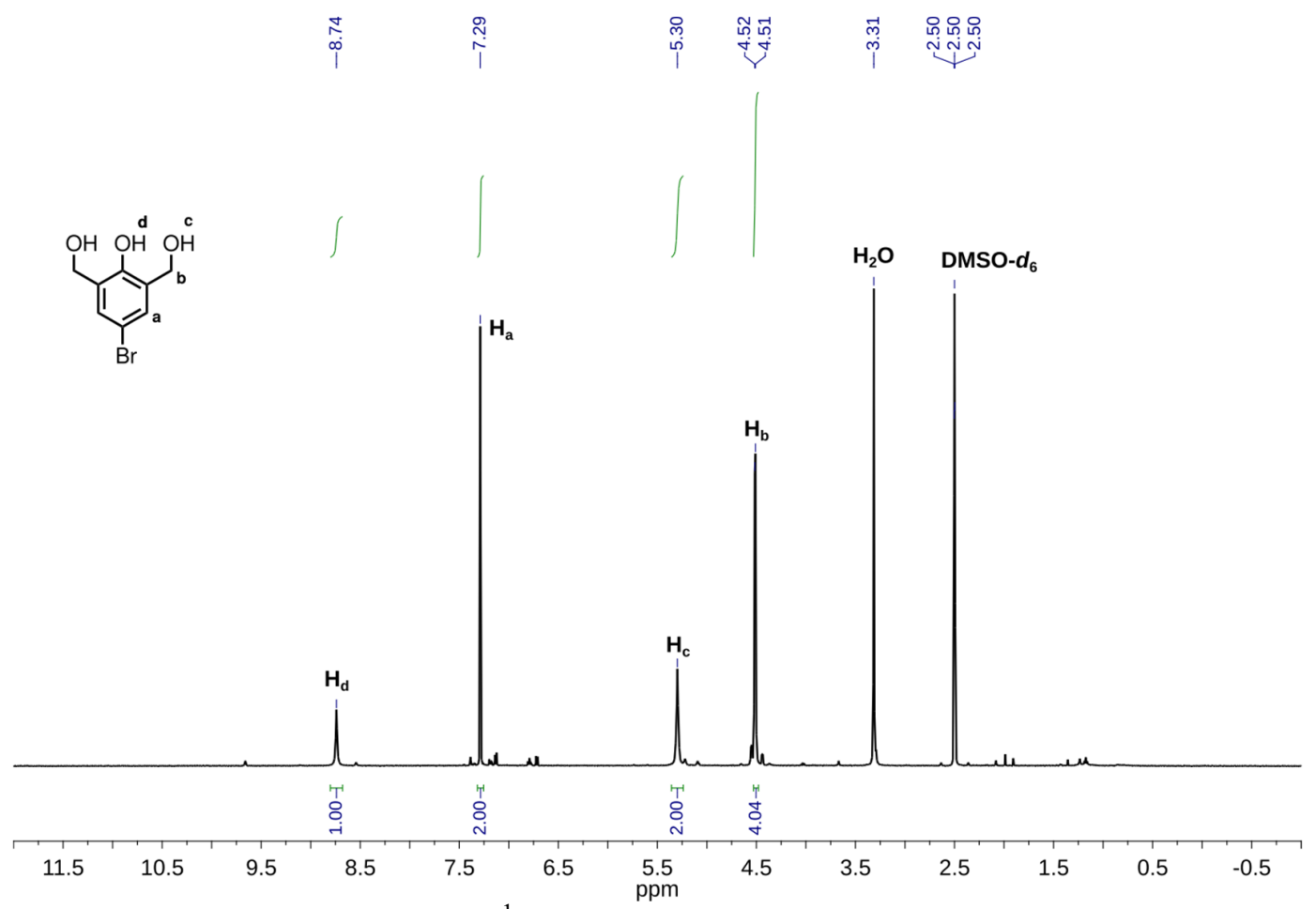

Figure S45: ${ }^{1} \mathrm{H}$ NMR spectrum of trialcohol 3 . 


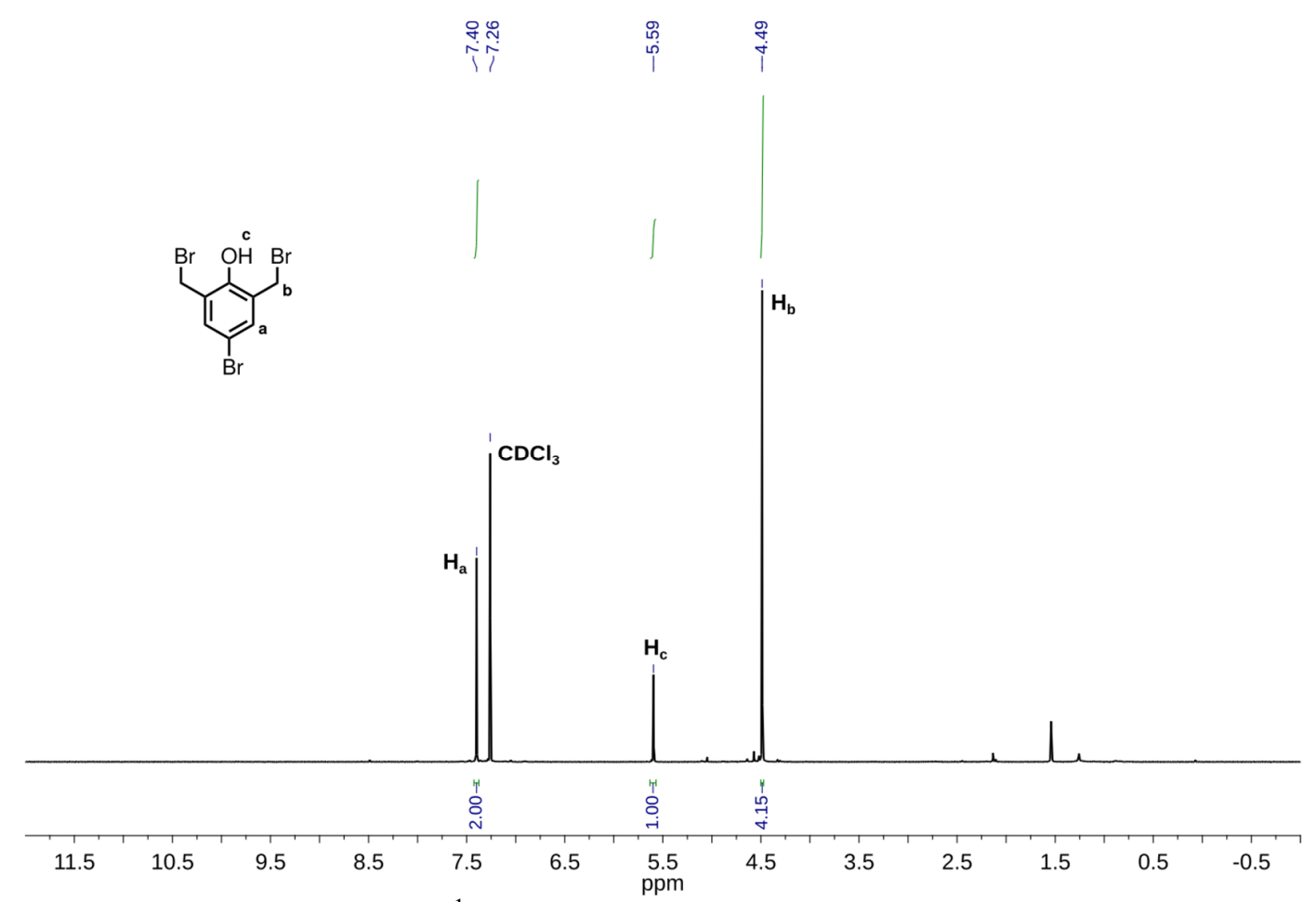

Figure S46: ${ }^{1} \mathrm{H}$ NMR spectrum of ligand precursor 4 .

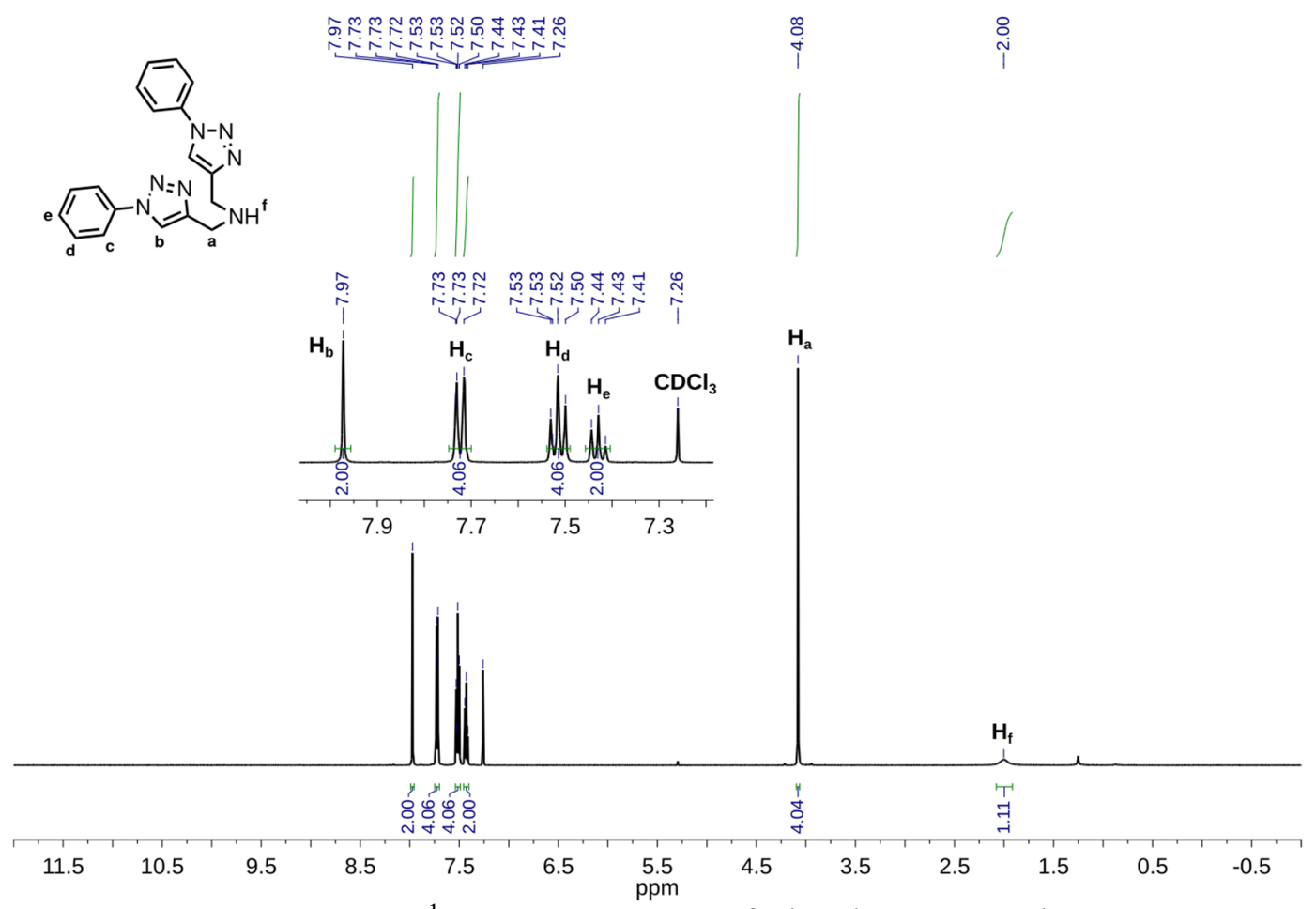

Figure S47: ${ }^{1} \mathrm{H}$ NMR spectrum of triazole compound 5 . 


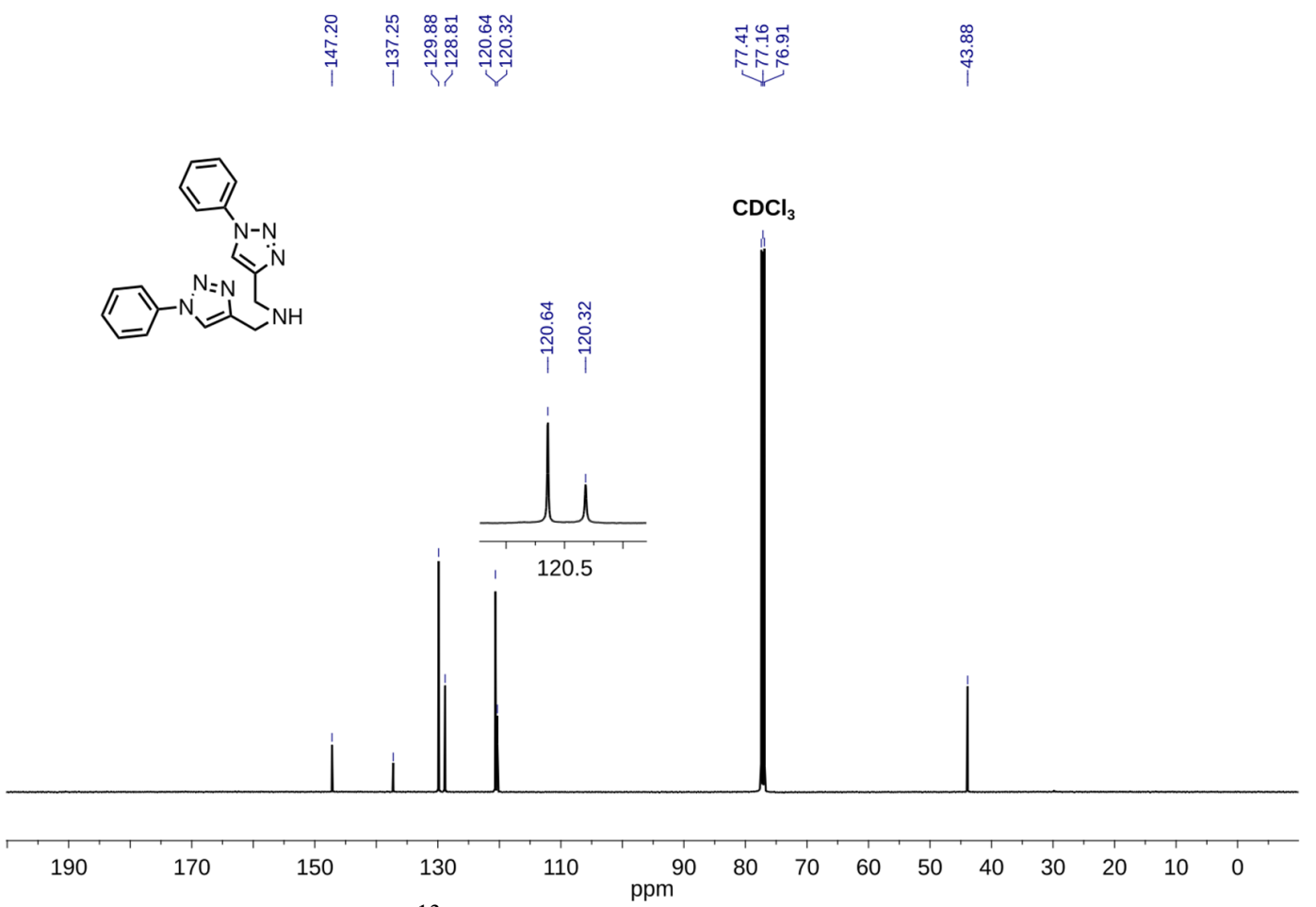

Figure S48: ${ }^{13} \mathrm{C}$ NMR spectrum of triazole compound 5.

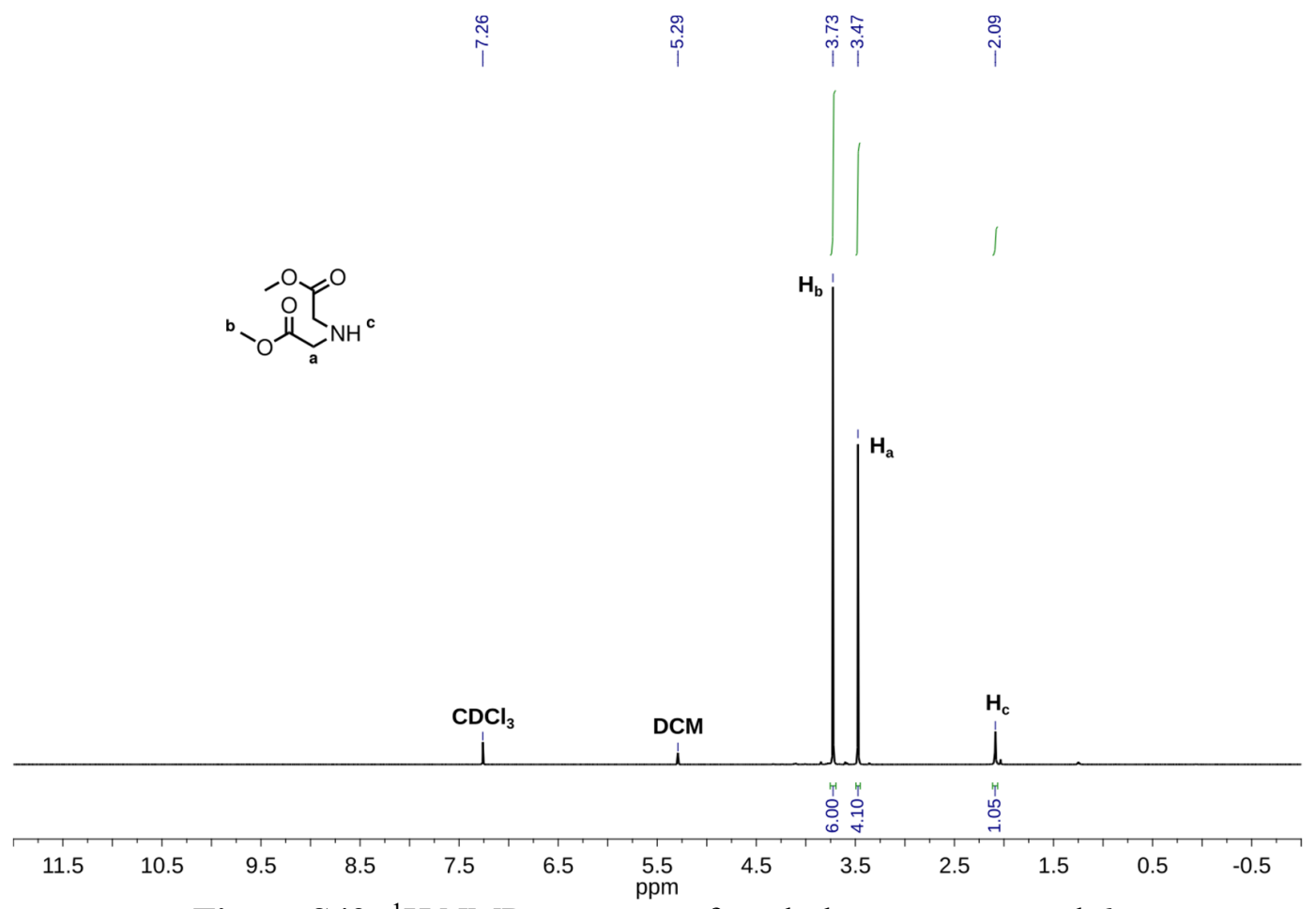

Figure S49: ${ }^{1} \mathrm{H}$ NMR spectrum of methyl ester compound 6. 


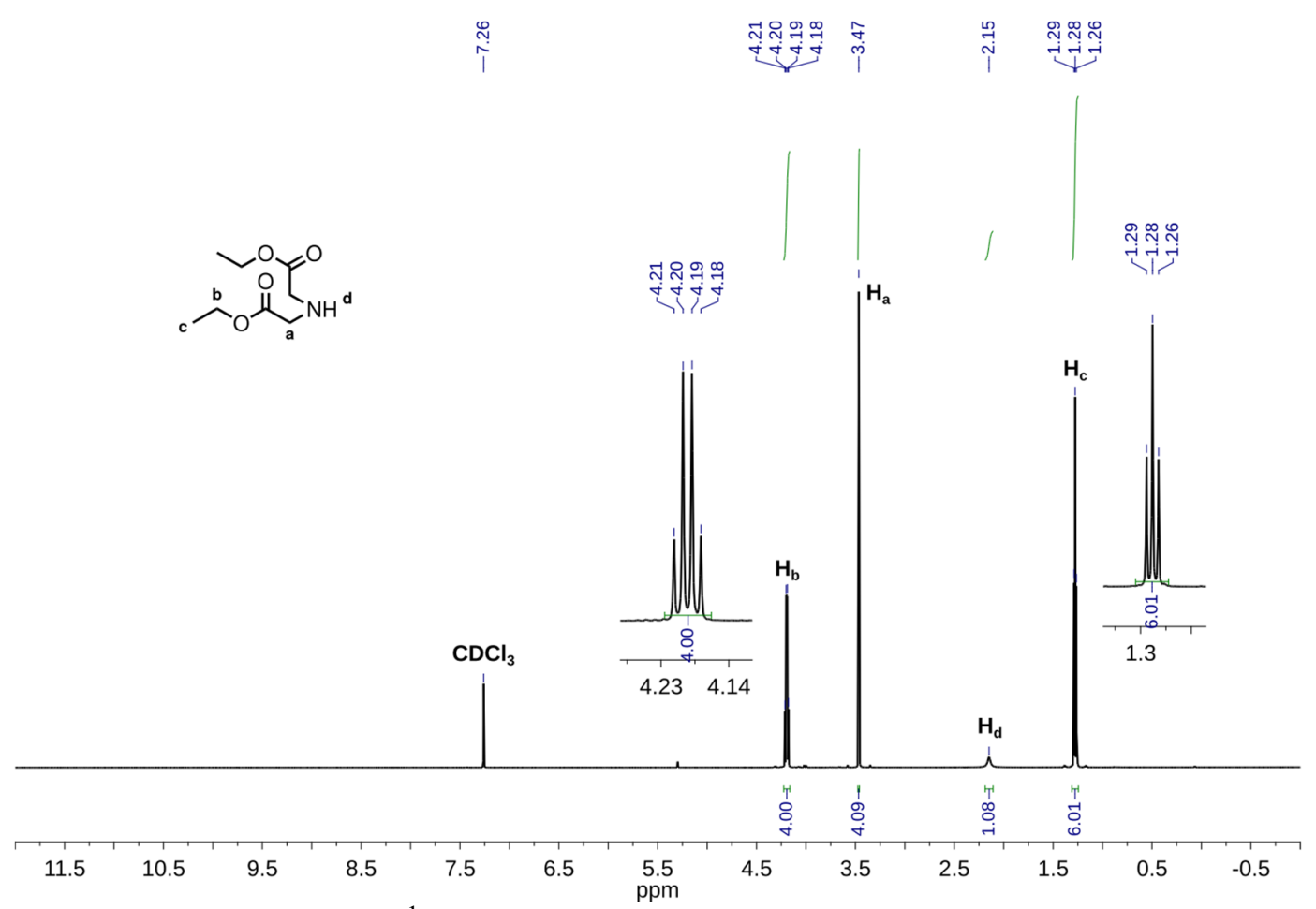

Figure S50: ${ }^{1} \mathrm{H}$ NMR spectrum of ethyl ester compound 7.

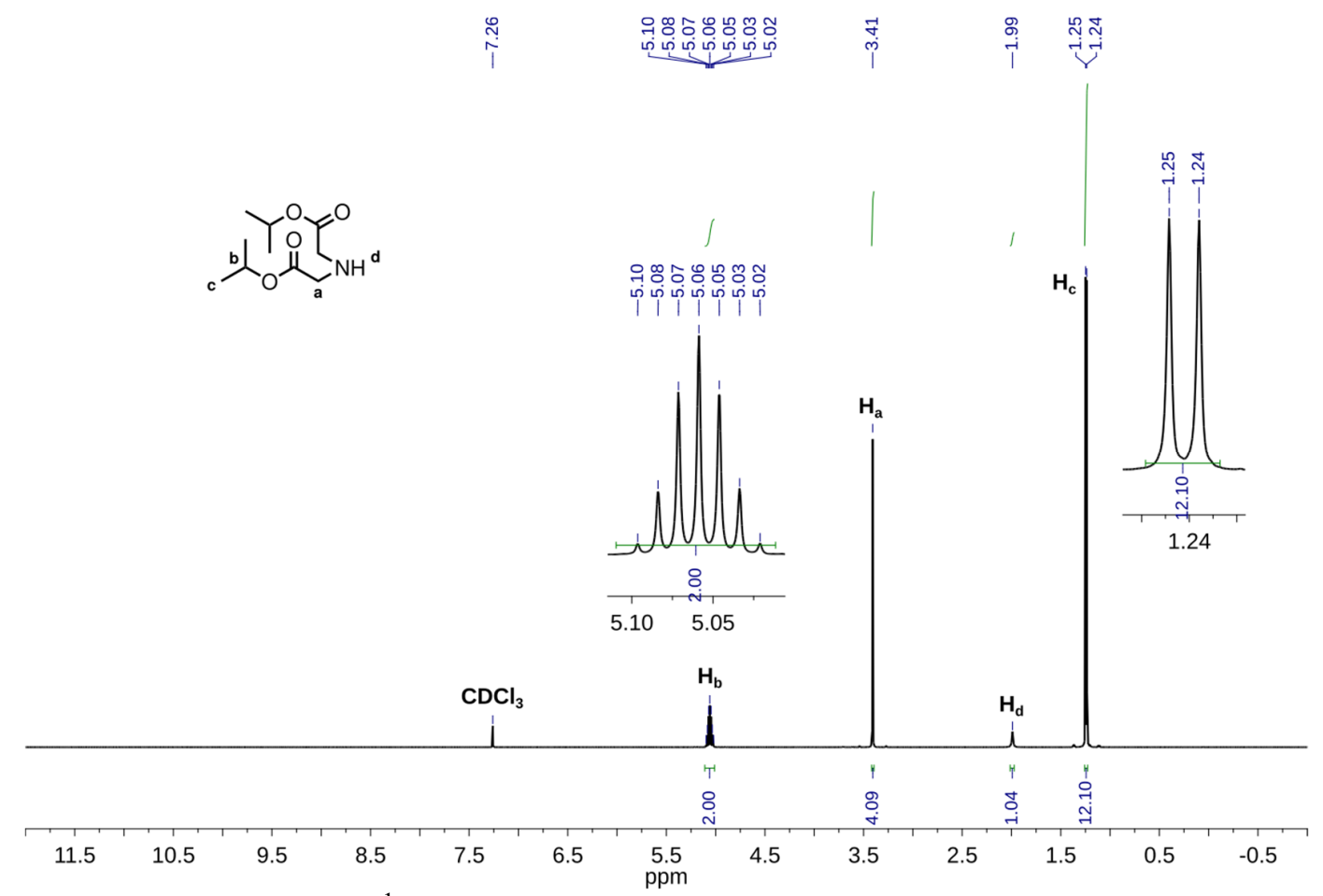

Figure S51: ${ }^{1} \mathrm{H}$ NMR spectrum of isopropyl ester compound 8 . 


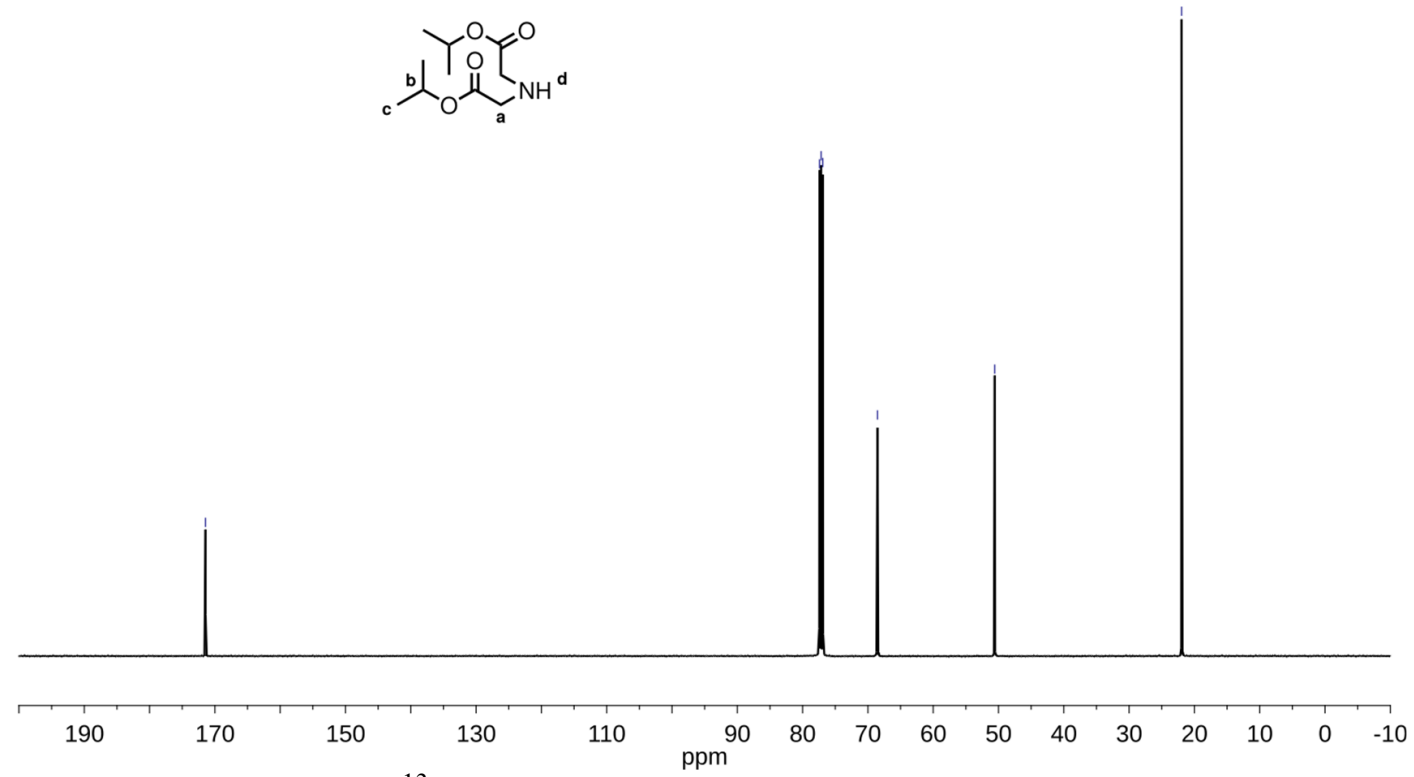

Figure S52: ${ }^{13} \mathrm{C}$ NMR spectrum of isopropyl ester compound 8 .

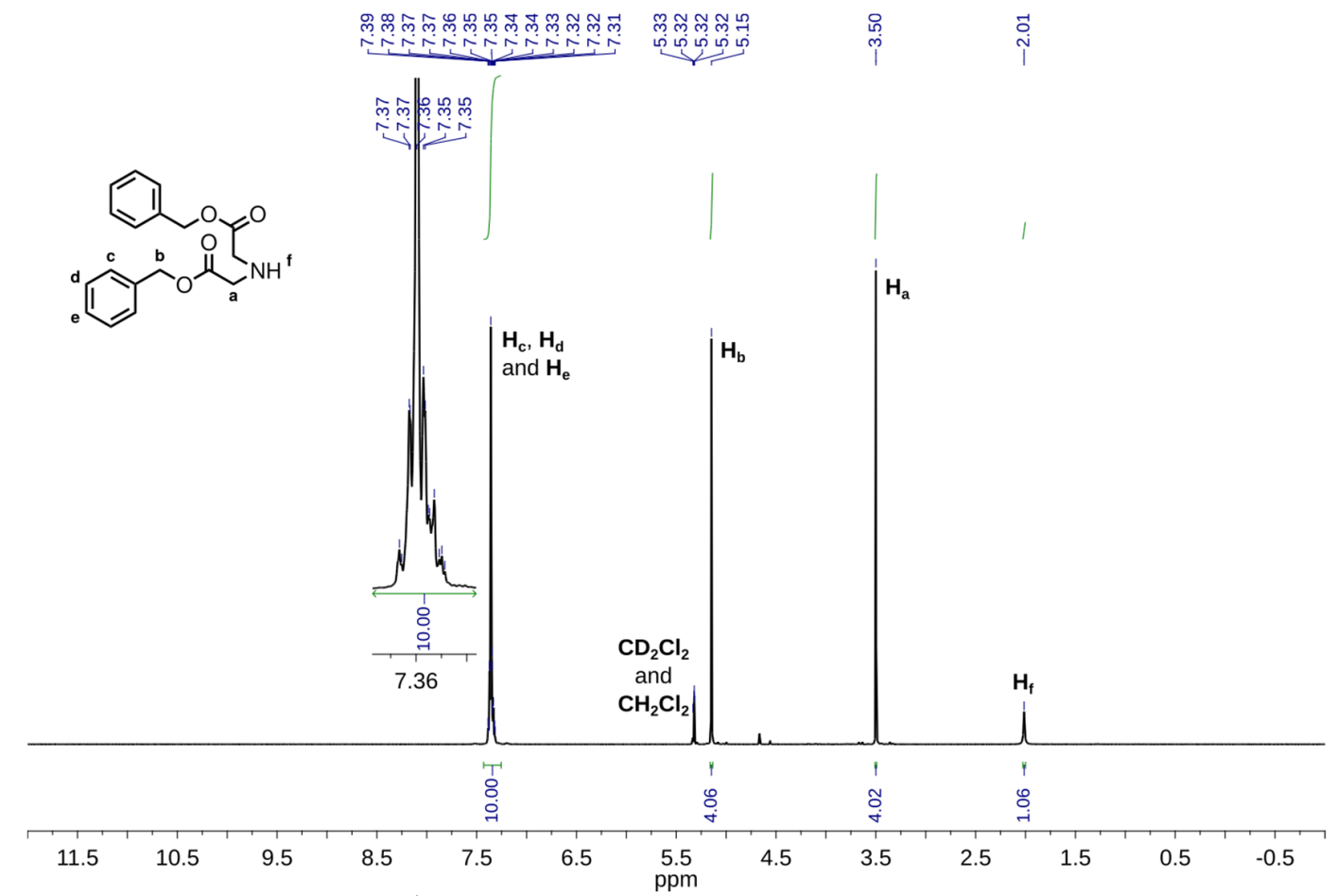

Figure S53: ${ }^{1} \mathrm{H}$ NMR spectrum of benzyl ester compound 9. 


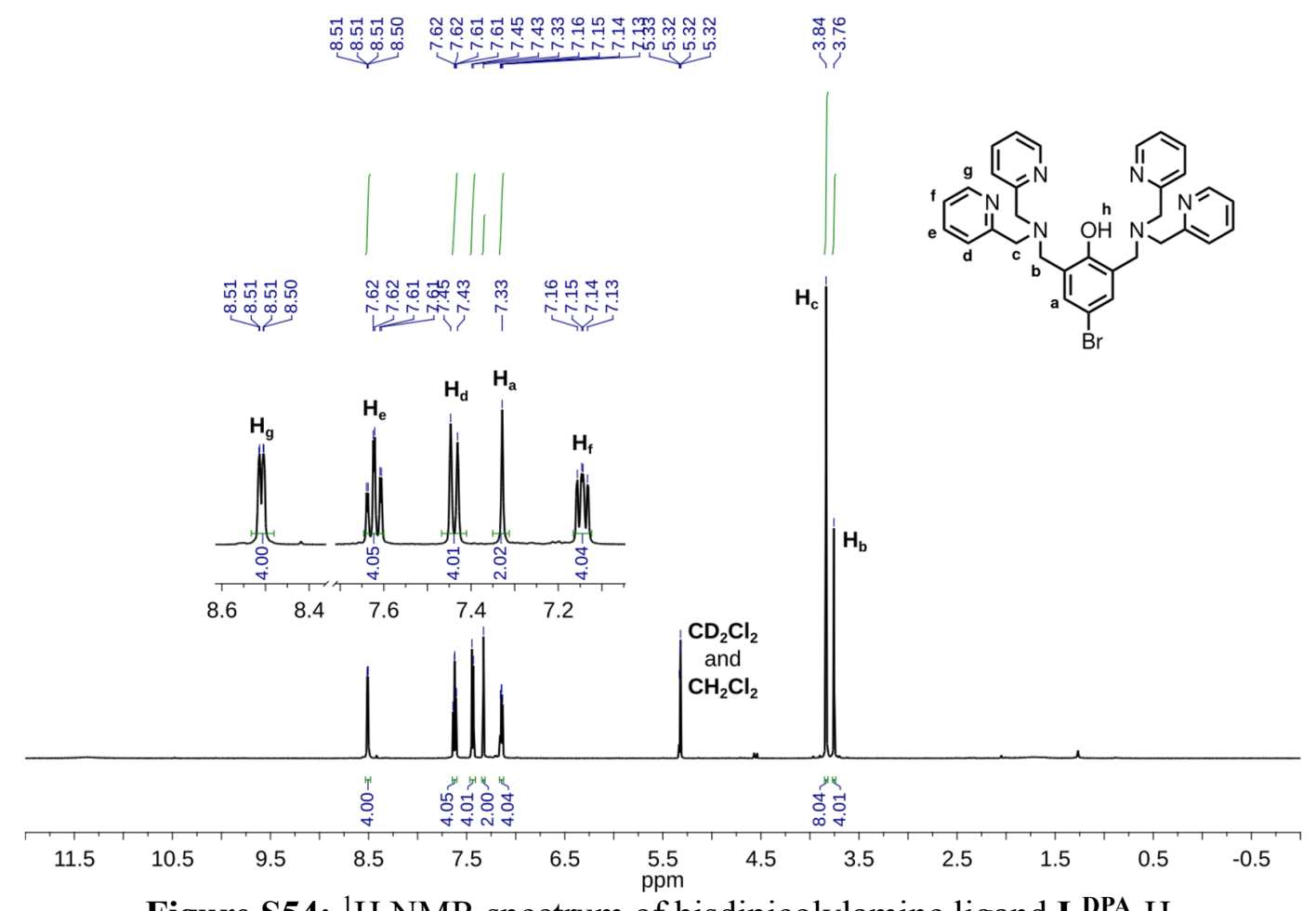

Figure S54: ${ }^{1} \mathrm{H}$ NMR spectrum of bisdipicolylamine ligand $\mathbf{L}^{\mathbf{D P A}}-\mathrm{H}$.

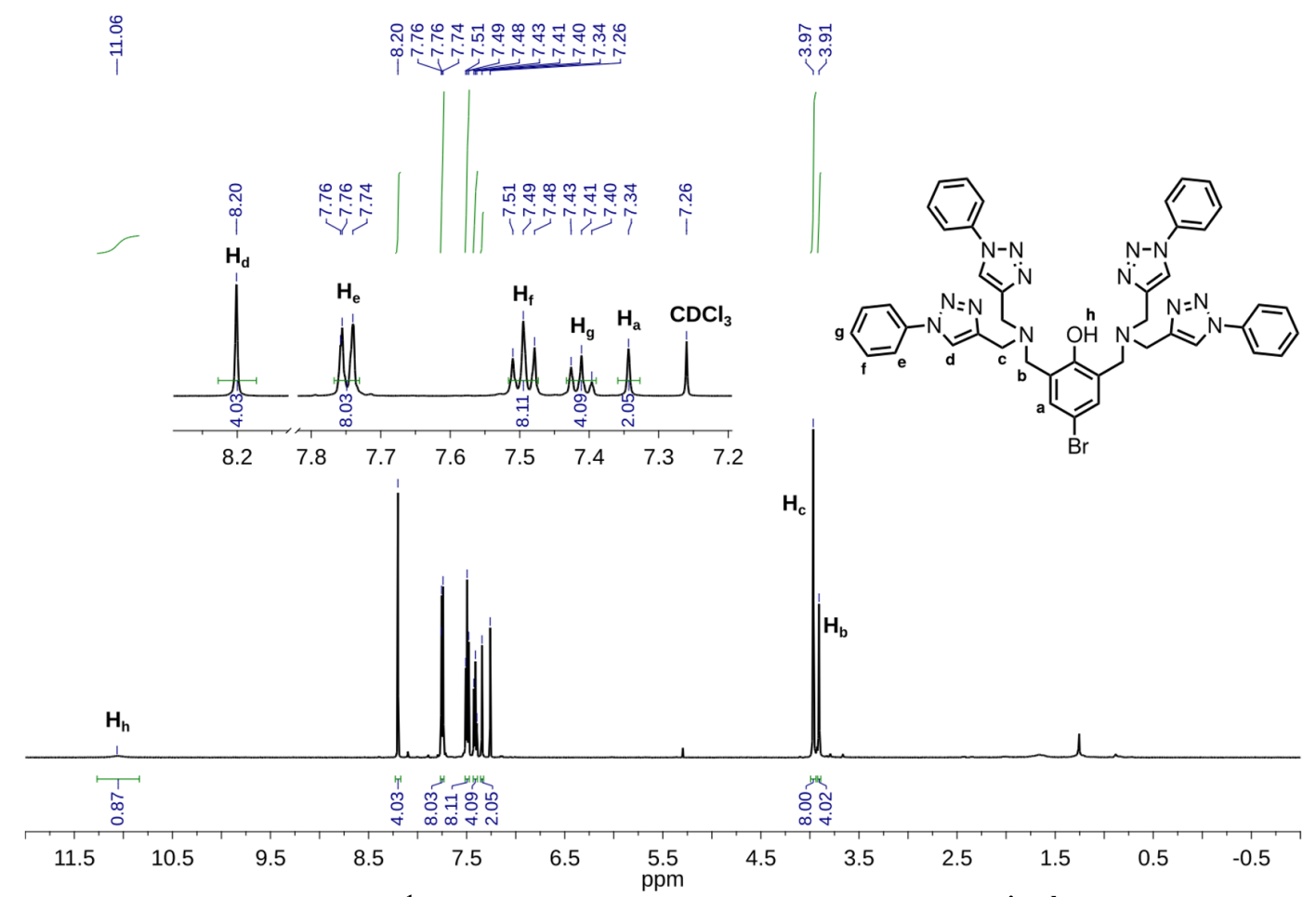

Figure S55: ${ }^{1} \mathrm{H}$ NMR spectrum of triazole ligand $\mathbf{L}^{\text {triazole }}-\mathrm{H}$. 


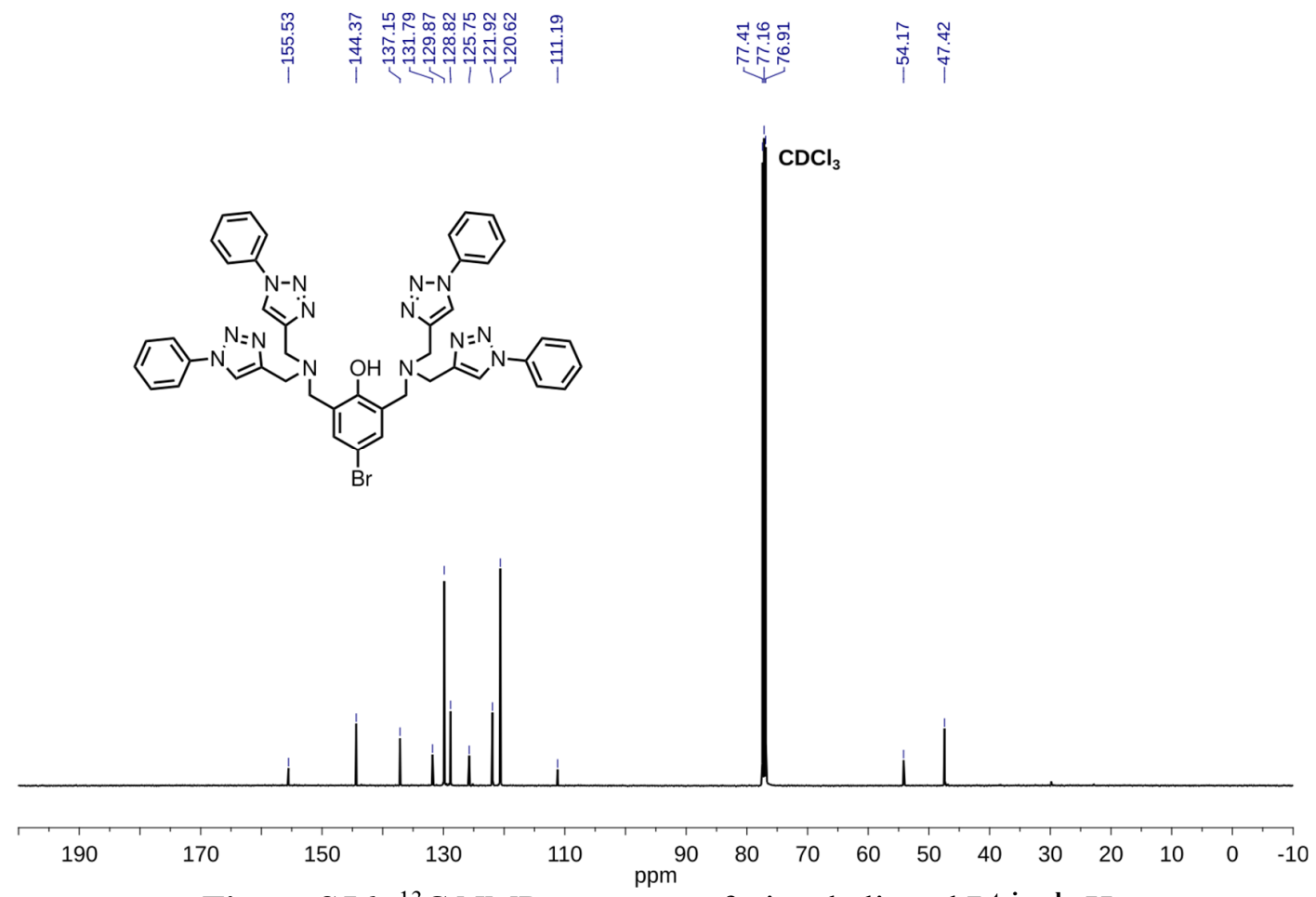

Figure S56: ${ }^{13} \mathrm{C}$ NMR spectrum of triazole ligand $\mathbf{L}^{\text {triazole }}-\mathrm{H}$.

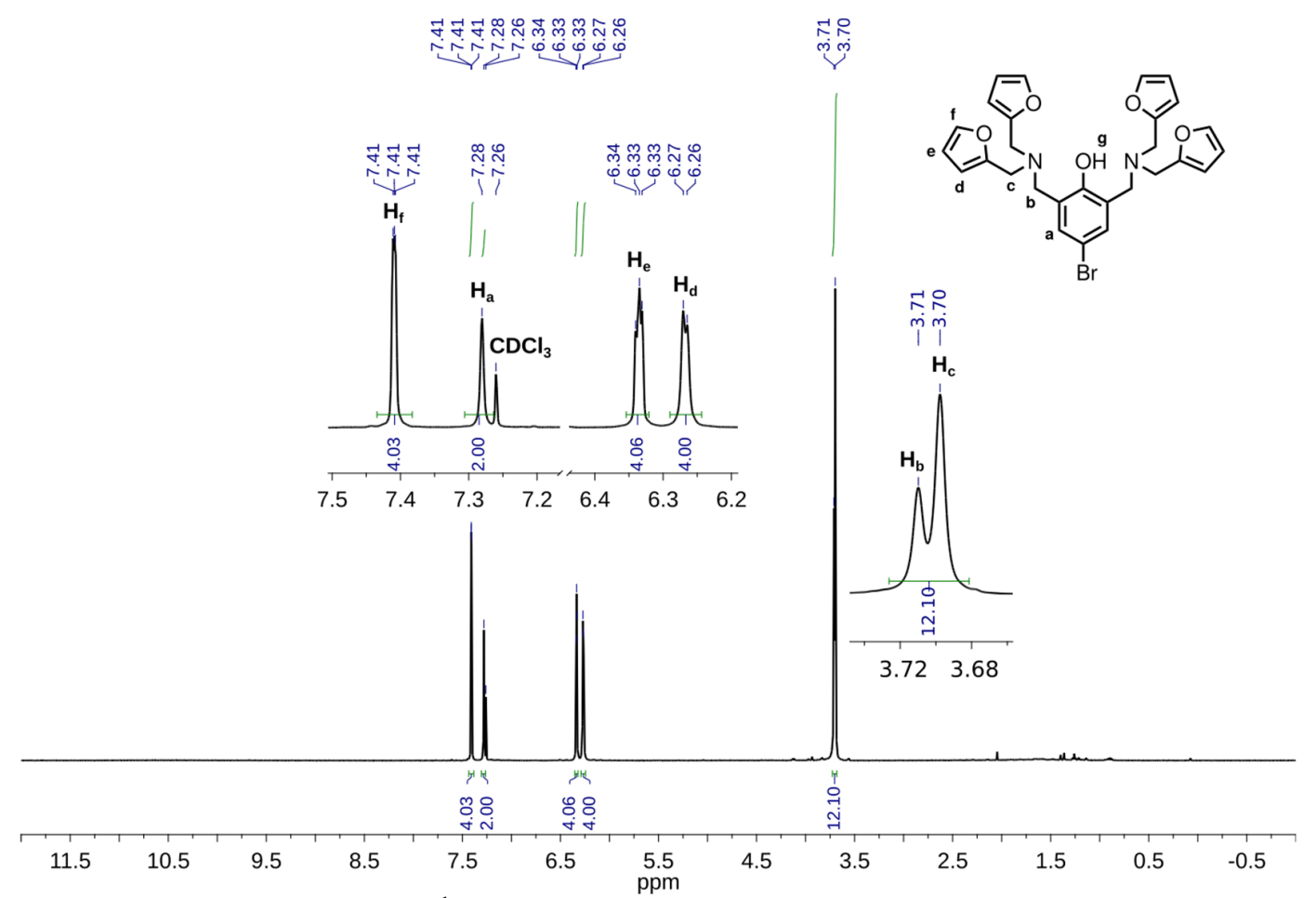

Figure S57: ${ }^{1} \mathrm{H}$ NMR spectrum of furane ligand $\mathbf{L}^{\text {furane }}-\mathrm{H}$. 


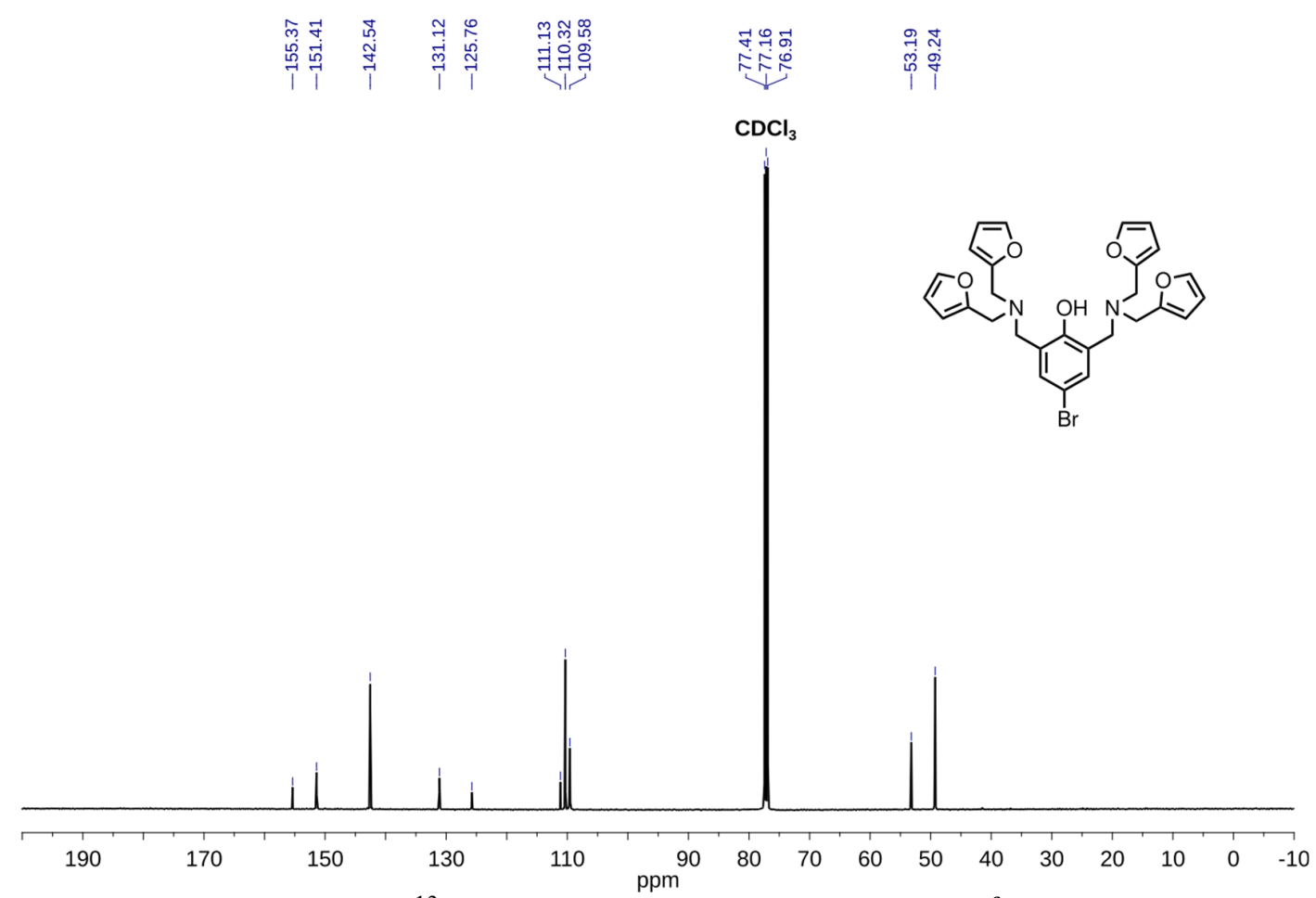

Figure S58: ${ }^{13} \mathrm{C}$ NMR spectrum of furane ligand $\mathbf{L}^{\text {furane }}-\mathrm{H}$.

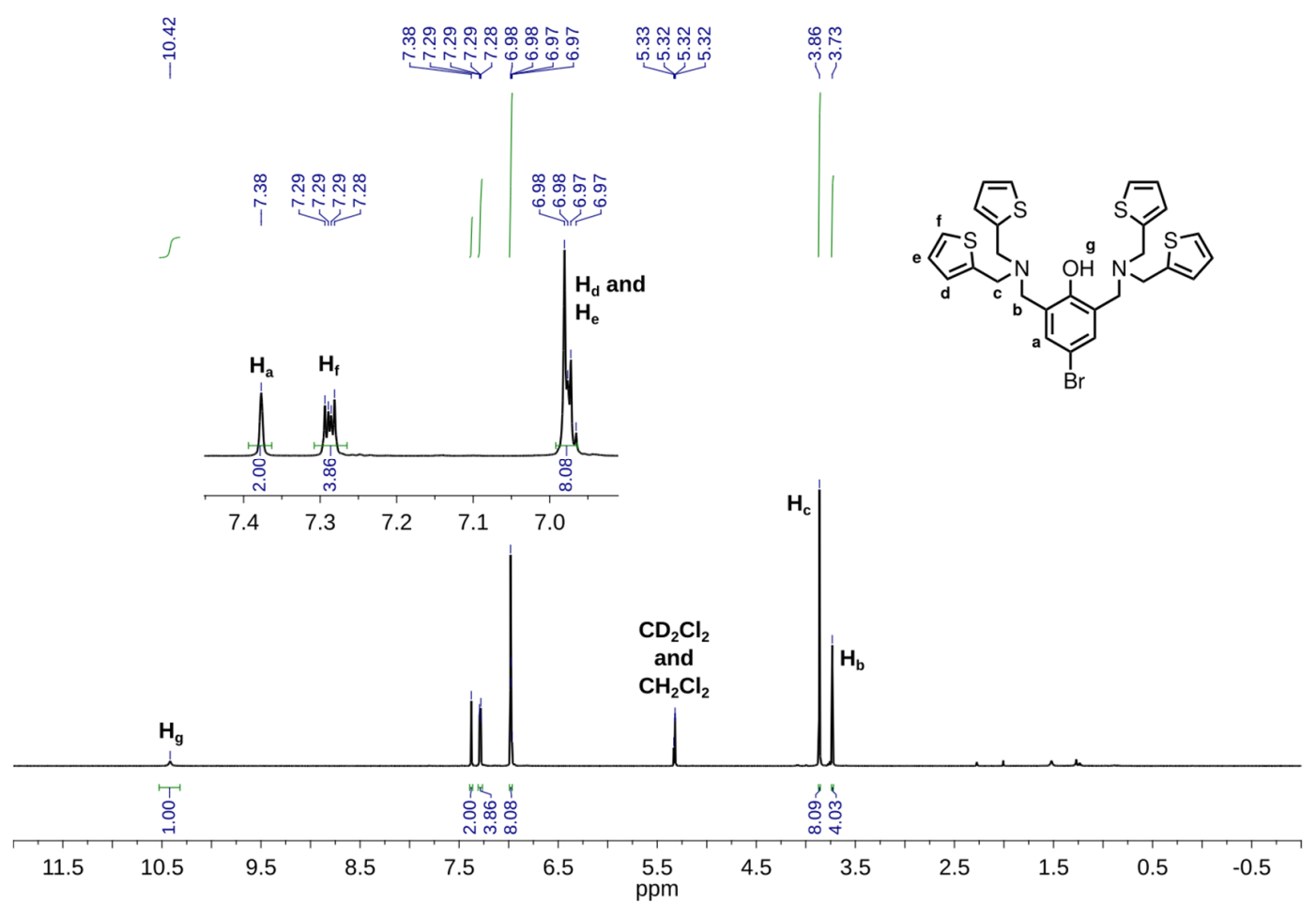

Figure S59: ${ }^{1} \mathrm{H}$ NMR spectrum of thiophen ligand $\mathbf{L}^{\text {thiophen }}-\mathrm{H}$. 


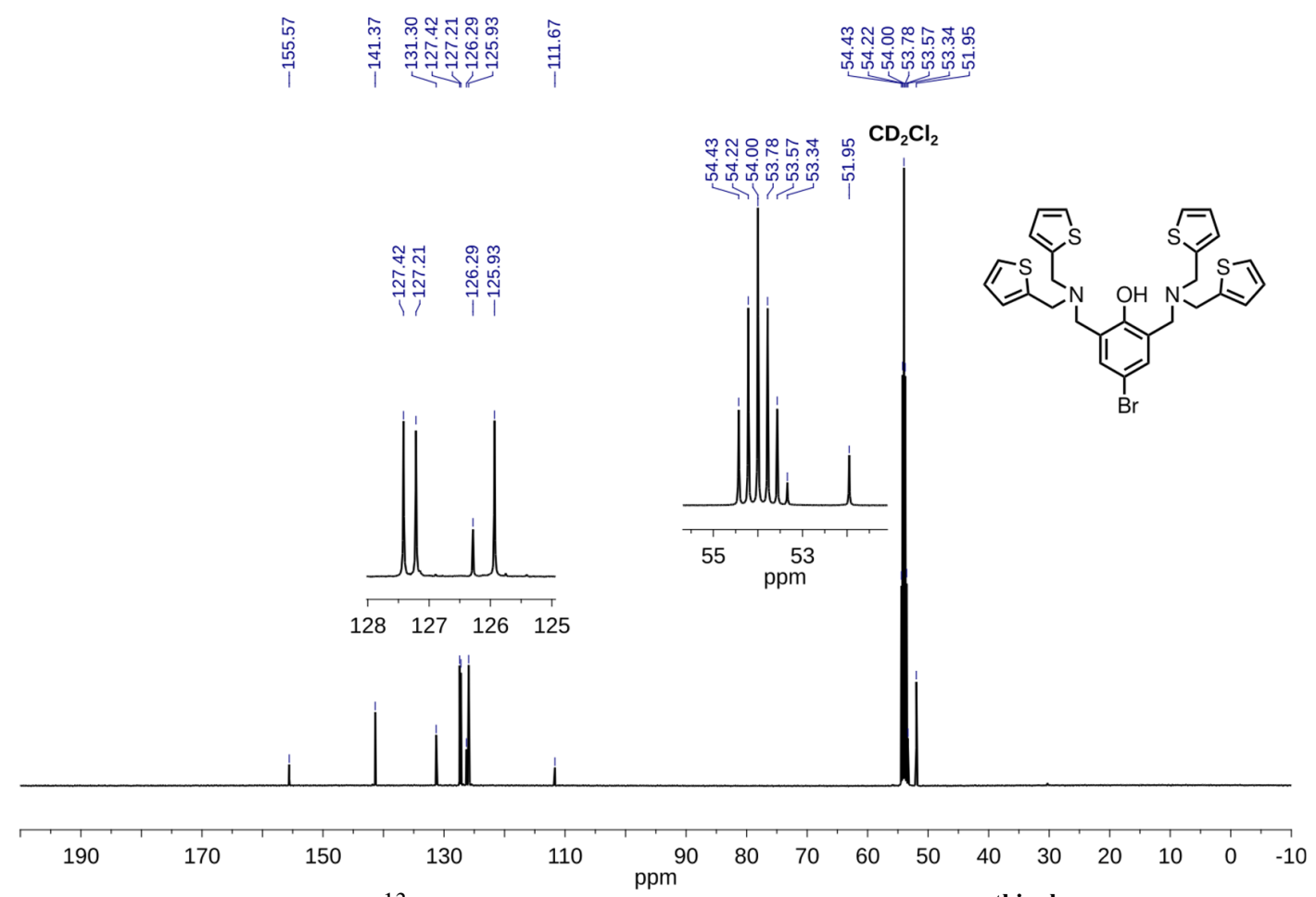

Figure S60: ${ }^{13} \mathrm{C}$ NMR spectrum of thiophen ligand $\mathbf{L}^{\text {thiophen }}-\mathrm{H}$.

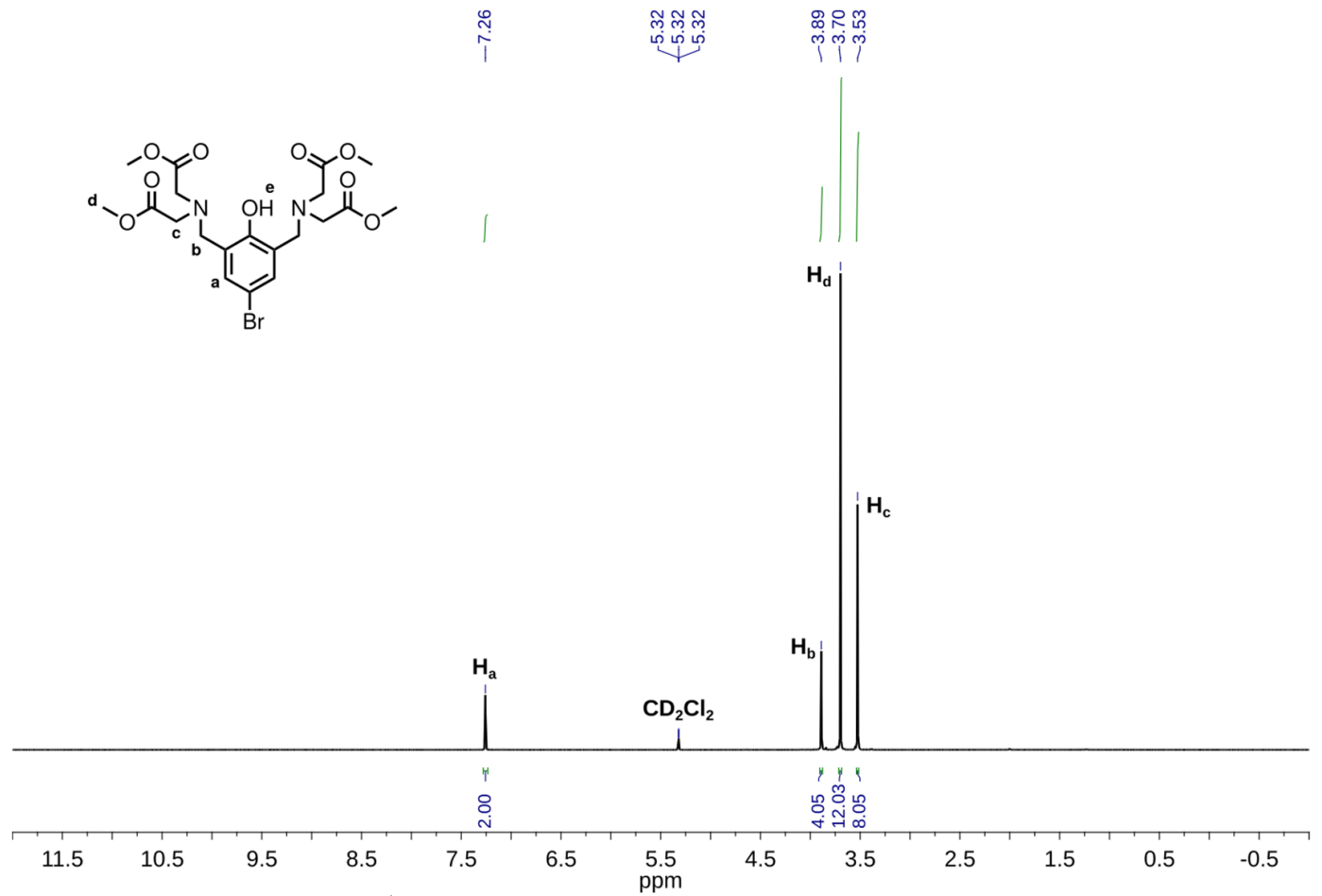

Figure S61: ${ }^{1} \mathrm{H}$ NMR spectrum of methyl ester ligand $\mathbf{L}^{\mathbf{M e}}-\mathrm{H}$. 


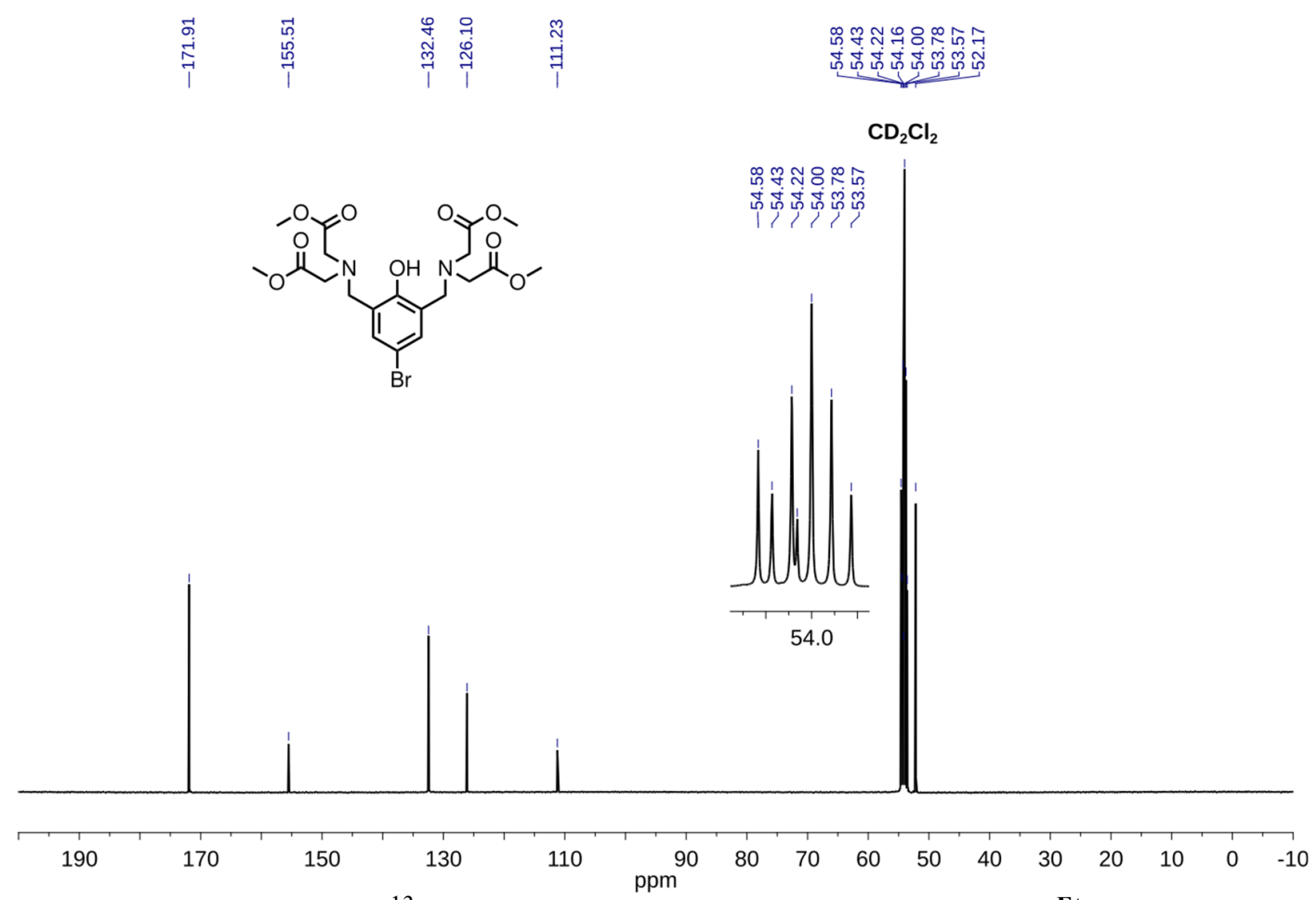

Figure S62: ${ }^{13} \mathrm{C}$ NMR spectrum of methyl ester ligand $\mathbf{L}^{\mathbf{E t}}-\mathrm{H}$.

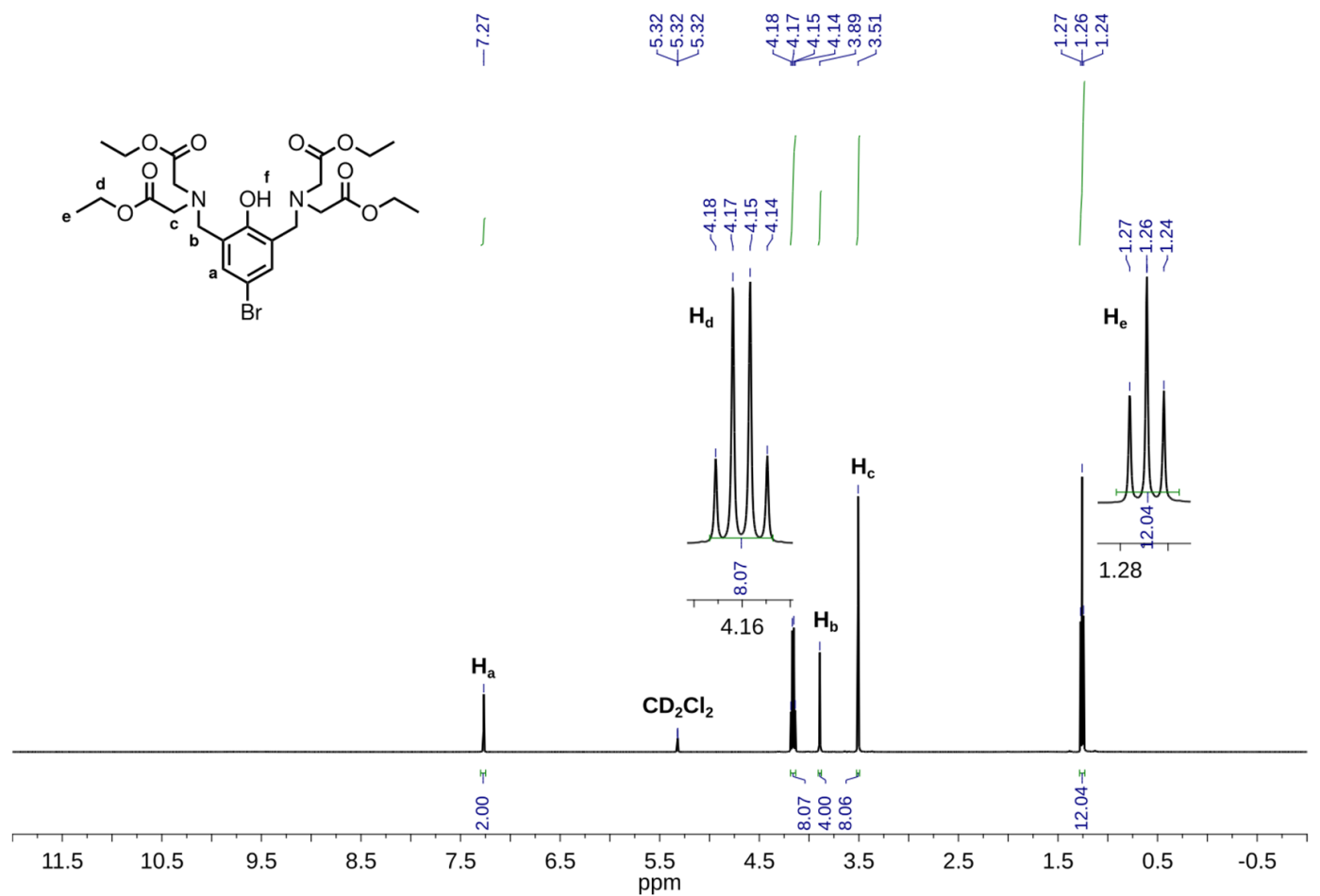

Figure S63: ${ }^{1} \mathrm{H}$ NMR spectrum of ethyl ester ligand $\mathbf{L}^{\mathbf{E t}}-\mathrm{H}$. 


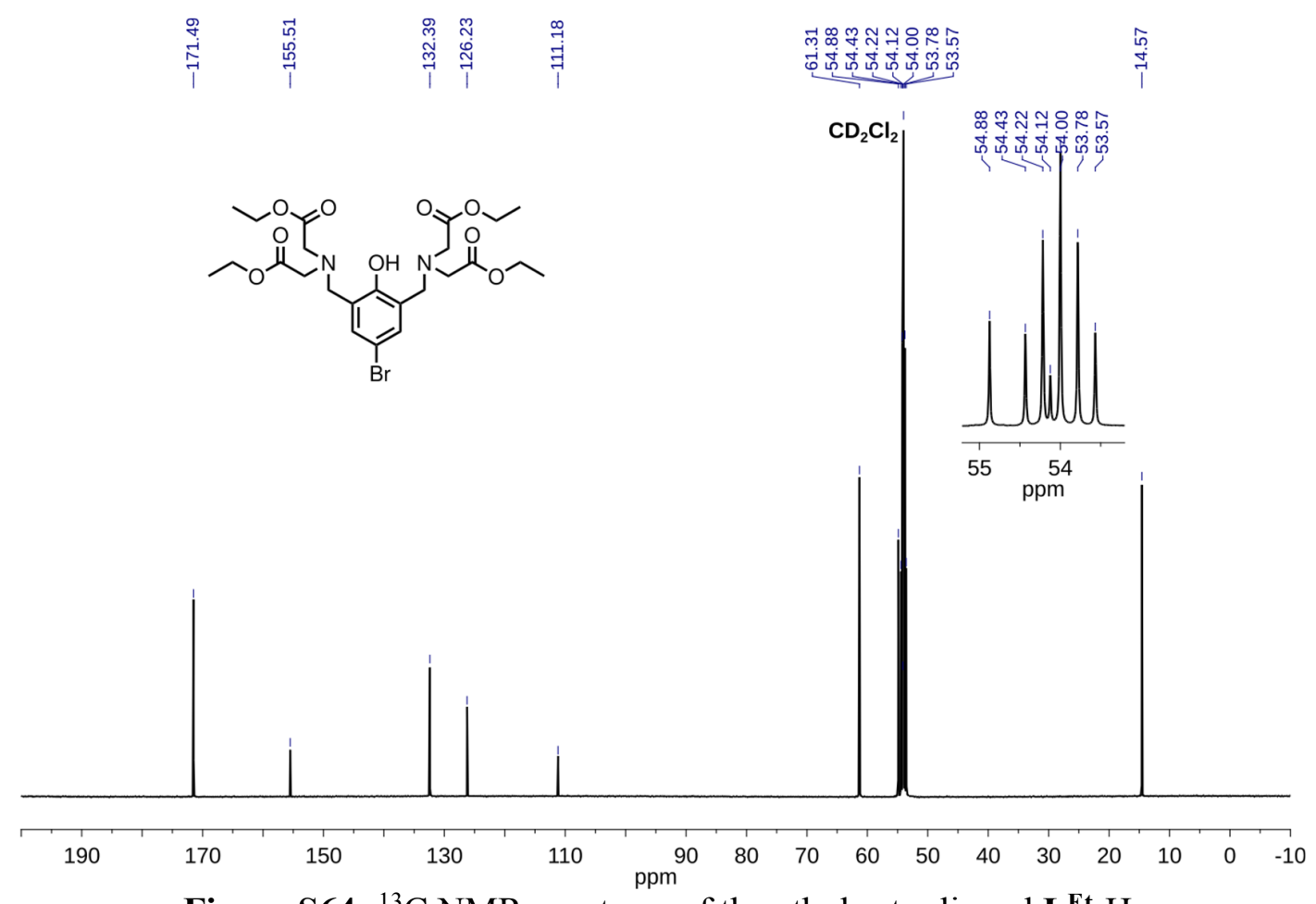

Figure S64: ${ }^{13} \mathrm{C}$ NMR spectrum of the ethyl ester ligand $\mathbf{L}^{\mathbf{E t}}$-H.

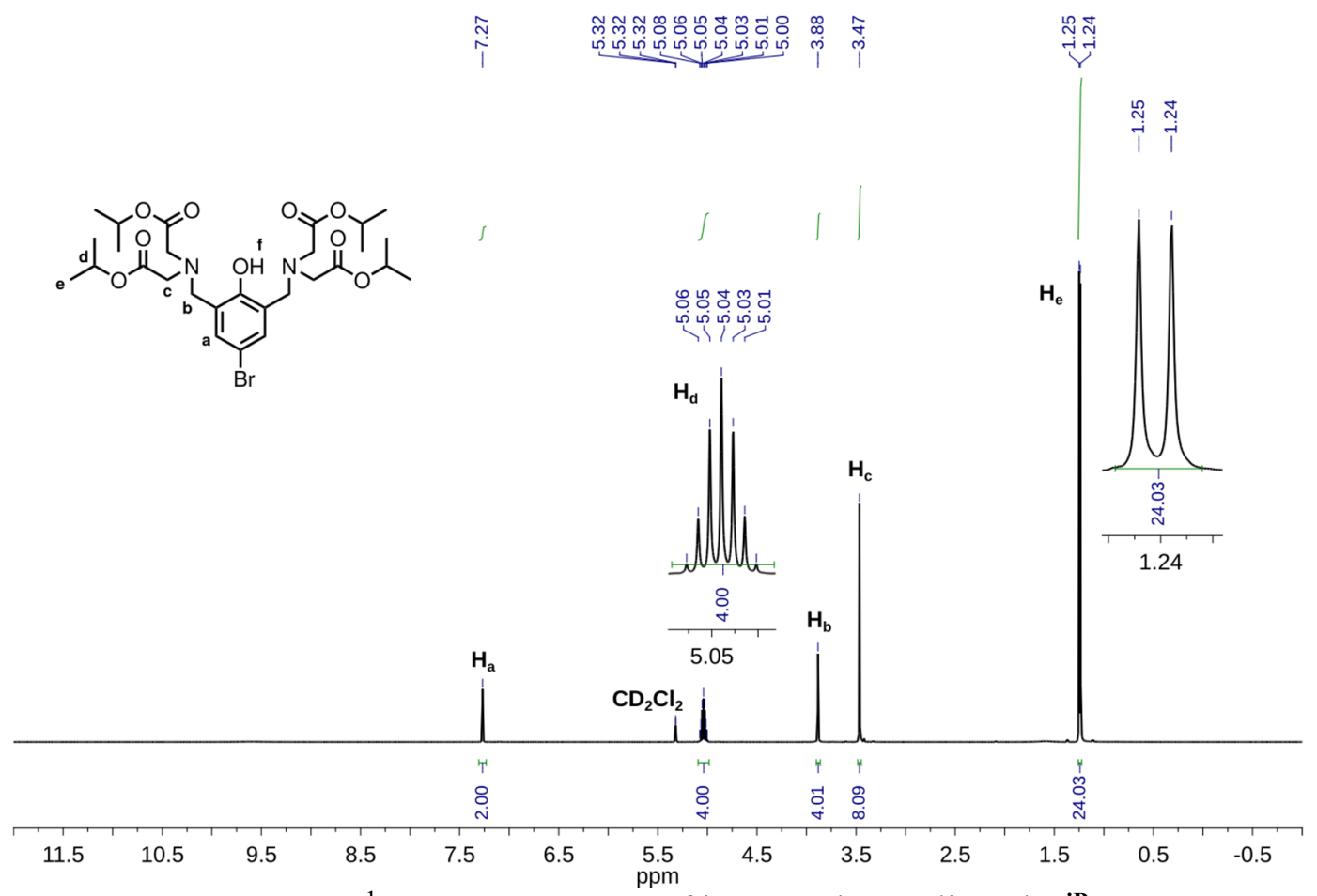

Figure S65: ${ }^{1} \mathrm{H}$ NMR spectrum of isopropyl ester ligand $\mathbf{L}^{\mathrm{iPr}}-\mathrm{H}$. 


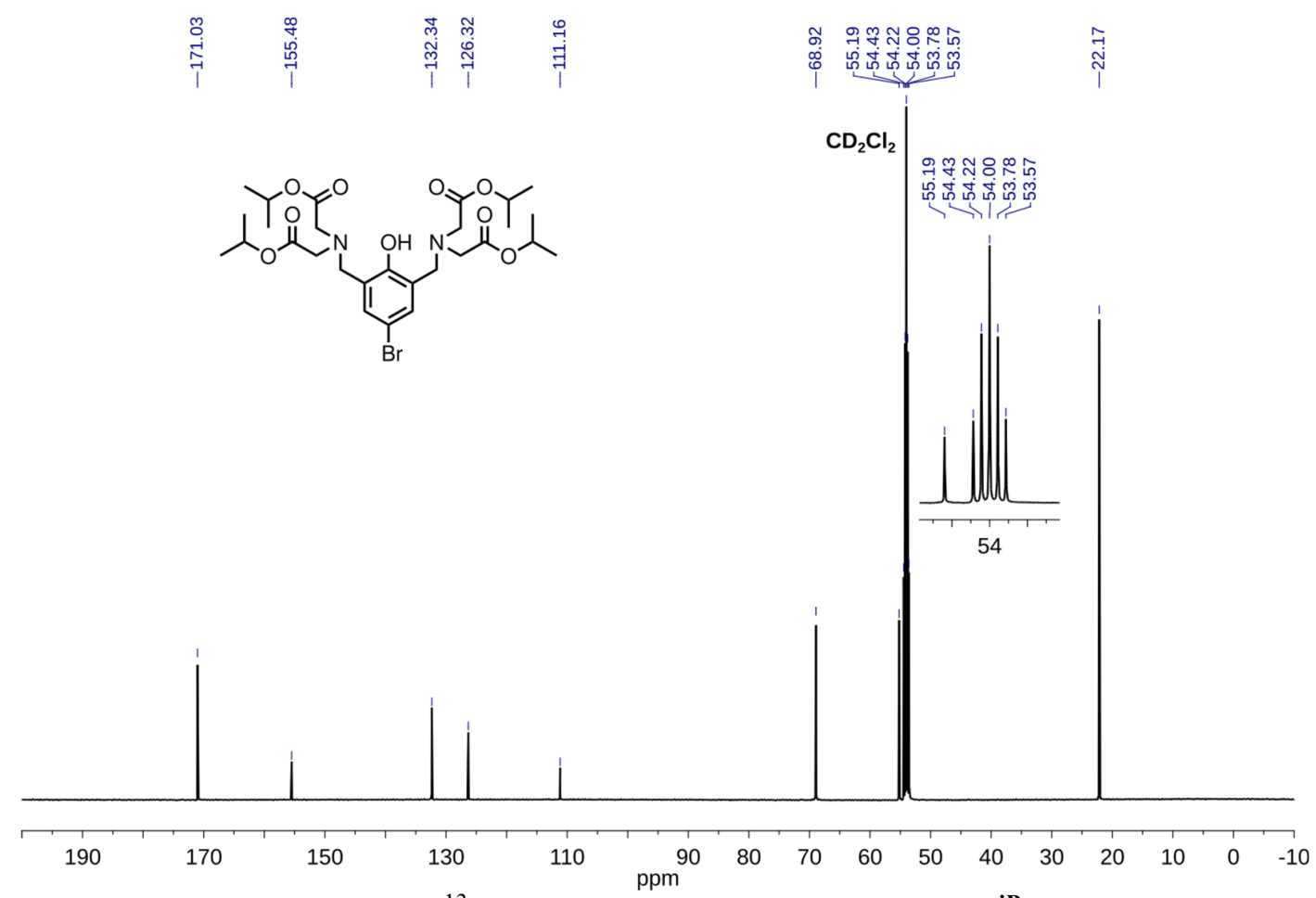

Figure S66: ${ }^{13} \mathrm{C}$ NMR of isopropyl ester ligand $\mathbf{L}^{\mathbf{i P r}}-\mathrm{H}$.

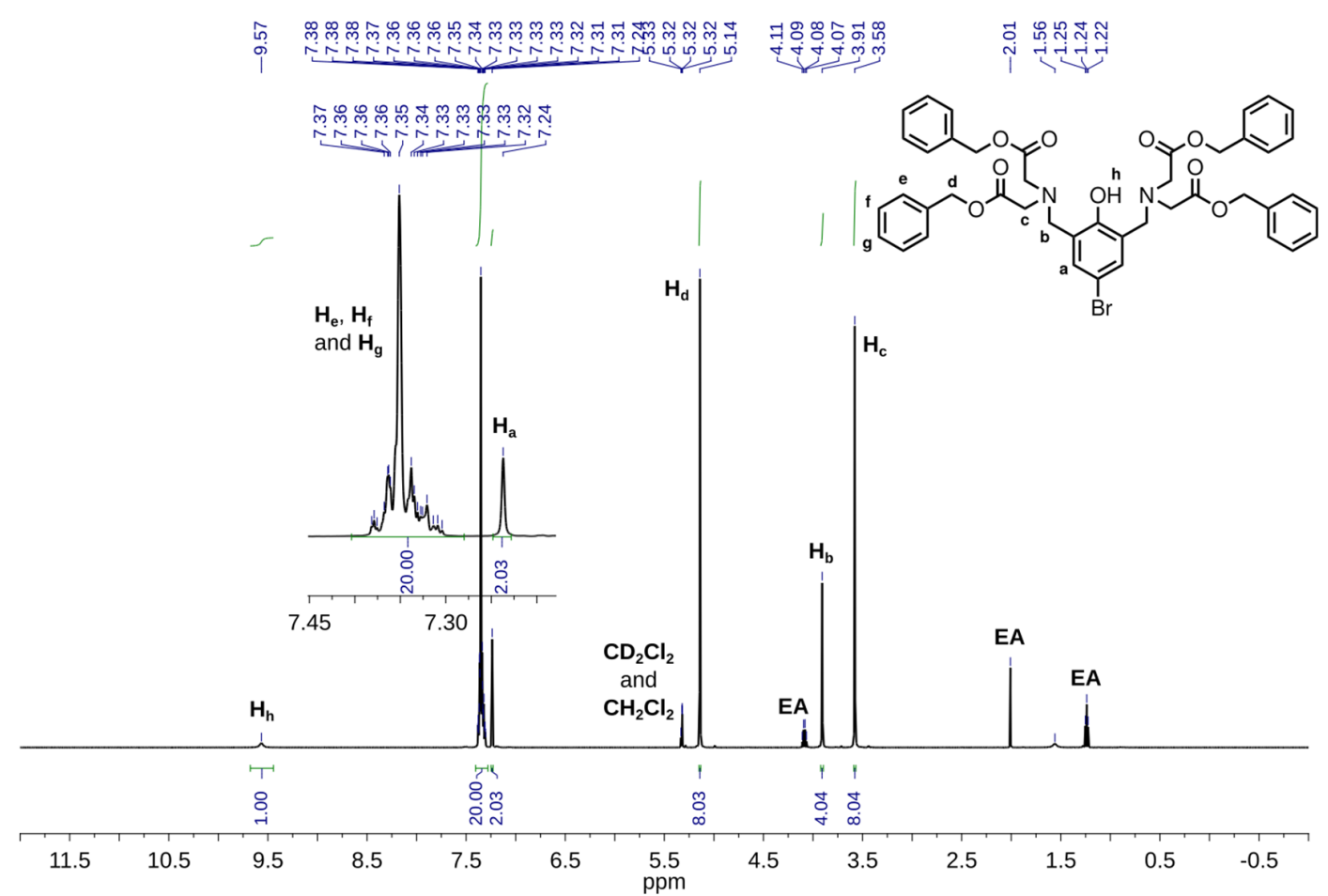

Figure S67: ${ }^{1} \mathrm{H}$ NMR spectrum of benzyl ester ligand $\mathbf{L}^{\mathbf{B z}}-\mathrm{H}$. EA is ethyl acetate. 


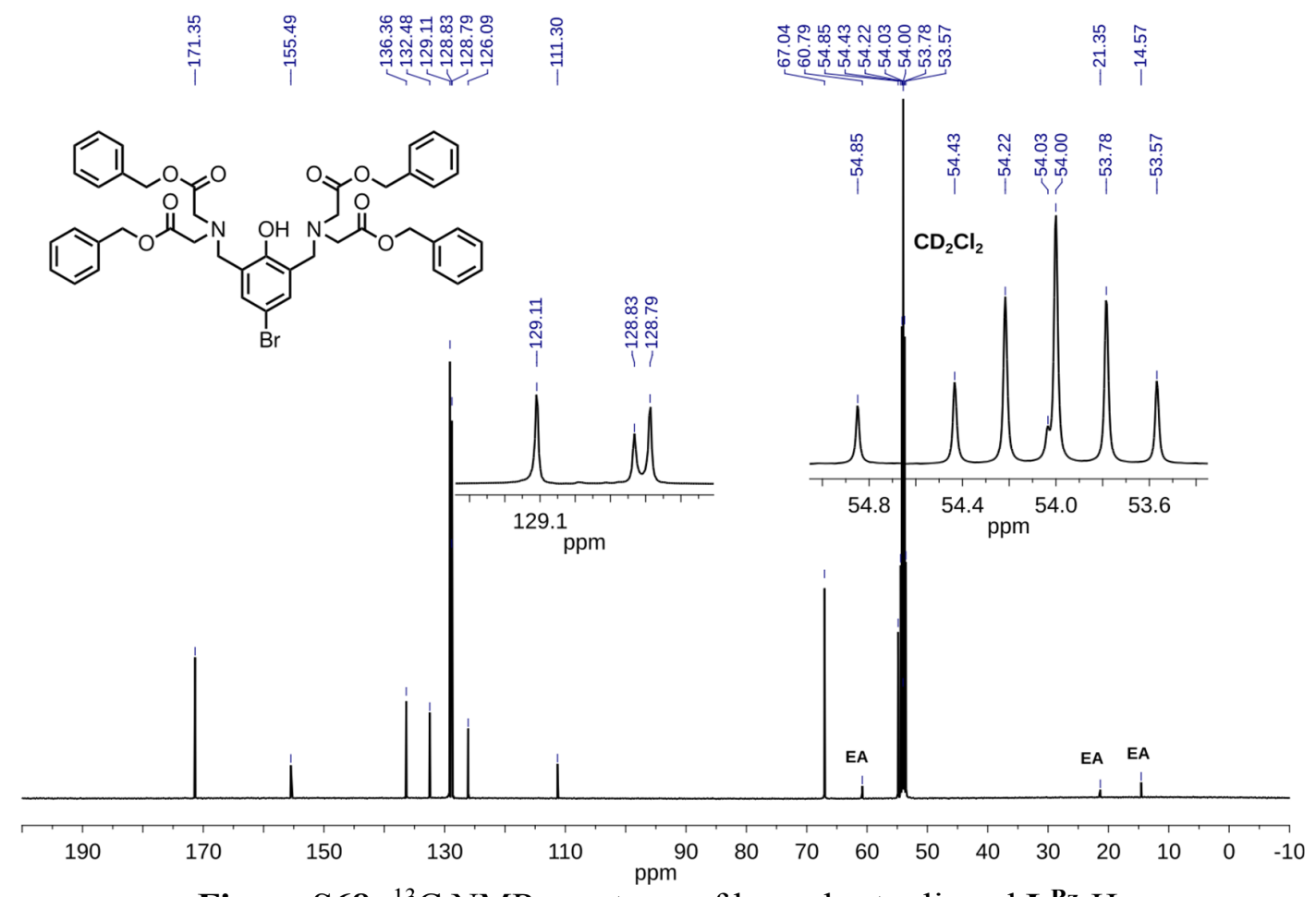

Figure S68: ${ }^{13} \mathrm{C}$ NMR spectrum of benzyl ester ligand $\mathbf{L}^{\mathbf{B z}}-\mathrm{H}$. 


\section{Reports for Crystal Structures}

\subsection{Crystal structure of $\left[\mathrm{L}^{\mathrm{DPA}} \mathrm{Mg}_{2}\left(\mu_{2}-\mathrm{NO}_{3}\right)_{2}\right]\left(\mathrm{NO}_{3}\right)-\mathrm{CCDC} 1972635$}

Single crystals suitable for X-ray diffraction were grown by vapour diffusion of ether into methanol. A colourless crystal (Figure S69, approximate dimensions $0.31 \times 0.16 \times 0.11 \mathrm{~mm}^{3}$ ) was placed onto the tip of a MiTeGen pin and mounted on a Bruker Kappa Duo diffractometer equipped with a ApexII CCD detector at $173 \mathrm{~K}$.

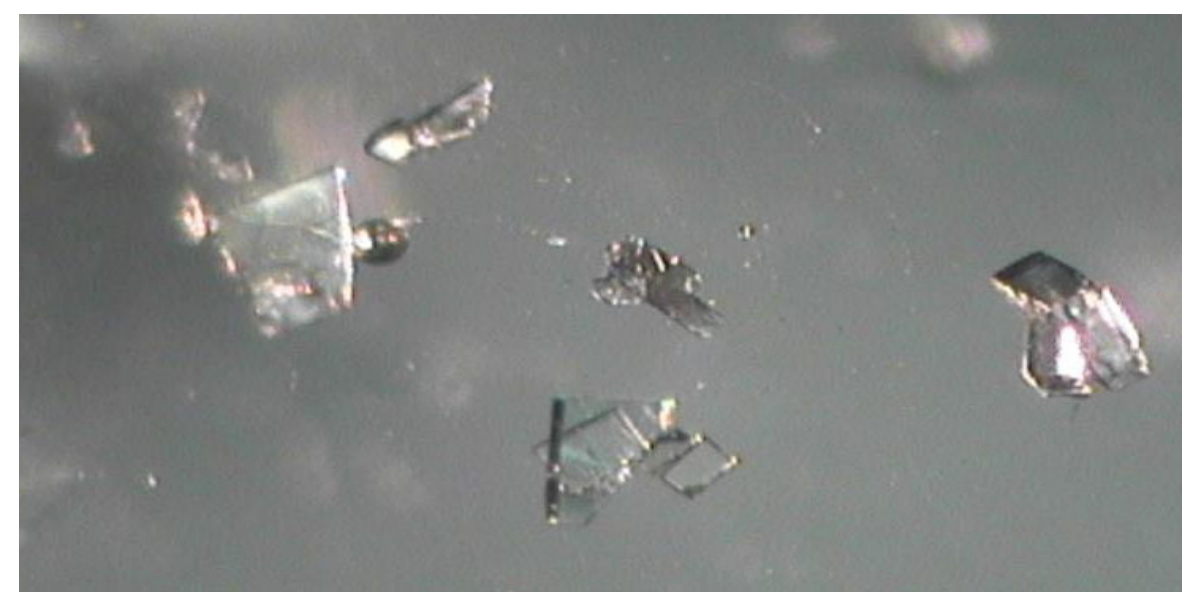

Figure S69: Microscope image of bulk material.

\section{Data collection}

The data collection was carried out using $\mathrm{Cu} K \alpha$ radiation ( $\lambda=1.54178 \AA$, graphite monochromator) with a frame time of 10 seconds and a detector distance of $40 \mathrm{~mm}$. A collection strategy was calculated and complete data to a resolution of $0.84 \AA$ with a redundancy of 10 were collected. The total exposure time was 17.33 hours. The frames were integrated with the Bruker SAINT ${ }^{11}$ software package using a narrowframe algorithm. The integration of the data using an orthorhombic unit cell yielded a total of 73617 reflections to a maximum $\theta$ angle of $66.61^{\circ}(0.84 \AA$ resolution $)$. The final cell constants of $a=17.8785(8)$ $\AA, b=18.7477(8) \AA, c=21.7076(10) \AA$, volume $=7276.0(6) \AA^{3}$, are based upon the refinement of the XYZ-centroids of 9805 reflections above $20 \sigma(\mathrm{I})$ with $7.955^{\circ}<2 \theta<133.2^{\circ}$. Data were corrected for absorption effects using the Multi-Scan method (SADABS). ${ }^{12}$ The ratio of minimum to maximum apparent transmission was 0.851 . Please refer to the following table for additional crystal and refinement information.

\section{Structure solution and refinement}

The space group Pbca was determined based on intensity statistics and systematic absences. The structure was solved using SUPERFLIP ${ }^{13}$ and refined full-matrix least-squares on $\mathrm{F}^{2}$ within the CRYSTALS suite. ${ }^{14}$ A charge-flipping solution was calculated, which provided most non-hydrogen atoms from the E-map. Full-matrix least squares / difference Fourier cycles were performed, which located the remaining 
non-hydrogen atoms. All non-hydrogen atoms were refined with anisotropic displacement parameters. Hydrogen atoms were initially refined with restraints on bond lengths and angles, after which the positions were used as the basis for a riding model. ${ }^{15}$ The final full matrix least squares refinement converged to $\mathrm{R} 1=3.54 \%$ and $\mathrm{wR} 2=8.72 \%$ ( $\mathrm{F}^{2}$, all data). The goodness-of-fit was 1.0220 . On the basis of the final model, the calculated density was $1.5721 .558 \mathrm{~g} / \mathrm{cm}^{3}$ and $\mathrm{F}(000), 3536 \mathrm{e}^{-}$. The remaining electron density is minuscule.

\section{Structure description}

One ligand coordinates two octahedral $\mathrm{Mg}$ atoms through $\mathrm{N}, \mathrm{N}, \mathrm{N}, \mathrm{O}-\mathrm{Mg}$ coordination bonds. The $\mathrm{O}$ atom is located between the two $\mathrm{Mg}$ and coordinates to both. Two $\mathrm{NO}^{-}$are bridging the two $\mathrm{Mg}$ atoms. A methanol molecule is also present in the packing and hydrogen binds to a free NO3-(Figure S70).

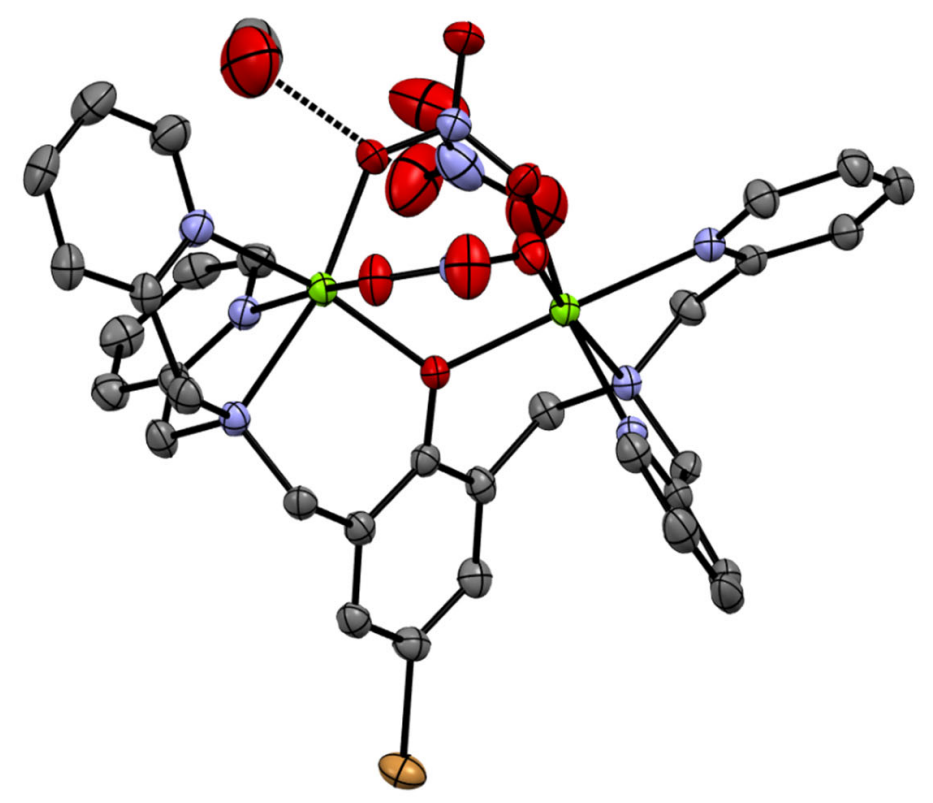

Figure S70: Formula Unit. 


\section{Crystal data and structure refinement}

Empirical formula

Formula weight

Crystal color, shape, size

Temperature

Wavelength

Crystal system, space group

Unit cell dimensions

Volume

Z

Density (calculated)

Absorption coefficient

$\mathrm{F}(000)$

\section{Data collection}

Diffractometer

Theta range for data collection

Index ranges

Reflections collected

Independent reflections

Observed Reflections

Completeness to theta $=66.747^{\circ}$

\section{Solution and Refinement}

Absorption correction

Max. and min. transmission

Solution

Refinement method

Weighting scheme

Data / restraints / parameters

Goodness-of-fit on $\mathrm{F}^{2}$

Final R indices $[\mathrm{I}>2 \sigma(\mathrm{I})]$

$\mathrm{R}$ indices (all data)

Largest diff. peak and hole
C33 H34 Br1 Mg2 N9 O11

861.20

colourless block, $0.31 \times 0.16 \times 0.11 \mathrm{~mm}^{3}$

$173 \mathrm{~K}$

$1.54178 \AA$

Orthorhombic, Pbca

$\mathrm{a}=17.87850(3) \AA$

$\alpha=90^{\circ}$.

$\mathrm{b}=18.74770(3) \AA$

$\beta=90^{\circ}$.

$\mathrm{c}=21.70760(3) \AA$

$\gamma=90^{\circ}$.

$7275.970(19) \AA^{3}$

8

$1.572 \mathrm{Mg} / \mathrm{m}^{3}$

$2.519 \mathrm{~mm}^{-1}$

3536

Kappa Apex II Duo, Bruker

3.977 to $66.747^{\circ}$.

$-21<=\mathrm{h}<=20,-22<=\mathrm{k}<=22,-24<=1<=25$

72907

$6436[$ Rint $=0.031]$

5900

$99.8 \%$

Semi-empirical from equivalents

1.00 and 0.85

Intrinsic methods

Full-matrix least-squares on $\mathrm{F}^{2}$

$\mathrm{w}=\left[\sigma^{2} \mathrm{Fo}^{2}+\mathrm{AP}^{2}+\mathrm{BP}\right]^{-1}$, with

$\mathrm{P}=\left(\mathrm{Fo}^{2}+2 \mathrm{Fc}^{2}\right) / 3, \mathrm{~A}=0.037, \mathrm{~B}=18.94$

$6433 / 2$ / 509

1.0220

$\mathrm{R} 1=0.0354, \mathrm{wR} 2=0.0850$

$\mathrm{R} 1=0.0388, \mathrm{wR} 2=0.0872$

0.82 and -0.53 e. $\AA^{-3}$ 


\subsection{Crystal structure of $\left[\mathrm{L}^{\mathrm{Et}} \mathrm{Mg}_{2}\left(\mathrm{NO}_{3}\right)_{2}\left(\mathrm{H}_{2} \mathrm{O}\right)_{2}\right]\left(\mathrm{NO}_{3}\right)$ - CCDC 1972637}

Single crystals suitable for X-ray diffraction were grown by vapour diffusion of ether into acetonitrile. A colourless crystal (Figure S71, approximate dimensions $0.33 \times 0.23 \times 0.08 \mathrm{~mm}^{3}$ ) was placed onto the tip of a MiTeGen pin and mounted on a Bruker Kappa Duo diffractometer equipped with a ApexII CCD detector at $173 \mathrm{~K}$.

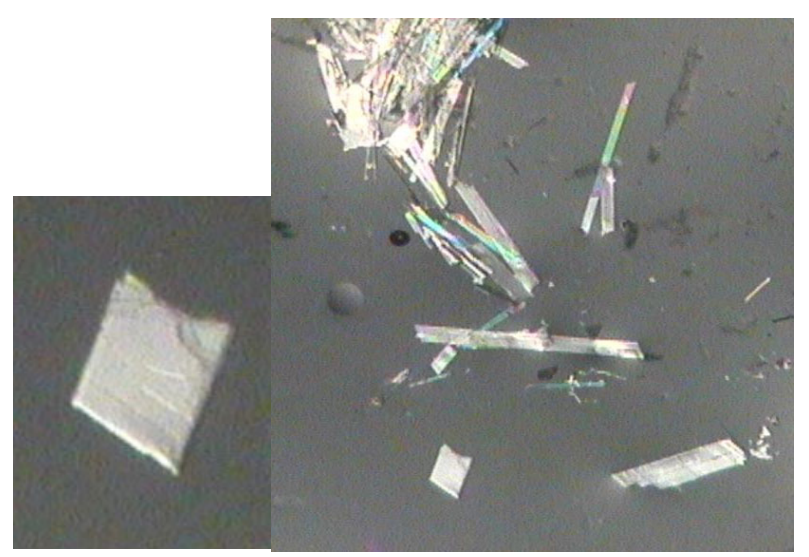

Figure S71: Microscope images of crystal selected and bulk material.

\section{Data collection}

The data collection was carried out using Mo K $\alpha$ radiation $(\lambda=0.71073 \AA$, graphite monochromator) with a frame time of 90 seconds and a detector distance of $60 \mathrm{~mm}$. A collection strategy was calculated and complete data to a resolution of $0.84 \AA$ with a redundancy of 4 were collected. Three major sections of frames were collected with $0.50^{\circ} \omega$ and $\phi$ scans. The total exposure time was 38.89 hours. The frames were integrated with the Bruker SAINT ${ }^{11}$ software package using a narrow-frame algorithm. The integration of the data using a monoclinic unit cell yielded a total of 35671 reflections to a maximum $\theta$ angle of $25.04^{\circ}(0.84 \AA$ resolution), of which 7975 were independent (average redundancy 4.473 , completeness $=98.3 \%$, Rint $=4.80 \%$, Rsig $=4.35 \%)$ and $6714(84.19 \%)$ were greater than $2 \sigma(\mathrm{F} 2)$. The final cell constants of $\mathrm{a}=13.701(3) \AA, \mathrm{b}=23.816(6) \AA, \mathrm{c}=15.527(4) \AA, \beta=115.155(5)^{\circ}$, volume $=$ $4586.0(19) \AA^{3}$, are based upon the refinement of the XYZ-centroids of 9911 reflections above $20 \sigma(\mathrm{I})$ with $5.506^{\circ}<2 \theta<50.05^{\circ}$. Data were corrected for absorption effects using the Multi-Scan method (SADABS). ${ }^{12}$ The ratio of minimum to maximum apparent transmission was 0.778 . The calculated minimum and maximum transmission coefficients (based on crystal size) are 0.7320 and 0.9240 . Please refer to the following table for additional crystal and refinement information.

\section{Structure solution and refinement}

The space group P 1 21/c 1 was determined based on intensity statistics and systematic absences. The structure was solved using SHELXT 2014/5 ${ }^{16-17}$ and refined using full-matrix least-squares on $\mathrm{F}^{2}$ within the OLEX2 suite. ${ }^{18}$ An intrinsic phasing solution was calculated, which provided most non-hydrogen atoms from the E-map. Full-matrix least squares / difference Fourier cycles were performed, which 
located the remaining non-hydrogen atoms. All non-hydrogen atoms were refined with anisotropic displacement parameters. The hydrogen atoms were placed in ideal positions and refined as riding atoms with relative isotropic displacement parameters. The final full matrix least squares refinement converged to $\mathrm{R} 1=0.0791$ and $\mathrm{wR} 2=0.1995\left(\mathrm{~F}^{2}\right.$, all data). The goodness-of-fit was 1.134 . On the basis of the final model, the calculated density was $1.452 \mathrm{~g} / \mathrm{cm}^{3}$ and $\mathrm{F}(000), 2100 \mathrm{e}$. The remaining electron density is located next to the bromine atom, probably due to Fourier series termination error. Disorder on a terminal methyl group was modelled by splitting the occupancy of the $-\mathrm{CH}_{3}$ between two parts.

\section{Structure description}

The structure is a Mg complex with two seven-coordinate metal centers, coordinated to one epta-dentated chelating ligand, two $\mathrm{NO}_{3}$, and two $\mathrm{H}_{2} \mathrm{O}$ molecules. Two diethylether molecules, a water molecule with half occupancy and $\mathrm{A} \mathrm{NO}_{3}{ }^{-}$anion are present in the asymmetric unit. Figure S72 shows the molecular structure of the complex with labelling for etheroatoms. Solvent and hydrogen atoms are omitted for clarity. Figure S73 shows the asymmetric unit. 


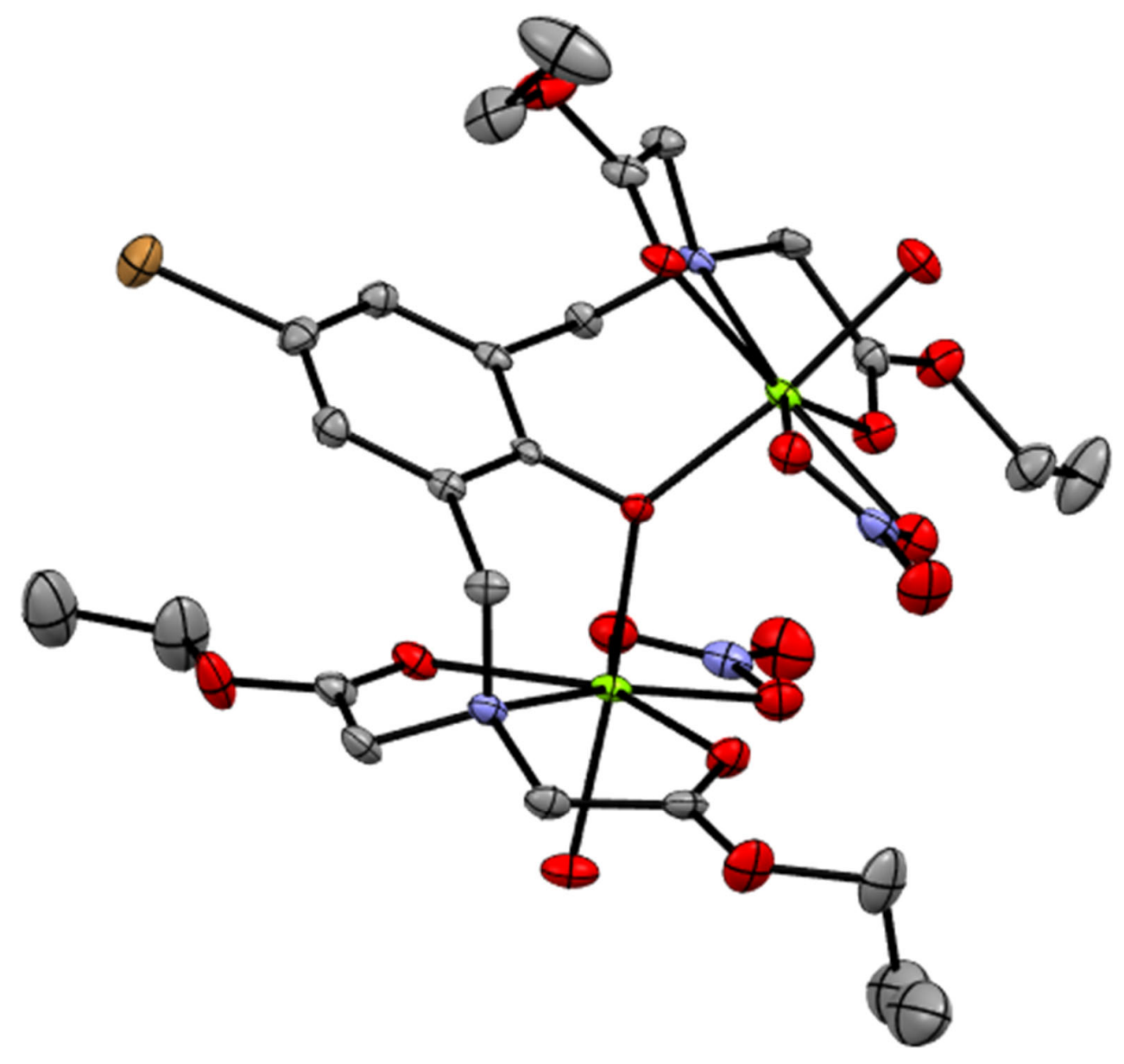

Figure S72: Molecular structure of the complex. Ellipsoids are plotted at the 50\% probability level. Solvent and hydrogen atoms are omitted for clarity. 


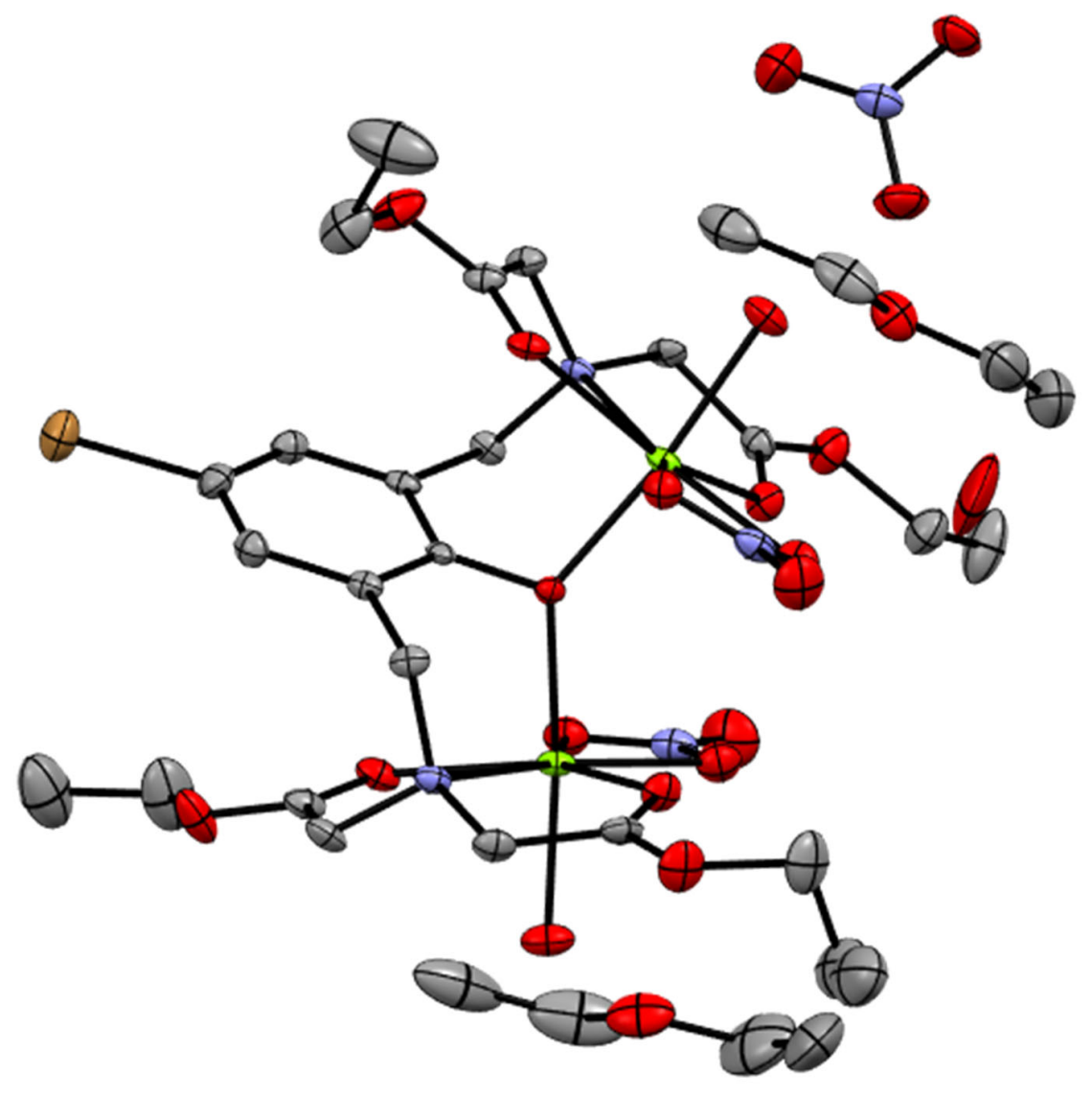

Figure S73: Asymmetric unit.

65 


\section{Crystal data and structure refinement}

Empirical formula

Formula weight

Crystal color, shape, size

Temperature

Wavelength

Crystal system, space group

Unit cell dimensions

Volume

Z

Density (calculated)

Absorption coefficient

$\mathrm{F}(000)$

\section{Data collection}

Diffractometer

Theta range for data collection

Index ranges

Reflections collected

Independent reflections

Observed Reflections

Completeness to theta $=25.041^{\circ}$

\section{Solution and Refinement}

Absorption correction

Max. and min. transmission

Solution

Refinement method

Weighting scheme

Data / restraints / parameters

Goodness-of-fit on $\mathrm{F}^{2}$

Final R indices $[\mathrm{I}>2 \sigma(\mathrm{I})]$

$\mathrm{R}$ indices (all data)

Extinction coefficient

Largest diff. peak and hole
C32 H59 Br Mg2 N5 O22.50

1002.37

colourless plate, $0.33 \times 0.23 \times 0.08 \mathrm{~mm}^{3}$

$173 \mathrm{~K}$

$0.71073 \AA$

Monoclinic, P 1 21/c 1

$\begin{array}{ll}\mathrm{a}=13.701(3) \AA & \alpha=90^{\circ} . \\ \mathrm{b}=23.816(6) \AA & \beta=115.155(5)^{\circ} . \\ \mathrm{c}=15.527(4) \AA & \gamma=90^{\circ} .\end{array}$

4585.9(19) $\AA^{3}$

4

$1.452 \mathrm{~g} / \mathrm{cm}^{3}$

$1.009 \mathrm{~mm}^{-1}$

2100

Kappa Apex II Duo, Bruker

1.682 to $25.041^{\circ}$.

$-10<=\mathrm{h}<=16,-27<=\mathrm{k}<=28,-18<=1<=15$

35671

$7975[$ Rint $=0.0480]$

6714

$98.3 \%$

Semi-empirical from equivalents

0.7452 and 0.5797

Intrinsic methods

Full-matrix least-squares on $\mathrm{F}^{2}$

$\mathrm{w}=\left[\sigma^{2} \mathrm{Fo}^{2}+\mathrm{AP}^{2}+\mathrm{BP}\right]^{-1}$, with

$\mathrm{P}=\left(\mathrm{Fo}^{2}+2 \mathrm{Fc}^{2}\right) / 3, \mathrm{~A}=0.0595, \mathrm{~B}=33.3546$

7975 / 652 / 586

1.134

$\mathrm{R} 1=0.0791, \mathrm{wR} 2=0.1918$

$\mathrm{R} 1=0.0933, \mathrm{wR} 2=0.1995$

$\mathrm{n} / \mathrm{a}$

2.184 and -0.807 e. $\AA^{-3}$ 


\subsection{Crystal structure of $\left[\mathrm{L}^{\mathrm{DPA}} \mathrm{Mg}_{2}\left(\mu_{2}-\mathrm{OAc}\right)_{2}\right]\left(\mathrm{NO}_{3}\right)-\mathrm{CCDC} 1972636$}

Single crystals suitable for X-ray diffraction were grown by vapour diffusion of ether into acetonitrile. A colourless crystal (Figure S74, plate, approximate dimensions $0.43 \times 0.33 \times 0.1 \mathrm{~mm}^{3}$ ) was placed onto the tip of a MiTeGen pin and mounted on a Bruker Kappa Duo diffractometer equipped with a ApexII CCD detector at $173.0 \mathrm{~K}$.

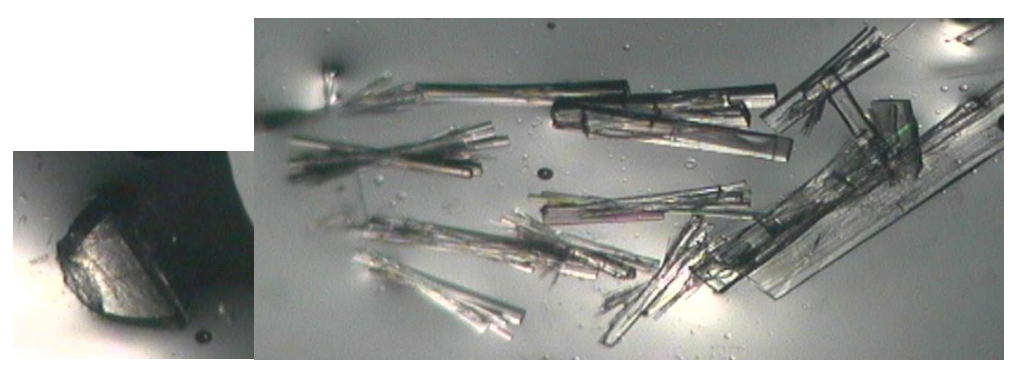

Figure S74: Microscope images of crystal selected and bulk material.

\section{Data collection}

The data collection was carried out using Mo K $\alpha$ radiation $(\lambda=0.71073 \AA$, graphite monochromator $)$ with a frame time of 60 seconds and a detector distance of $50 \mathrm{~mm}$. A collection strategy was calculated and complete data to a resolution of $0.80 \AA$ with a redundancy of 4 were collected. Three sets of frames were collected with $0.50^{\circ} \omega$ and $\phi$ scans. The total exposure time was 18.31 hours. The frames were integrated with the Bruker SAINT ${ }^{11}$ software package using a narrow-frame algorithm. The integration of the data using a monoclinic unit cell yielded a total of 13912 reflections to a maximum $\theta$ angle of $25.43^{\circ}(0.83 \AA$ resolution), of which 7165 were independent (average redundancy 1.942, completeness $=97.6 \%$, Rint $=8.01 \%$, Rsig $=9.22 \%)$ and $4868(67.94 \%)$ were greater than $2 \sigma(\mathrm{F} 2)$. The final cell constants of $\mathrm{a}=10.2468(8) \AA, \mathrm{b}=13.4502(11) \AA, \mathrm{c}=28.727(2) \AA, \beta=90.166(3)^{\circ}$, volume $=3959.2(5)$ $\AA 3$, are based upon the refinement of the XYZ-centroids of 7283 reflections above $20 \sigma(\mathrm{I})$ with $5.222^{\circ}$ $<2 \theta<50.50^{\circ}$. Data were corrected for absorption effects using the Multi-Scan method (SADABS). ${ }^{12}$ The ratio of minimum to maximum apparent transmission was 0.752 . The calculated minimum and maximum transmission coefficients (based on crystal size) are 0.6420 and 0.8950 . Please refer to the following table for additional crystal and refinement information.

\section{Structure solution and refinement}

The space group P 1 21/c 1 was determined based on intensity statistics and systematic absences. The structure was solved using SHELXT 2014/5 $5^{16-17}$ and refined using full-matrix least-squares on $\mathrm{F}^{2}$ within the OLEX2 suite. ${ }^{18}$ An intrinsic phasing solution was calculated, which provided most non-hydrogen atoms from the E-map. Full-matrix least squares / difference Fourier cycles were performed, which located the remaining non-hydrogen atoms. All non-hydrogen atoms were refined with anisotropic displacement parameters. The hydrogen atoms were placed in ideal positions and refined as riding atoms with relative isotropic displacement parameters. The final full matrix least squares refinement converged to $\mathrm{R} 1=0.0529$ and $w R 2=0.1534\left(\mathrm{~F}^{2}\right.$, all data $)$. The goodness-of-fit was 1.001 . On the basis of the final 
model, the calculated density was $1.450 \mathrm{~g} / \mathrm{cm}^{3}$ and $\mathrm{F}(000), 1784 \mathrm{e}^{-}$.

\section{Structure description}

The structure is a magnesium dimer (1:2 ratio between ligand and magnesium). Two acetate molecules and one chelating ligand are bridging the two magnesium atoms. $\mathrm{NO}_{3}{ }^{-}$and acetonitrile are present in the packing (Figure S75).
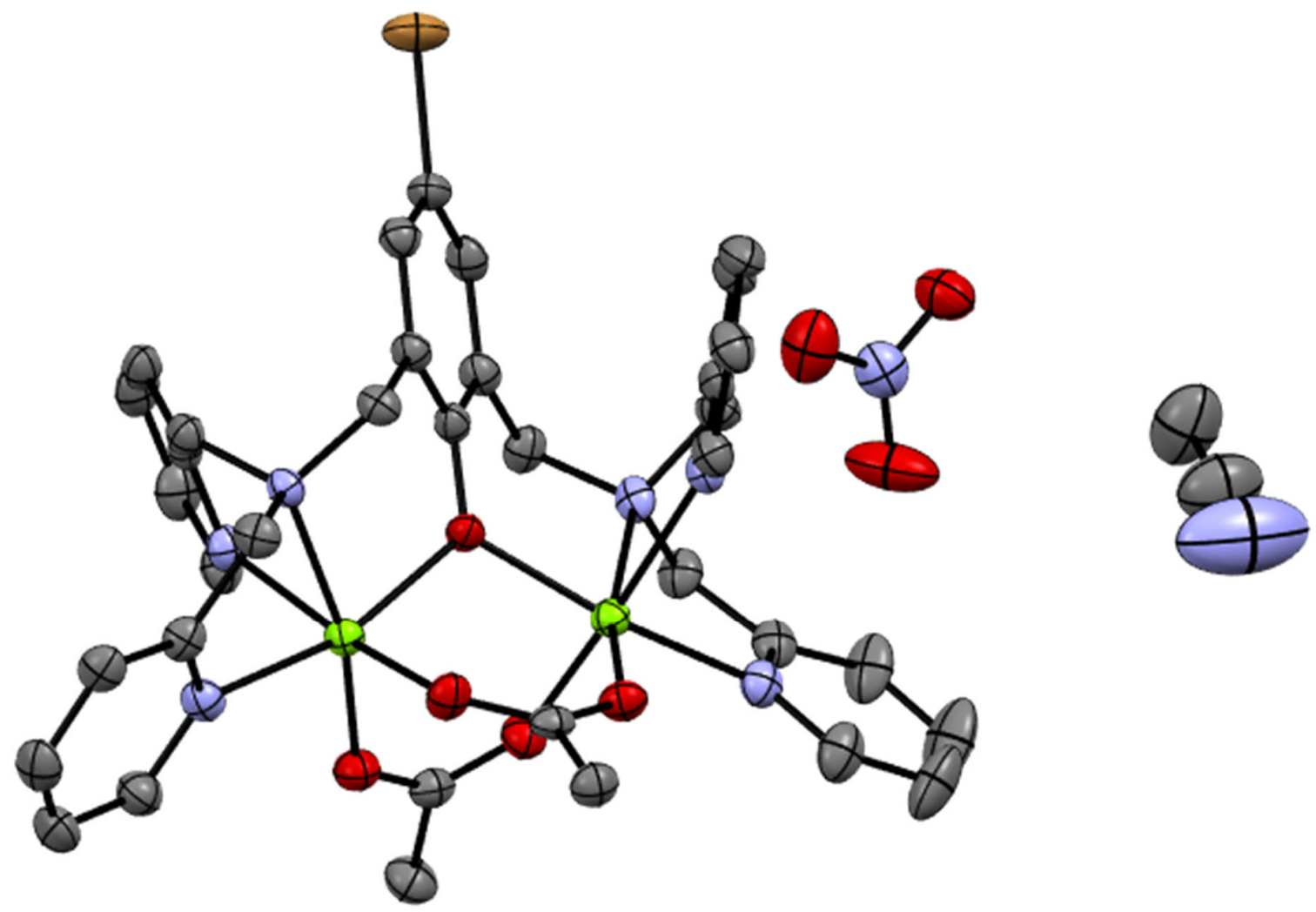

Figure S75: Molecular structure of the complex. Ellipsoids are plotted at the 50\% probability level. Solvent and hydrogen atoms are omitted for clarity. 


\section{Crystal data and structure refinement}

Empirical formula

Formula weight

Crystal color, shape, size

Temperature

Wavelength

Crystal system, space group

Unit cell dimensions

Volume

Z

Density (calculated)

Absorption coefficient

$\mathrm{F}(000)$

\section{Data collection}

Diffractometer

Theta range for data collection

Index ranges

Reflections collected

Independent reflections

Observed Reflections

Completeness to theta $=25.242^{\circ}$

\section{Solution and Refinement}

Absorption correction

Max. and min. transmission

Solution

Refinement method

Weighting scheme

Data / restraints / parameters

Goodness-of-fit on $\mathrm{F}^{2}$

Final R indices $[\mathrm{I}>2 \sigma(\mathrm{I})]$

$\mathrm{R}$ indices (all data)

Extinction coefficient

Largest diff. peak and hole

\section{C38 H39 Br Mg2 N8 O8}

864.30

colourless plate, $0.43 \times 0.33 \times 0.1 \mathrm{~mm}^{3}$

$173.0 \mathrm{~K}$

$0.71073 \AA$

Monoclinic, P 1 21/c 1

$$
\begin{array}{ll}
\mathrm{a}=10.2468(8) \AA & \alpha=90^{\circ} . \\
\mathrm{b}=13.4502(11) \AA & \beta=90.166(3)^{\circ} . \\
\mathrm{c}=28.727(2) \AA & \gamma=90^{\circ} .
\end{array}
$$

3959.2(5) $\AA^{3}$

4

$1.450 \mathrm{~g} / \mathrm{cm}^{3}$

$1.132 \mathrm{~mm}^{-1}$

1784

Bruker APEX-II CCD

1.987 to $25.426^{\circ}$.

$-12<=\mathrm{h}<=12,-16<=\mathrm{k}<=16,0<=\mathrm{l}<=34$

13912

$7165[\operatorname{Rint}=0.0801]$

4868

$99.5 \%$

Semi-empirical from equivalents

0.745159 and 0.559771

Intrinsic methods

Full-matrix least-squares on $\mathrm{F}^{2}$

$\mathrm{w}=\left[\sigma^{2} \mathrm{Fo}^{2}+\mathrm{AP}^{2}+\mathrm{BP}\right]^{-1}$, with

$\mathrm{P}=\left(\mathrm{Fo}^{2}+2 \mathrm{Fc}^{2}\right) / 3, \mathrm{~A}=0.0788, \mathrm{~B}=0.0000$

$7165 / 0 / 517$

1.001

$\mathrm{R} 1=0.0529, \mathrm{wR} 2=0.1307$

$\mathrm{R} 1=0.0821, \mathrm{wR} 2=0.1534$

$\mathrm{n} / \mathrm{a}$

0.908 and -0.460 e. $\AA^{-3}$ 


\section{References}

1. Ingenfeld, B.; Straub, S.; Frömbgen, C.; Lützen, A., Synthesis of Monofunctionalized Calix[5]arenes. Synthesis 2018, 50, 676-684.

2. Lindoy, L. F.; Meehan, G. V.; Svenstrup, N., Mono- and Diformylation of 4-Substituted Phenols: A New Application of the Duff Reaction. Synthesis 1998, 1998, 1029-1032.

3. Daumann, L. J.; Dalle, K. E.; Schenk, G.; McGeary, R. P.; Bernhardt, P. V.; Ollis, D. L.; Gahan, L. R., The role of $\mathrm{Zn}-\mathrm{OR}$ and $\mathrm{Zn}-\mathrm{OH}$ nucleophiles and the influence of para-substituents in the reactions of binuclear phosphatase mimetics. Dalton Trans. 2012, 41, 1695-1708.

4. Roh, J.; Karabanovich, G.; Novakova, V.; Šimůnek, T.; Vávrová, K., Large-Scale Synthesis of Piperazine-2,6-dione and Its Use in the Synthesis of Dexrazoxane Analogues. Synthesis 2016, $48,4580-4588$.

5. Hagemann, J. P.; Kaye, P. T., Novel, Malonyl-Derived Edta Analogues. Synth. Commun. 1997, 27, 2539-2546.

6. Tarn, D.; Xue, M.; Zink, J. I., pH-Responsive Dual Cargo Delivery from Mesoporous Silica Nanoparticles with a Metal-Latched Nanogate. Inorg. Chem. 2013, 52, 2044-2049.

7. Kühn, T.; Schwalbe, H., Monitoring the Kinetics of Ion-Dependent Protein Folding by TimeResolved NMR Spectroscopy at Atomic Resolution. J. Am. Chem. Soc. 2000, 122, 6169-6174.

8. Zhang, L.; Sun, J.; Liu, S.; Cui, X.; Li, W.; Fang, J., Aminoquinoline-based fluorescent probe for detection of $\mathrm{Cu} 2+$ and hydrogen sulfide. Inorg. Chem. Commun. 2013, 35, 311-314.

9. Pathberiya, L. G.; Barlow, N.; Nguyen, T.; Graham, B.; Tuck, K. L., Facile, divergent route to bis-Zn(II)dipicolylamine type chemosensors for pyrophosphate. Tetrahedron 2012, 68, 9435 9439.

10. Kankare, J.; Karppi, A.; Takalo, H., Novel labelling agents for immunoassay by time-resolved electrogenerated chemiluminescence. Anal. Chim. Acta 1994, 295, 27-35.

11. SAINT, Bruker Analytical X-Ray Systems, Madison, WI, current version.

12. SADABS, Bruker Analytical X-Ray Systems, Madison, WI, current version.

13. Palatinus, L.; Chapuis, G., SUPERFLIP. A computer program for the solution of crystal structures by charge flipping in arbitrary dimensions. J. Appl. Crystallogr. 2007, 40 (4), 786790.

14. Betteridge, P. W.; Carruthers, J. R.; Cooper, R. I.; Prout, K.; Watkin, D. J., CRYSTALS version 12: software for guided crystal structure analysis. J. Appl. Crystallogr. 2003, 36 (6), 1487.

15. Cooper, R. I.; Thompson, A. L.; Watkin, D. J., CRYSTALS enhancements: dealing with hydrogen atoms in refinement. J. Appl. Crystallogr. 2010, 43 (5, Pt. 1), 1100-1107.

16. Sheldrick, G. M., A short history of SHELX. Acta Crystallogr., Sect. A: Found. Crystallogr. 2008, 64 (1), 112-122.

17. Sheldrick, G. M., SHELXT - Integrated space-group and crystal-structure determination. Acta Crystallogr., Sect. A: Found. Adv. 2015, 71 (1), 3-8.

18. Dolomanov, O. V.; Bourhis, L. J.; Gildea, R. J.; Howard, J. A. K.; Puschmann, H., OLEX2: a complete structure solution, refinement and analysis program. J. Appl. Crystallogr. 2009, 42 (2), 339-341. 